INSTITUTO DE PESQUISAS ENERGÉTICAS E NUCLEARES

AUTARQUIA ASSOCIADA À UNIVERSIDADE DE SÃO PAULO

\title{
PROCESSO ALTERNATIVO PARA OBTENÇÃO DE TETRAFLUORETO DE URÂNIO A PARTIR DE EFLUENTES \\ FLUORETADOS DA ETAPA DE RECONVERSÃO DE URÂNIO
}

João Batista da Silva Neto

Dissertação apresentada como parte dos requisitos para obtenção do Grau de Mestre em Ciências na Área de Tecnologia Nuclear - Materiais.

Orientador:

Dr. Humberto Gracher Riella 
дे

minha esposa Sueli e aos meus filhos Beatriz, Felipe e Fernando. 


\section{AGRADECIMENTOS}

Ao Dr. Humberto Gracher Riella pela orientação, apoio e paciência na execução deste trabalho.

Ao IPEN-CNEN/SP na pessoa do Dr. Nilson Dias Vieira Junior pela oportunidade oferecida.

Ao curso de Pós - graduação do IPEN-CNEN/SP na presença do Dr. José Carlos Bressiani, pelo dedicado trabalho do corpo docente.

Às secretárias da Pós - graduação do IPEN-CNEN/SP, IIze Cristina Puglia, Maria de Rosário T. Ferreira, Vera Lúcia Mariano Garcia e Ana Maria Pimentel Maiorino, pela presteza nas informações e documentos solicitados.

A Dra. Elita Fontenele Urano de Carvalho, gerente do Centro do Combustível Nuclear - CCN do IPEN - CNEN /SP, pela presteza em me disponibilizar tempo, ambiente e apoio na conciliação das atividades rotineiras e de pesquisa durante a realização deste trabalho.

Ao MSc Reginaldo Pereira Gomes, como primeiro incentivador e idealizador deste trabalho.

Ao Dr. Fábio Branco Vaz de Oliveira, em especial, pela paciência e apoio sempre presentes.

Aos colegas e amigos do Centro do Combustível Nuclear do IPEN - CNEN /SP, seja pela colaboração direta como nos casos dos Técnicos Felipe Bonito Jaldim Ferrufino e Davilson Gomes da Silva, da MSc Gláucia Regina Tanzillo Santos e

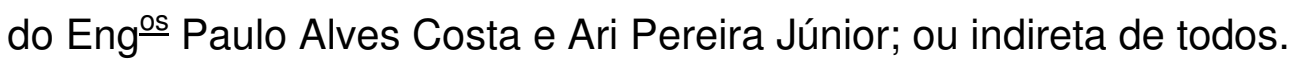


Aos colegas e amigos da Divisão de Processamento Químico do CCN pelo apoio na realização deste trabalho, em particular aos Técnicos Edvaldo Dal Vechio e José Carlos de Carvalho, pelo apoio em determinados momentos, na parte experimental.

Aos colegas e amigos Dra Marycel Elena Barbosa Cotrim, Dra Elizabete Keiko Sonoda Dantas, MSc Cristina Sisti, Cleide Moreira da Silva, Augusta Viana da Silva, Elias Santana da Silveira, Marta Yoshico Maekawa, Nildemar Aparecido Messias Ferreira, Renê Ramos de Oliveira, Celso Vieira de Morais, Marilene Morelli Serna, Dr José Roberto Martinelli e Sandra Maria Cunha, pelo apoio e auxílio na realização das análises de caracterização.

Ao Dr Flávio Machado de Souza Carvalho do Instituto de Geociências da USP, pelo auxílio na interpretação das análises de difração de raios $\mathrm{x}$.

A secretária do CCN, Crstina Oscrovani Leandro, pela disponibildade em estar sempre pronta à colaboração.

À Secretaria da Educação do Estado de São Paulo, por meio da Diretoria de Ensino Regional de Osasco, pela concessão da bolsa de estudos.

A equipe gestora, professores, alunos e funcionários da Escola Estadual "Professor José Jorge", pela amizade e pelo apoio durante a pesquisa.

Aos meus pais, irmãos, esposa e filhos pelo afeto, compreensão e paciência.

Indistintamente aos colegas e amigos pelo incentivo e estímulo. 


\title{
PROCESSO ALTERNATIVO PARA OBTENÇÃO DE TETRAFLUORETO DE URÂNIO A PARTIR DE EFLUENTES FLUORETADOS DA ETAPA DE RECONVERSÃO DE URÂNIO
}

\author{
João Batista da Silva Neto
}

\begin{abstract}
RESUMO
O processamento químico a partir do hexafluoreto de urânio $\left(\mathrm{UF}_{6}\right)$, permite uma flexibilidade na produção de combustíveis à base de siliceto de urânio $\left(\mathrm{U}_{3} \mathrm{Si}_{2}\right)$ e octóxido de urânio $\left(\mathrm{U}_{3} \mathrm{O}_{8}\right)$. Atualmente no IPEN-CNEN/SP desenvolvem-se trabalhos visando o processamento de combustíveis com alta concentração de urânio, por meio da substituição do $\mathrm{U}_{3} \mathrm{O}_{8}$ por $\mathrm{U}_{3} \mathrm{Si}_{2}$. Para a obtenção de $\mathrm{U}_{3} \mathrm{Si}_{2}$, duas possibilidades podem ser consideradas na preparação da matéria-prima utilizada, que é o tetrafluoreto de urânio $\left(\mathrm{UF}_{4}\right)$, são elas: a redução do urânio presente na solução hidrolisada do $\mathrm{UF}_{6}$ utilizando-se cloreto estanhoso $\left(\mathrm{SnCl}_{2}\right)$ e a hidrofluoretação do dióxido de urânio $\left(\mathrm{UO}_{2}\right)$ proveniente do tricarbonato de amônio e uranilo (TCAU).

Descreve-se neste trabalho um procedimento para obtenção de tetrafluoreto de urânio $\left(\mathrm{UF}_{4}\right)$, utilizando-se como matéria-prima os filtrados gerados na preparação de determinados compostos nos processos de reconversão do hexafluoreto de urânio $\left(\mathrm{UF}_{6}\right)$, mais especificamente o amonioperóxidofluoranato (APOFU). Os filtrados consistem principalmente de uma solução contendo altas concentrações dos íons amônio $\left(\mathrm{NH}_{4}^{+}\right)$, fluoreto $\left(\mathrm{F}^{-}\right)$e baixa concentração de urânio.

$\mathrm{O}$ processo descrito visa principalmente a recuperação do $\mathrm{NH}_{4} \mathrm{~F}$ e do urânio, como $\mathrm{UF}_{4}$, por meio da cristalização do bifluoreto de amônio $\left(\mathrm{NH}_{4} \mathrm{HF}_{2}\right)$ e em uma etapa posterior, a adição deste ao $\mathrm{UO}_{2}$, ocorrendo a fluoração e decomposição. $\mathrm{O} \mathrm{UF}_{4}$ obtido foi caracterizado química e fisicamente e será reciclado para ser usado na unidade de produção de urânio metálico para a obtenção de $\mathrm{U}_{3} \mathrm{Si}_{2}$, utilizado como combustível para o reator IEA-R $1_{\mathrm{m}}$.
\end{abstract}




\title{
DRY URANIUM TETRAFLUORIDE PROCESS PREPARATION USING THE URANIUM HEXAFLUORIDE RECONVERSION PROCESS EFFLUENTS.
}

\author{
João Batista da Silva Neto
}

\begin{abstract}
It is a well known fact that the use of uranium tetrafluoride allows flexibility in the production of uranium silicide and uranium oxide fuell. To its obtention there are two conventional routes, the one which reduces uranium from the $\mathrm{UF}_{6}$ hydrolisis solution with stannous chloride, and the hydrofluorination of a solid uranium dioxide. In this work we are introducing a third and a dry way route, mainly utilized to the recovery of uranium from the liquid effluents generated in the uranium hexafluoride reconversion process, at IPEN/CNEN-SP. Working in the liquid phase, this route comprises the recuperation of amonium fluoride by $\mathrm{NH}_{4} \mathrm{HF}_{2}$ precipitacion. Working with the solid residues, the cristalized bifluoride is added to the solid $\mathrm{UO}_{2}$, which comes from the $\mathrm{U}$ miniplates recovery, also to its convertion in a solid state reaction, to obtain $\mathrm{UF}_{4}$. That returns to the process of metallic uranium prodution unity to the $\mathrm{U}_{3} \mathrm{Si}_{2}$ obtention. This fuel is considered in IPENCNEN/SP as the high density fuel phase for IEA-R1m reactor, which will replace the former low density $\mathrm{U}_{3} \mathrm{Si}_{2}-\mathrm{Al}$ fuel.
\end{abstract}




\section{SUMÁRIO}

página

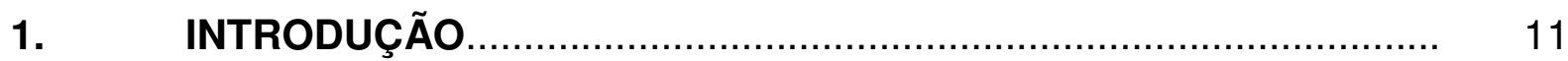

1.1. Questão ambiental............................................................................... 11

1.2. Legislação Ambiental de interesse......................................................... 17

1.3. Normas referentes à efluentes e rejeitos radioativos................................... 20

2. OBJETIVOS .......................................................................... 23

2.1. Objetivos gerais................................................................. 23

2.2. Objetivos específicos...................................................................... 23

3. FUNDAMENTAÇÃO TEÓRICA .................................................... 24

3.1. Aspectos gerais................................................................... 24

3.2. Efluentes fluoretados gerados na etapa de Reconversão de Urânio.. 27

3.2.1. Obtenção de DUA..................................................................... 29

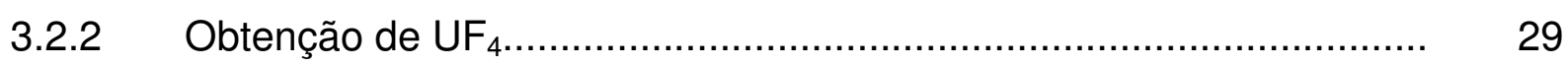

3.2.3. Obtenção de TCAU...................................................................... 30

3.2.4. Obtenção de amonioperoxidofluoranato - APOFU............................ 31

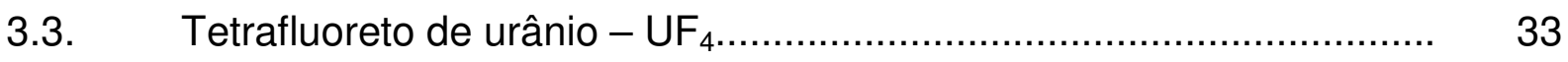

3.3.1. Importância e especificações............................................................. 33

3.3.2. Processos de obtenção de $\mathrm{UF}_{4}$ por via úmida................................... 35

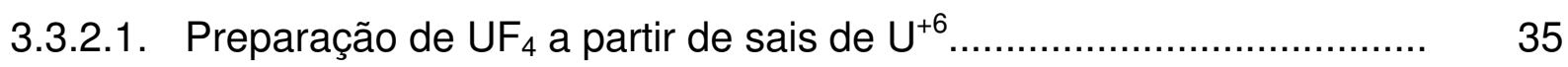

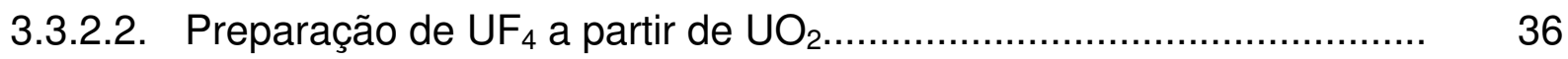

3.3.3. Processos de obtenção de $\mathrm{UF}_{4}$ por via seca.................................... 36

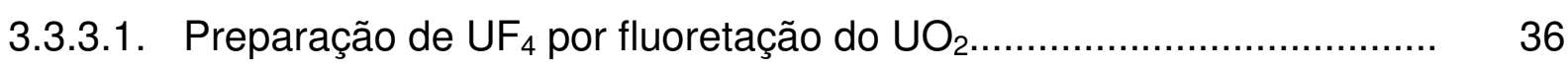

3.3.3.2. Preparação de $\mathrm{UF}_{4}$ por reação do $\mathrm{UO}_{3}$ com $\mathrm{NH}_{3}$ e $\mathrm{HF}$ gasoso........... 36

3.3.3.3. Preparação de $\mathrm{UF}_{4}$ a partir de urânio metálico ou de hidreto de urânio metálico $\left(\mathrm{UH}_{3}\right)$ por fluoretação em altas temperaturas............. 37

3.3.4. Processos de obtenção de $\mathrm{UF}_{4}$ por via seca com bifluoreto de

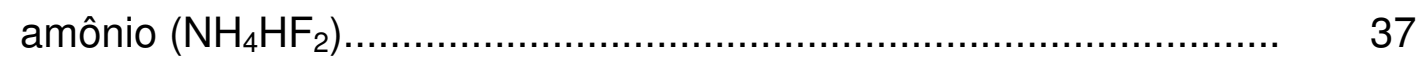

3.3.4.1. Processo da Mallincrodt.................................................................. 37

3.3.4.2. Processo Belga ........................................................................ 39 
3.3.4.3. Preparação de $\mathrm{UF}_{4}$ pela reação de $\mathrm{UO}_{3}$ com bifluoreto de amônio.... 40

4. MATERIAIS E MÉTODOS ..................................................... 42

4.1. Técnicas de Caracterização utilizadas........................................... 42

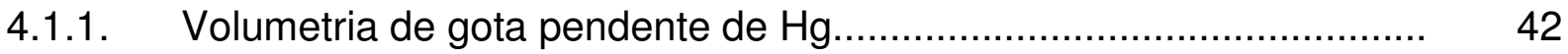

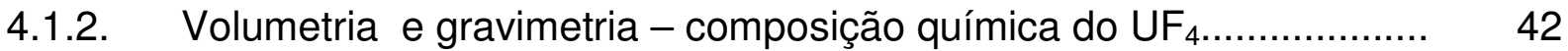

4.1.3. Microdifusão da amônia............................................................... 43

4.1.4. Eletrodo de íon seletivo........................................................ 43

4.1.5. Difração de Raios X................................................................ 44

4.1.6. Microscopia eletrônica de varredura.................................................. 44

4.1.7. $\quad$ Adsorção gasosa (B.E.T.).......................................................... 44

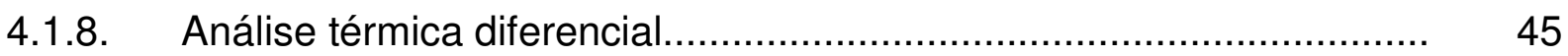

4.1.9. Espalhamento de laser - Distribuição do tamanho de partículas........ 45

4.1.10. Picnometria de Hélio - Determinação da massa específica................ 45

4.1.11. Determinação da densidade......................................................... 46

4.2. Equipamentos................................................................. 47

4.2.1. Reator de cristalização....................................................... 47

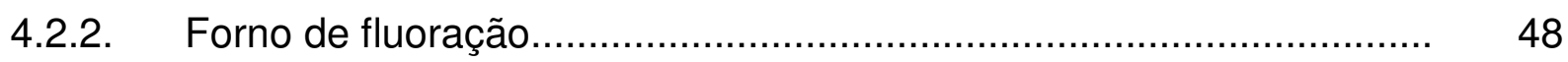

4.2.3. Forno de decomposição....................................................... 48

4.3. Procedimento experimental....................................................... 49

4.3.1. Caracterização química do efluente fluoretado (filtrado VIII).............. 49

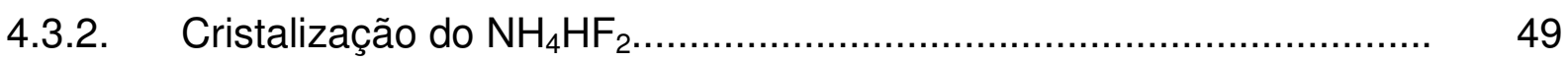

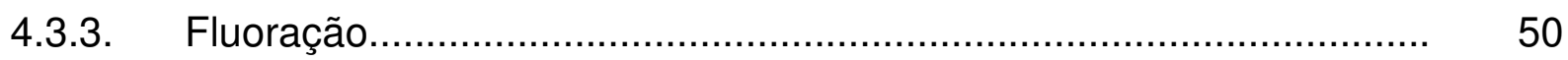

4.3.4 Decomposição....................................................................... 50

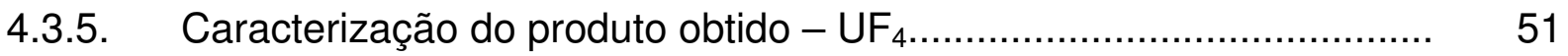

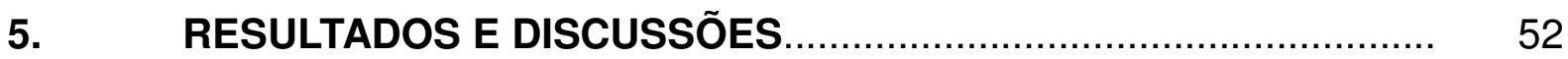

5.1. Caracterização química do efluente fluoretado (filtrado VIII)............... 52

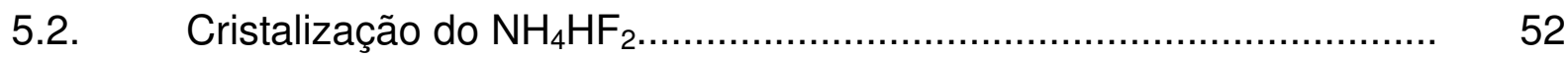

$5.3 \quad$ Fluoração........................................................................... 54

5.4. Decomposição................................................................ 56

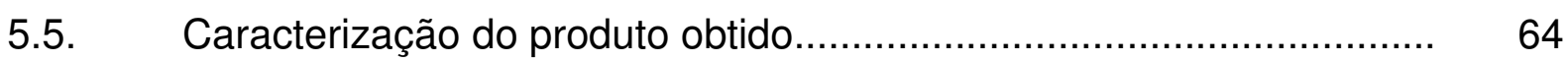

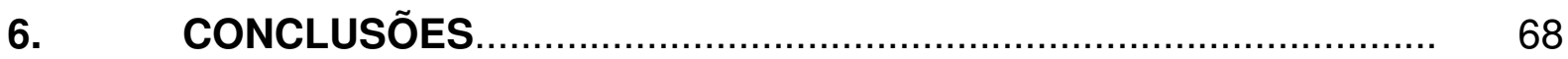

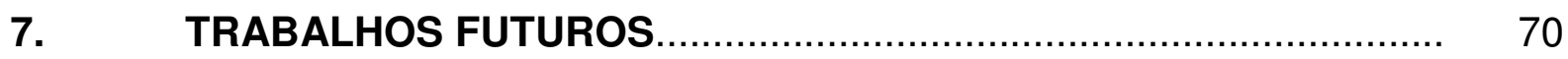

REFERÊNCIAS BIBLIOGRÁFICAS........................................ 71 


\section{TABELAS}

Tabela 01 Valores máximos admissíveis para descarte de efluentes

página

Tabela 02 Composição média do filtrado do DUA..................................... 29

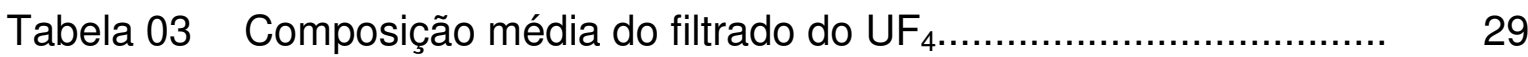

Tabela 04 Composição média do filtrado do TCAU................................... 31

Tabela 05 Composição média do filtrado do APOFU.................................. 32

Tabela 06 Especificações dos limites das principais impurezas em $\mathrm{UF}_{4 \ldots} \quad 34$

Tabela 07 Distribuição do tamanho das partículas recomendada para o $\mathrm{UF}_{4}$

Tabela 08 Resultados obtidos na conversão do $\mathrm{UO}_{2}$ em $\mathrm{UF}_{4}$ pela reação com $\mathrm{NH}_{4} \mathrm{HF}_{2}$, na instalação da Mallincrodt Chemical Works.....

Tabela 09 Programa de aquecimento para a decomposição do $\mathrm{NH}_{4} \mathrm{UF}_{5}$ utilizado pelo Centre d'Etudes pouer lês Applications de l'Energie Nucléaire, na Bélgica................................................. 40

Tabela 10 Composição do filtrado do APOFU utilizado............................ 52

Tabela 11 Ensaios de fluoração e decomposição visando obtenção de $\mathrm{UF}_{4}$ via $\mathrm{U}_{3} \mathrm{O}_{8}$

Tabela 12 Ensaios de fluoração e decomposição visando obtenção de $\mathrm{UF}_{4}$ via $\mathrm{UO}_{2}$

Tabela 13 Ensaios de fluoração e decomposição - sistema aberto - UF via $\mathrm{UO}_{2}$

Tabela 14 Variação da densidade em função das variáveis do processo..

Tabela 15 Características físicas e químicas do $\mathrm{UF}_{4}$

Tabela 16 Impurezas determinadas no $\mathrm{UF}_{4}$ obtido 


\section{Figuras}

Figura 01 Motivações das empresas para proteger o meio ambiente....

página

Figura 02 Razões para a adoção de medidas ambientais

12

Figura 03 Diagrama de blocos dos processos de reconversão do UF $_{6}$ obtendo-se $\mathrm{U}_{3} \mathrm{Si}_{2}$ e $\mathrm{U}_{3} \mathrm{O}_{8}$, via DUA, $\mathrm{UF}_{4}$ e TCAU.

Figura 04 Reator químico com camisa de aquecimento a vapor, revestido em teflon

Figura 05 Forno resistivo Grion para temperaturas até $400{ }^{\circ} \mathrm{C} \ldots \ldots \ldots \ldots . . . . . .48$

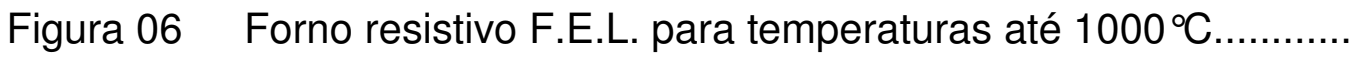

Figura 07 Difratograma de raios $x$ do $\mathrm{NH}_{4} \mathrm{HF}_{2}$ obtido do processamento do filtrado VIII.

Figura 08 Sistema de fluoração

Figura 09 Difratograma de raios $x$, típico do $\left(\mathrm{NH}_{4}\right)_{7} \mathrm{U}_{6} \mathrm{~F}_{31}$ obtido após a fluoração.

Figura 10 Sistema de decomposição...

Figura 11 Difratograma de raios $x$, típico do dióxido de urânio $\left(\mathrm{UO}_{2}\right) \ldots$.

Figura 12 Influência do tempo de fluoração na porcentagem de $\mathrm{UO}_{2}$ não convertido.

Figura 13 Resultados de termogravimetria e análise térmica diferencial, amostras de $\left(\mathrm{NH}_{4}\right)_{7} \mathrm{U}_{6} \mathrm{~F}_{3}$

Figura 14 Difratogramas de raios $x$ do $U_{4}$ via bifluoreto e do $U_{4}$ via aquosa.

Figura 15 Microscopia eletrônica de varredura do UF $_{4}$ obtido via bifluoreto de amônia (a) e pela rota de $\mathrm{SnCl}_{2}$ (b)

Figura 16 Processo proposto para obtenção de UF $_{4}$ a partir do filtrado VIII 


\section{INTRODUÇÃO}

\subsection{Questão ambiental.}

A sociedade começou a se preocupar com a qualidade do meio ambiente após a Segunda Guerra Mundial, com a deterioração e a rápida diminuição de fontes naturais não renováveis decorrentes do grande crescimento econômico e tecnológico da indústria, obtidos em um prazo curto [1].

A questão ambiental é complexa pelo fato dos sistemas ambientais serem irreversíveis por apresentarem estados de desequilíbrio constantes [2].

Os danos ao meio ambiente podem acarretar prejuízos ao futuro da humanidade, a saúde humana pode ser prejudicada, a produtividade econômica pode diminuir e o valor conforto, decorrente de um meio ambiente limpo podem ser perdidos [3].

Sendo assim, a preocupação com o meio ambiente vem crescendo na última década, à medida que a sociedade tem evoluído, problemas tornam-se cruciais e exigem soluções. As soluções destes problemas vêm sendo tomadas pelo poder público em seus códigos e nas demais legislações, muitas vezes exigindo intervenções diretas nos diferentes níveis de governo [4].

Nas duas últimas décadas, as questões citadas anteriormente, têm exercido uma enorme influência nos custos econômicos e, a proteção do meio ambiente tem se tornado um importante campo de atuação para governos, indústrias, grupos sociais e indivíduos [5].

Decorrente desta preocupação, têm sido realizadas conferências internacionais com o intuito de proporcionar a troca de experiências entre os diversos continentes, o que têm conduzido a assinatura de convenções e protocolos internacionais, nos quais, os países signatários se comprometem em cuidar do meio ambiente, criando condições propícias à qualidade de vida de suas populações.

Antes dessa intensa fase regulatória mundial citada anteriormente, as indústrias concentravam suas preocupações exclusivamente com a produção e os 
lucros. Ações para proteger o meio ambiente, neste período, eram insignificantes. Esta despreocupação foi responsável pela ocorrência de comprometimentos ambientais irreversíveis.

A partir deste momento, as empresas passaram a se preocupar com as questões ambientais, assumindo a sua interferência sobre o meio ambiente e, ao mesmo tempo, buscando formas para minimizar os efeitos da poluição.

As atividades industriais de alto impacto ambiental, devido ao elevado grau de risco que originam à saúde das populações e de poluição ambiental, constituem-se em uma preocupação crescente da sociedade e dos órgãos reguladores ambientais.

As motivações das empresas para proteger o meio ambiente são demonstradas na FIG. 1 a seguir [6]:

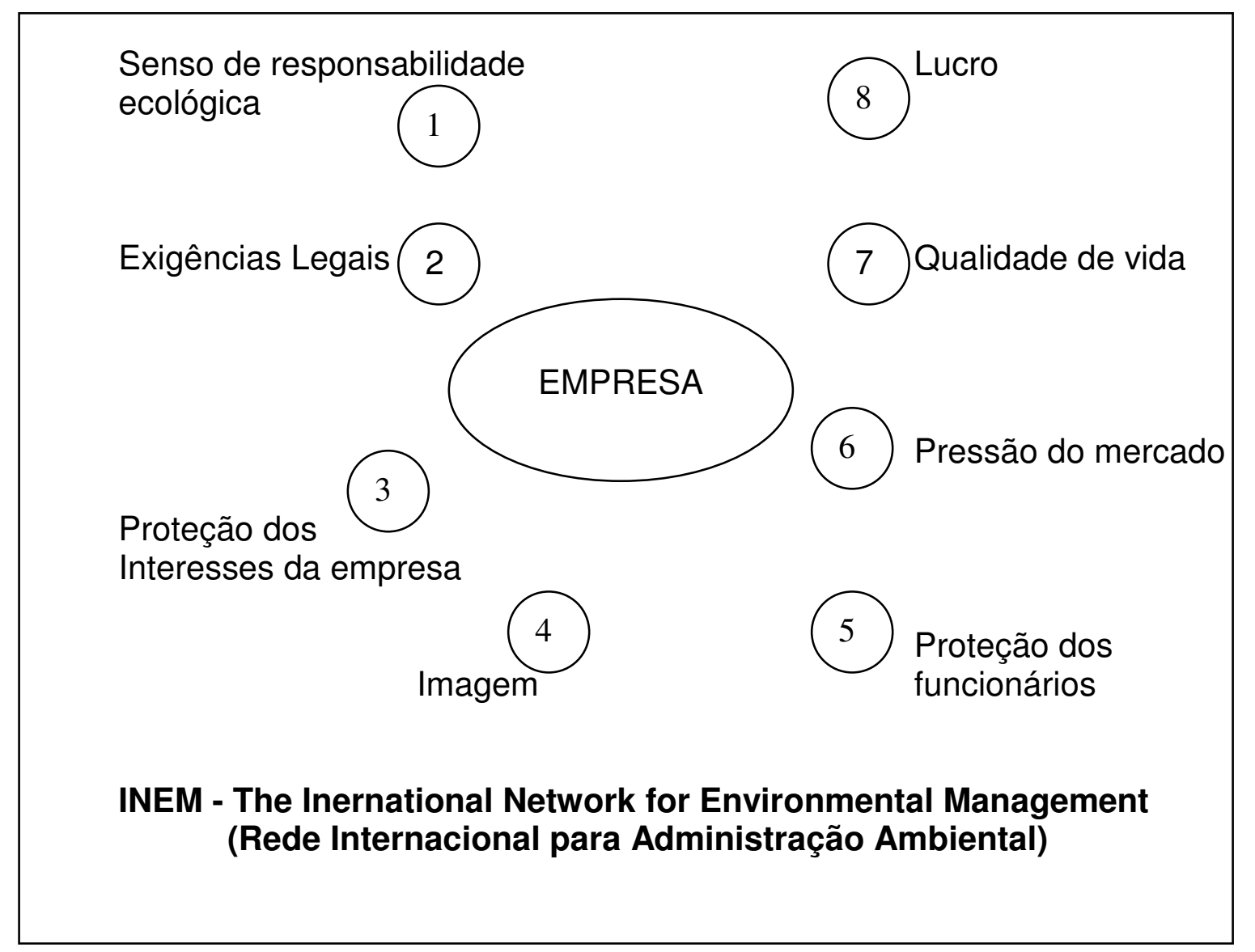

Figura 1: Motivações das empresas para proteger o meio ambiente

As organizações estão reavaliando seu papel perante a sociedade, tendo de assumir um maior envolvimento com o que ocorre a sua volta, seja em 
decorrência do processo produtivo ou através do ciclo de vida de seus produtos [7].

Fica claro que a sociedade voltou-se para preservar o meio ambiente em prol das gerações futuras buscando alternativas para equilibrar a atividade produtiva e econômica.

Com relação aos processos executados atualmente, adotou-se uma nova postura, até então não levada em conta, ou seja: "como os processos afetam o meio ambiente?" A ordem passa a ser: mudar o processo para acabar com o resíduo; agir nas fontes geradoras; minimizar a emissão; valorizar o resíduo para reaproveitá-lo e, só em último caso, tratá-lo e descartá-lo.

As organizações devem tratar a variável ambiental como um aspecto significativo a ser considerado nas suas estratégias [8].

É importante também que as organizações utilizem os custos da qualidade ambiental na avaliação e melhoria da posição de competitividade, com relação aos seus concorrentes [9].

Isso nada mais é do que o Gerenciamento Ambiental do Sistema, que é uma ferramenta fundamental para que a alta administração das empresas possa tomar certas decisões. Ele se origina pelo controle de uma série de atividades que surgem em decorrência da preocupação e comprometimento das organizações com a preservação do meio ambiente.

Dentre estas atividades pode-se citar: formular estratégias de administração do meio ambiente, assegurar que a empresa esteja em conformidade com as leis ambientais, implementar programa de prevenção à poluição, gerir instrumentos de correção de danos ao meio ambiente, adequar os produtos às especificações ecológicas.

Além das atividades já descritas, a organização precisa também se preocupar em administrar o programa ambiental da empresa buscando o desenvolvimento sustentável, a análise do ciclo de vida dos produtos e a questão dos passivos ambientais.

O objetivo maior deste gerenciamento é o de buscar permanente melhoria da qualidade ambiental dos serviços, produtos e ambiente de trabalho de qualquer organização pública ou privada, propiciando inúmeros benefícios, 
dentre os quais destacamos: a melhoria da imagem perante os diversos fatores que interagem com o empreendimento; redução dos custos ambientais; menores riscos de infrações e multas; aumento de produtividade; melhoria da competitividade e surgimento de alternativas tecnológicas inovadoras.

Em outras palavras, o Sistema de Gestão Ambiental serve para a sistematização das medidas ambientais e para a melhoria da eficiência do compromisso ambiental das organizações. A FIG. 2 apresenta as principais razões para a adoção de medidas gerenciais associadas à gestão ambiental pelas industrias[10].

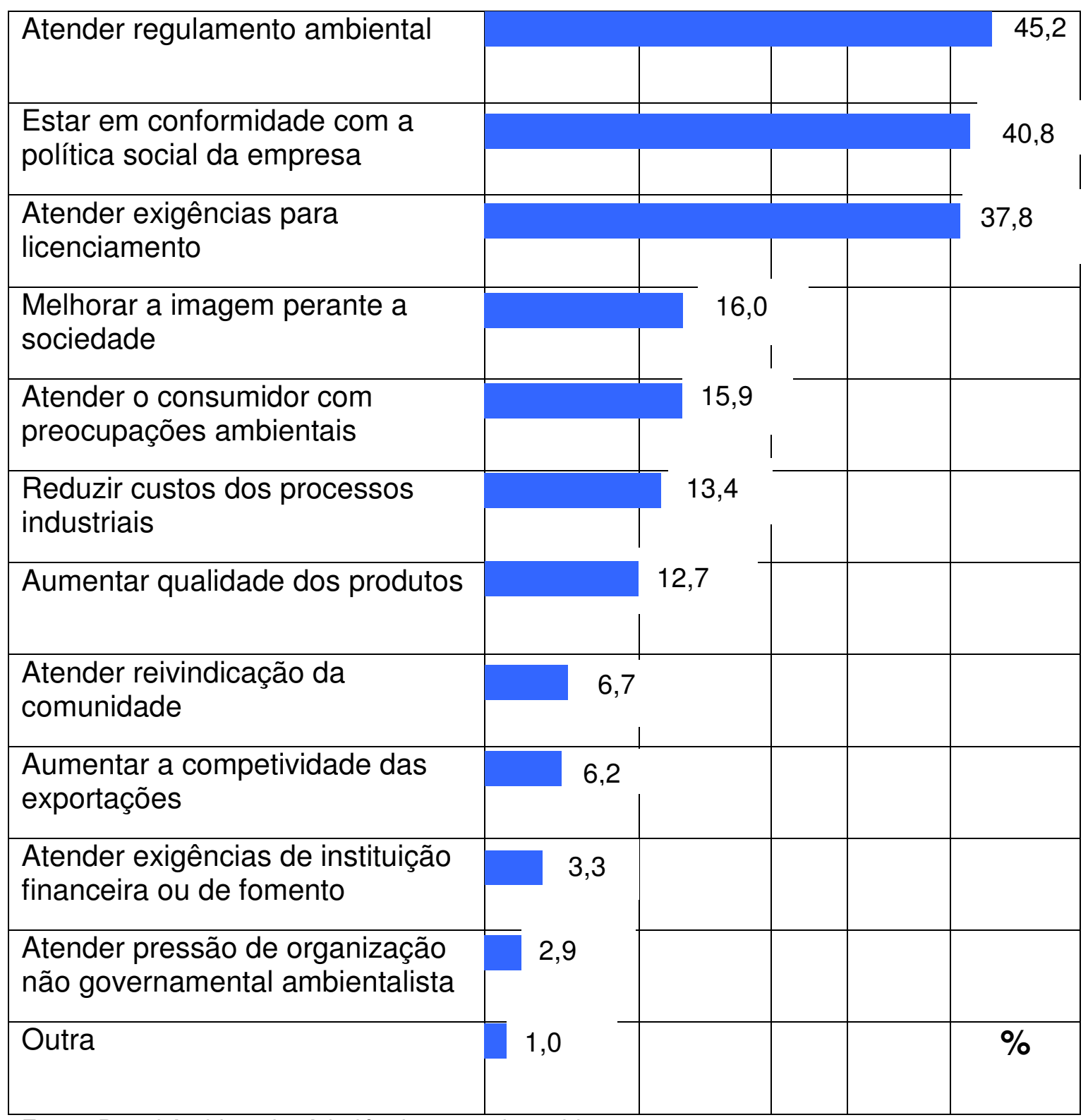

Fonte: Portal Ambiental - A indústria e o meio ambiente.

Figura 2 - Razões para a adoção de medidas ambientais. 
Apesar do Meio Ambiente ser entendido como o conjunto dos recursos naturais e suas inter-relações com seres vivos, é comum este conceito ser associado apenas ao "verde" da paisagem, da natureza ou à vida selvagem. Com isso esquecemos dos recursos hídricos, das questões relativas à poluição do ar, acabamos até relegando a um segundo plano o meio ambiente urbano, que nada mais é que a natureza modificada pelo homem. Chegando mesmo a esquecer que somos parte ativa do meio ambiente em que vivemos [11].

A utilização descontrolada dos recursos naturais renováveis, acrescidas da explosão demográfica, despertou ao longo dos anos uma consciência da necessidade de preservação do meio ambiente.

Durante muitos anos, o desenvolvimento econômico decorrente da Revolução Industrial impediu que os problemas ambientais fossem considerados.

As décadas de 40 e 50 foram marcadas pelo desafio dos aliados na reconstrução após a II Guerra Mundial motivando o estabelecimento de um sistema econômico internacional e a fundação das primeiras associações de proteção ambiental.

A década de 60 evidenciou a preocupação da comunidade internacional com os limites do desenvolvimento do planeta. Nesse período iniciaram as discussões sobre os riscos da degradação do meio ambiente pelo homem. Criou-se nos Estados Unidos a Agência de Proteção Ambiental (EPA).

O termo meio ambiente foi utilizado pela primeira vez na década de 1960 num evento internacional, na reunião do Clube de Roma, que tinha como objetivo a reconstrução dos países no pós-guerra e a discussão sobre os negócios internacionais. Especialistas de diversas áreas e nacionalidades colocaram em discussão a crescente crise do ambiente humano e buscaram soluções para os problemas ambientais.

$\mathrm{Na}$ década de 70 foi criado um mecanismo institucional para tratar das questões ambientais no âmbito das Nações Unidas - Programa das Nações Unidas para o Meio Ambiente (PNUMA).

Daquela época até os dias de hoje houve um grande avanço nas questões ambientais, alimentado pelas informações globalizadas, com a conseqüente conscientização e aprimoramento da legalização ambiental. 
O Brasil através de novas legislações vem buscando proteger o meio ambiente da poluição industrial reconhecendo a necessidade das organizações permanecerem economicamente viáveis [12].

No Brasil, os fatos marcantes na evolução das regulamentações foram: a aprovação da Lei 6.938 da Política Nacional de Meio Ambiente, em 31/08/81.Em 1986 o Conselho Nacional do Meio Ambiente (CONAMA) aprova a Resolução nº 001/86 que estabelece as responsabilidades e critérios básicos e as diretrizes gerais para o uso e implementação da avaliação de impacto ambiental (AIA) como um dos instrumentos da Política Nacional do Meio Ambiente. E a Constituição Federal Brasileira foi promulgada em 5 de outubro de 1988, contendo pela primeira vez um capítulo sobre meio ambiente e vários outros artigos afins.

Esta Lei da Política Nacional do Meio Ambiente foi regulamentada inicialmente pelo Decreto 8.8351 de 01/06/83, posteriormente revogada pelo Decreto 99.274 de 06/06/90, que o substituiu [13].

Esta Lei pode ser considerada um dos marcos mais importantes, senão o mais importante da legislação ambiental brasileira, não apenas por se tratar da primeira norma a cuidar do meio ambiente de uma forma global como pelos inúmeros e significativos avanços e inovações que trouxe para a disciplina da questão ambiental, além de preencher um vazio na legislação há muito sentido em nosso país que até então contava apenas com legislação esparsa sobre a matéria e uma total ausência de definição sobre a política ambiental a ser seguida [13].

Esta lei define poluidor como "a pessoa física ou jurídica, de direito público ou privado, responsável, direta ou indiretamente, por atividade causadora de degradação ambiental" e recursos ambientais como "a atmosfera, as águas interiores, superficiais e subterrâneas, os estuários, o mar territorial, o solo, o subsolo e os elementos da biosfera".

Define também como degradação da qualidade ambiental como "a alteração adversa das características do meio ambiente" e a poluição como a degradação da qualidade ambiental resultante de atividades que direta ou indiretamente:

a) prejudiquem a saúde, segurança e o bem estar da população; 
b) criem condições adversas às atividades sociais e econômicas;

c) afetam desfavoravelmente a biota;

d) afetem as condições estéticas ou sanitárias do meio ambiente;

e) lancem matéria ou energia em desacordo com os padrões ambientais estabelecidos.

Foi através desta Lei que foi criada a Secretaria Especial de Meio Ambiente (SEMA) vinculada ao Ministério do Interior, integrada por um colegiado: o Conselho Nacional do meio Ambiente (CONAMA). Este colegiado é composto por representantes de ministérios e entidades setoriais da Administração Federal, diretamente envolvidos com a questão ambiental, bem como órgãos ambientais estaduais e municipais, de entidades de classe e de ONGs [14].

A Constituição Federal de 1988, em seu artigo 225, parágrafo 3ㄴ, estabelece que: "As condutas e atividades consideradas lesivas ao meio ambiente sujeitarão os infratores, pessoas físicas ou jurídicas, as sanções penais e administrativas, independentemente da obrigação de reparar os danos causados".

Isso significa que a gestão inadequada de resíduos pode levar seus responsáveis ao pagamento de multas e a sanções penais e administrativas. Além disso, o dano causado ao meio ambiente, como poluição de corpos hídricos, contaminação de lençol freático e danos à saúde, devem ser reparados pelos responsáveis. A reparação do dano, na maioria dos casos, é muito mais complicada tecnicamente e envolve muito mais recursos financeiros do que a prevenção, isto é, do que os investimentos técnico-financeiros na gestão adequada [15].

\subsection{Legislação Ambiental de interesse}

Durante muitos anos, o desenvolvimento econômico decorrente da Revolução Industrial impediu que os problemas ambientais fossem considerados. Quando o mundo acordou para a necessidade de regulamentar a ação dos agentes econômicos sobre o meio ambiente, o contexto era muito particular.

A poluição e os impactos ambientais do desenvolvimento desordenado eram visíveis, ou seja, a forma como a sociedade acelerou o seu desenvolvimento em detrimento do planeta e dos seus ecossistemas criou a necessidade de rever 
a utilização dos recursos naturais, pois os benefícios proporcionados pelo progresso eram justificados como um "mal necessário", algo com que deveríamos nos resignar [11].

A comunidade internacional vem publicando nos últimos anos uma enorme quantidade de legislação e vem adotando várias ações, no sentido de melhorar a forma como todos nós lidamos com o ambiente, como resultado das preocupações sobre os danos, a longo prazo, nos oceanos e atmosfera, bem como na degradação dos solos,

Diversos estudos demonstram que a legislação, além de ser um importante instrumento de controle e fiscalização das atividades industriais, contribui para a melhoria da gestão das empresas, inclusive para a implantação de medidas que resultam em proteção ambiental.

A legislação ambiental é muito complexa e têm como objetivo assegurar a qualidade do meio ambiente, bem como garantir a proteção da saúde das populações.

$\mathrm{Na}$ esteira do que vem ocorrendo no mundo todo, em nosso País este fenômeno é claramente identificado no plano legislativo, em que se viu a construção, nos últimos anos, de verdadeiro arsenal jurídico para a proteção de nossos recursos ambientais.

As Constituições brasileiras anteriormente a 1988 eram totalmente omissas com relação ao meio ambiente. Não cuidavam da matéria, quer direta, quer indiretamente e mesmo ao tratar dos recursos naturais o faz com vistas ao seu aproveitamento econômico.

O marco representado pela Política Nacional do Meio Ambiente seguido pela inovadora Constituição Federal de 1988, que dedica capítulo específico ao tema, quebrando tradicionais dogmas do Direito pátrio e consagrando princípios ambientais fundamentais, colocou a temática ambiental brasileira, sob o aspecto formal, entre as mais evoluídas do planeta [16].

A Constituição Federal aborda amplamente a matéria dedicando todo um capítulo à proteção ambiental, além de promover uma acentuada descentralização no que respeita a competência, tanto para legislar como para adotar ações administrativas com vista à proteção do meio ambiente [13]. 
Conhecer e difundir a legislação ambiental consiste em uma poderosa arma para o sucesso do processo [17].

Se no mundo, a preocupação com os direitos da população cresceu vertiginosamente a partir da década de 60, bem como legislações ambientais visando a prevenção e ao controle da poluição têm sido introduzidos nos últimos 40 anos. No Brasil não foi diferente, o estado de São Paulo deu o passo inicial, promulgando em 1976, a Lei no $997 / 76$ e o seu regulamento, aprovado pelo decreto $\mathrm{n}^{0}$ 8468/76 (Cetesb, 1984), voltados exatamente para a prevenção e o controle da poluição das águas, do solo e do ar.

No âmbito federal, a principal norma adotada é a Constituição Federal de 1988, onde são apresentadas todas as diretrizes relativas ao meio ambiente [18]. Contudo, em função dos interesses diversos da sociedade, tornou-se necessária a criação de normas complementares visando restringir e disciplinar a utilização dos recursos naturais.

$\mathrm{Na}$ esfera federal, entre as principais normas que tratam da questão do meio ambiente destaca-se a Lei $n \stackrel{0}{6} 938$, de 31 de agosto de 1981, que estabelece a Política Nacional do Meio Ambiente, com base nos incisos VI e VII do artigo 23 e 235 da Constituição Federal e o Sisnama. Nesta norma são estabelecidos os critérios básicos relativos à questão ambiental e são criados órgãos de assessoria, com o objetivo de implantar a Política Nacional do Meio Ambiente.

No que se refere ao estabelecimento de normas e padrões de qualidade compatíveis com o meio ambiente ecologicamente equilibrado e essencial à sadia qualidade de vida, foi criado o Conselho Nacional do Meio Ambiente - CONAMA, que é o órgão responsável pela especificação dos parâmetros para lançamento de poluentes no ar, solo e nas águas, este atribui aos órgãos estaduais a responsabilidade pela elaboração da legislação de cada estado [19].

Considerando que a saúde e o bem estar humano, assim como o equilíbrio ecológico aquático não deve ser afetado como conseqüência da deterioração da qualidade das águas, e a necessidade de se criar instrumentos para avaliar a evolução da qualidade das águas em relação aos níveis estabelecidos no enquadramento, de forma a facilitar a fixação e controle de 
metas visando atingir gradativamente os objetivos permanentes, o CONAMA edita a Resolução № 20, de 18 de junho de 1986.

A Resolução estabelece em seu Artigo 21 que os efluentes de qualquer fonte poluidora somente poderão ser lançados, diretos ou indiretamente, nos corpos de água, desde que obedeçam a determinadas condições [17].

Em função desta Resolução e dentro do interesse deste trabalho, a TAB. 1 apresenta os valores máximos admissíveis de determinadas substâncias e o $\mathrm{pH}$, estabelecidos pelo CONAMA para efluentes a serem descartados na rede de esgotos.

Tabela 1- Valores máximos admissíveis para descarte de efluentes.

\begin{tabular}{|c|c|}
\hline Substância & Valor limite $\left(\mathbf{m g} \cdot \mathbf{L}^{-1}\right)$ \\
\hline Amônia & 5,0 \\
\hline Fluoretos & 10,0 \\
\hline Urânio total & 0,02 \\
\hline $\mathrm{pH}$ & 5 e 9 \\
\hline
\end{tabular}

\subsection{Normas referentes à efluentes e rejeitos radioativos}

Em relação às Normas relativas aos efluentes radioativos, de acordo com a Constituição Federal, apenas a União tem competência para elaboração das mesmas, o que justifica não existirem Normas Estaduais que tratem desta questão.

Com base na Constituição Federal, em 27 de Agosto de 1962, pela Lei № 4118, foi criada a Comissão Nacional de Energia Nuclear (CNEN), sendo reformulada pela Lei № 6189 de 16 de Dezembro de 1974, atribuindo-se a este órgão, a responsabilidade de promover a utilização da energia nuclear e fiscalizar esta utilização em todo Território Nacional [20 e 21].

Deve-se destacar que de acordo com a Lei № 6189, em seu artigo 2 inciso III, compete à CNEN, baixar normas, regulamentos e especificações relacionadas aos rejeitos radioativos. 
O inciso IV, alíneas a, b e c estabelecem que é competência da CNEN expedir regulamentos e normas de segurança e proteção relativas ao uso de instalações de materiais nucleares, transporte e manuseio.

Com base nesta competência, em 01 de Agosto de 1988 foi aprovada em caráter experimental, a Norma CNEN-NE-3.01 "Diretrizes Básicas de Radioproteção", que revogou a Resolução CNEN-06/73, de 17 de Dezembro de 1973 "Normas Básicas de Proteção Radiológica”, e cujo objetivo principal é estabelecer as Diretrizes Básicas de Radioproteção, abrangendo os princípios, limites, obrigações e controles básicos para a proteção do Homem e de seu meio ambiente contra possíveis efeitos indevidos causados pela radiação ionizante [22].

A Norma CNEN-NE-3.01 se aplica à pessoas físicas e jurídicas envolvidas na produção, uso, posse, armazenamento, processamento, transporte ou deposição de fontes de radiação, define o que é uma Instalação Radioativa e uma Instalação Nuclear e cita que as doses especificadas na Norma não se aplicam à doses resultantes de exposições médicas, naturais ou de emergência.

Com o intuito de estabelecer critérios gerais e requisitos básicos relativos à Gerência de Rejeitos Radioativos de Instalações Radioativas, em 17 de Dezembro de 1985 é aprovada pela Resolução CNEN-19/85, a Norma Experimental CNEN-NE-6.05, "Gerência de Rejeitos Radioativos em Instalações Radioativas" [23].

Na Norma CNEN-NE-6.05 os rejeitos radioativos são classificados de acordo com a sua atividade específica, e ainda, estabelecidos limites explícitos com relação a liberação de efluentes contendo elementos radioativos, para o meio ambiente.

Contudo, deve ser observado que os limites estabelecidos na Norma CNEN-NE-6.05, só se aplicam à Instalações Radioativas, sujeitas ao processo de licenciamento pela CNEN, de acordo com a Norma CNEN-NE-6.02, aprovada pela Resolução CNEN 09/84, em 04 de Dezembro de 1984, "Licenciamento de Instalações Nucleares" [24].

Embora o objetivo principal desta Norma não seja a questão relacionada à liberação de efluentes radioativos para o meio ambiente, é abordado no item 6.4.12, a questão relativa aos sistemas de controle e liberação 
de efluentes radioativos, destacando-se o sub-item "b", que exige das instalações nucleares durante o seu processo de licenciamento, que seja apresentada uma caracterização dos objetivos do projeto e os meios a serem empregados para manter "tão baixo quanto razoavelmente exeqüível, os níveis de materiais radioativos em efluentes liberados em áreas não controladas".

Desta forma, conclui-se que, baseado nas Diretrizes Básicas de Radioproteção, na Norma CNEN-NE-1.04, os limites a serem utilizados para a liberação de efluentes radioativos para o meio ambiente, devem obedecer o princípio “ALARA - As Low As Reasonably Achievable”, ou seja tão baixo quanto razoavelmente exeqüível. 


\section{OBJETIVOS}

\subsection{Objetivos gerais}

O propósito deste trabalho é reutilizar a solução fluoretada gerada no processo de obtenção do amônioperoxidofluoranato-APOFU, ou seja, o filtrado do APOFU, visando a recuperação do fluoreto de amônio $-\mathrm{NH}_{4} \mathrm{~F}$ e do urânio ainda contido, por meio da cristalização do bifluoreto de amônio $-\mathrm{NH}_{4} \mathrm{HF}_{2}$, que será utilizado como matéria-prima na preparação do tetrafluoreto de urânio $\left(\mathrm{UF}_{4}\right)$.

\subsection{Objetivos específicos}

Os objetivos específicos deste trabalho são:

a) Caracterização química do efluente fluoretado (filtrado VIII);

b) Tratamento do efluente do APOFU, por meio da cristalização do composto $\mathrm{NH}_{4} \mathrm{~F}$;

c) Estudar a fluoração dos compostos de urânio: $\mathrm{U}_{3} \mathrm{O}_{8}$ e $\mathrm{UO}_{2}$;

d) Estudar a decomposição do $\mathrm{NH}_{4} \mathrm{UF}_{5}$;

e) Caracterização do produto obtido $-U_{4}$. 


\section{FUNDAMENTAÇÃO TEÓRICA}

\subsection{Aspectos gerais.}

Dentre os objetivos do IPEN-CNEN/SP [25] na sua atribuição básica de realizar pesquisas científicas e desenvolvimentos tecnológicos na área nuclear, procurando aplicar os conhecimentos adquiridos nesta área em benefício da sociedade brasileira, destacam-se as aplicações da radiação e de radioisótopos na medicina, indústria, agropecuária e meio ambiente. Um esforço polarizado tem sido orientado nesta direção desde praticamente a fundação da Instituição.

No IPEN-CNEN/SP são produzidos, processados e distribuídos radioisótopos, radiofármacos, substâncias marcadas e outros insumos usados em medicina nuclear que hoje atingem cerca de 360 clínicas, hospitais e universidades em todo Brasil, permitindo o atendimento de aproximadamente 1.000 .000 pacientes por ano, número que vem crescendo a taxa superior a $20 \%$ ao ano.

Em 1959, o IPEN-CNEN/SP iniciou suas atividades de Radiofarmácia, produzindo o iodo-131, destinado ao diagnóstico e terapia da tireóide. Na década de sessenta essas atividades se consolidaram e se ampliaram e diversos radiofármacos foram produzidos, dentre eles o fósforo-32 para tratamento de policetemia vera, o ouro coloidal-198 para estudo da função renal e tratamento de tumores intracavitários, o cromo-51 para marcação de proteínas séricas e o potássio-42 e o sódio-24 para medidas de intercâmbio desses dois elementos no organismo humano. Nessa mesma época, iniciou-se a produção de diversas substâncias marcadas com iodo-131 e cromo-51, utilizadas no diagnóstico de diferentes funções orgânicas. Em 1981, o IPEN-CNEN/SP iniciou a produção de geradores de tecnécio-99m e conjuntos reativos para serem marcados com esse isótopo. Hoje, esse produto é o mais importante radiofármaco para a medicina nuclear produzido pela Instituição, sendo responsável por cerca de $80 \%$ de todos os diagnósticos da medicina nuclear realizados no país. 
Em 1987, foi iniciada a produção do gálio-67, o primeiro radiofármaco produzido no IPEN-CNEN/SP utilizando acelerador ciclotron, usado para diagnósticos de tumores em tecidos moles e em processos inflamatórios. Em 1994, iniciou-se a produção de outro radiofármaco de ciclotron, o iodo-123, para diagnóstico da função tireoideana. Em setembro de 1995, com a alteração no esquema operacional do reator nuclear de pesquisas do IPEN-CNEN/SP, que passou a operar 60 horas contínuas por semana, iniciou-se a produção e a distribuição para todo o país do primeiro radioterápico de segunda geração, o samário-153 ETDMP, usado para alívio das metástases ósseas.

Considerando-se a importância social e estratégica da produção de radiofármacos no país e o contínuo crescimento de dispêndios na importação dos radioisótopos necessários para atender a essa produção, o Governo Federal, através da Secretaria de Assuntos Estratégicos e da Comissão Nacional de Energia Nuclear, decidiu de maneira incisiva investir nessa área, principalmente no IPEN-CNEN/SP. Como conseqüência, em 1995 um importante e significativo aporte de recurso financeiro permitiram iniciar reformas substanciais nos laboratórios e na instalação de produção de radiofármacos, assim como no reator nuclear de pesquisas IEA-R1, do IPEN-CNEN/SP.

O processo mais conhecido para obtenção do radioisótopo molibdênio99, usado para a produção dos geradores de tecnécio-99m, utiliza a irradiação de alvos de urânio altamente enriquecido no isótopo urânio-235 em reatores nucleares. O molibdênio-99 produzido na irradiação pela fissão do urânio-235, é posteriormente separado através de processos químicos complexos. A decisão de se aumentar a potência do reator IEA-R1 de 2 para $5 \mathrm{MW}$ e de se alterar o ritmo de operação para 100 horas contínuas por semana, criou condições para produção de importante impacto social, a do molibdênio-99, matéria-prima para a obtenção do tecnécio-99m. Esses trabalhos vêm sendo desenvolvidos com a colaboração da Agência Internacional de Energia Atômica e do Power Institute of China.

Os aumentos da potência do reator IEA-R1 de 2 para $5 \mathrm{MW}$, bem como de seu regime operacional necessário à viabilização deste programa, implicaram na necessidade de ampliação da atual capacidade de produção de elementos combustíveis decorrente do aumento do consumo do reator sob estas novas 
condições operacionais. Durante muitos anos, o IPEN-CNEN/SP trabalhou no desenvolvimento do processo de fabricação de elementos combustíveis usados internacionalmente em reatores de pesquisas, visando a nacionalização da sua produção para utilização no seu reator IEA-R1. Desde sua inauguração e durante quase três décadas, ao longo de uma época de incertezas quanto ao mercado de materiais nucleares, o reator IEA-R1 dependeu totalmente da importação dos elementos combustíveis necessários para sua operação, fornecidos durante este período pela GENERAL ATOMICS americana (93\% em $\left.{ }^{235} \mathrm{U}\right)$ e NUKEM (20\% em ${ }^{235} U$ ) alemã.

Este contexto determinou a necessidade de implantação de uma nova unidade de produção no Centro do Combustível Nuclear, planejada para utilizar tanto os pós de $\mathrm{U}_{3} \mathrm{O}_{8}$ como os de $\mathrm{U}_{3} \mathrm{Si}_{2}$ [26] na fabricação dos elementos combustíveis mencionados anteriormente permitindo flexibilidade na produção de combustíveis à base de $\mathrm{U}_{3} \mathrm{O}_{8}$ e $\mathrm{U}_{3} \mathrm{Si}_{2}$.

Placas combustíveis à base de dispersões de silicetos de urânio em alumínio são capazes de incorporar quantidades de urânio bastante superiores às obtidas com a utilização de $\mathrm{U}_{3} \mathrm{O}_{8}$. A utilização do $\mathrm{U}_{3} \mathrm{Si}_{2}$ possibilita a incorporação de concentrações de urânio de aproximadamente $5 \mathrm{~g} \mathrm{U} / \mathrm{cm}^{3}$ contra a concentração máxima de $3,2 \mathrm{~g} \mathrm{U} / \mathrm{cm}^{3}$ relativa ao emprego do $\mathrm{U}_{3} \mathrm{O}_{8}$, como decorrência do limite tecnológico de fabricação do combustível contendo $45 \%$ em volume da fase físsil dispersa [27].

A produção de compostos metálicos de urânio, necessariamente necessita partir de urânio metálico, que foi pela primeira vez produzido em 1841 a partir de $\mathrm{UF}_{4}$ [28]. Atualmente, toda a produção mundial de urânio metálico consiste na redução de $U_{4}$ pelo magnésio ou cálcio [29].

No Centro de Combustível Nuclear - CCN do IPEN/CNEN - SP, uma das rotas nos processos de reconversão de $U_{6}$, consiste na preparação de $U_{4}$ via aquosa a partir da solução de fluoreto de uranilo, fazendo uso de cloreto de estanho II como redutor e precipitação pela adição de ácido fluorídrico.

Outra possibilidade para a obtenção de $U_{4}$, via seca, disponível no CCN, é a rota da fluoretação a partir da redução do tricarbonato de uranilo TCAU, que permite flexibilizar também a produção de $\mathrm{U}_{3} \mathrm{O}_{8}$. $\mathrm{O}$ processo basicamente consiste na produção de TCAU a partir do $\mathrm{UF}_{6}$, que poderá ser 
reduzido à $\mathrm{UO}_{2}$ ou oxidado à $\mathrm{U}_{3} \mathrm{O}_{8}$, num forno rotativo com atmosferas redutoras ou oxidantes, respectivamente. $\mathrm{O}$ pó de $\mathrm{UO}_{2}$ deverá ser fluoretado num forno estático com atmosfera de HF.

Em qualquer uma das rotas, após a redução do $\mathrm{UF}_{4}$ à $\mathrm{U}^{0}$, este último sofre adição do silício metálico e, através de fusão em forno de indução, é obtido o intermetálico $\mathrm{U}_{3} \mathrm{Si}_{2}$.

\subsection{Efluentes fluoretados gerados na etapa de Reconversão de Urânio}

No Centro de Combustível Nuclear - CCN, do Instituto de Pesquisas Energéticas e Nucleares, IPEN-CNEN/SP, os processos de reconversão do UF 6 adotados para a produção de elementos combustíveis consistem na obtenção de $\mathrm{U}_{3} \mathrm{O}_{8}$ e/ou $\mathrm{U}_{3} \mathrm{Si}_{2}$ através de rotas de preparação de compostos intermediários dentre eles o tricarbonato de amônio -TCAU, diuranato de amônio - DUA e o tetrafluoreto de urânio - $\mathrm{UF}_{4}$. Em todas as rotas adotadas geram-se efluentes líquidos conforme diagrama de blocos apresentado na FIG. 3. 


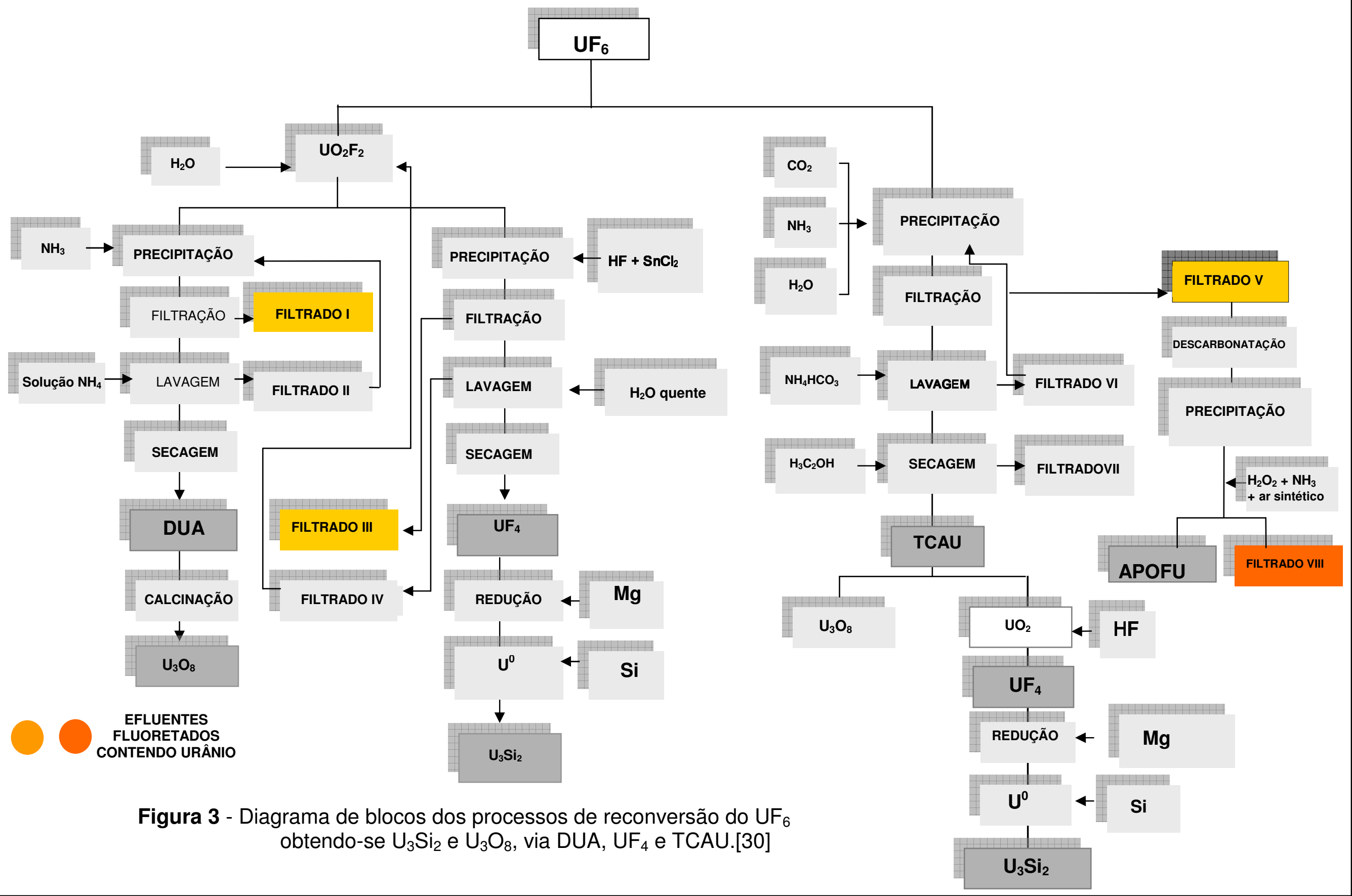




\subsubsection{Obtenção de DUA}

a. Filtrado I: resultante da precipitação de DUA com as características apresentadas na TAB. 2.

Tabela 2 - Composição média do filtrado do DUA

\begin{tabular}{|c|c|}
\hline Íon & Concentração média \\
\hline $\mathrm{U}^{+6}$ & $8 \mathrm{mg} \cdot \mathrm{L}^{-1}$ \\
\hline $\mathrm{NH}_{4}$ & $8,82 \mathrm{~g} \cdot \mathrm{L}^{-1}$ \\
\hline $\mathrm{F}^{-}$ & $69 \mu \mathrm{g} \cdot \mathrm{mL}^{-1}$ \\
\hline $\mathrm{pH}$ & 9,2 \\
\hline
\end{tabular}

Este efluente é tratado por meio de troca iônica e o urânio recuperado como carbonato de uranilo [31].

b. Filtrado II: resultante da etapa de lavagem do DUA e retorna ao processo de hidrólise do $U_{6}$.

\subsubsection{Obtenção de UF $_{4}$}

a. Filtrado III: resultante do processo de precipitação de urânio com ácido fluorídrico e cloreto de estanho II, tendo as características apresentadas na TAB. 3.

Tabela 3 - Composição média do filtrado do $U_{4}$

\begin{tabular}{|c|c|}
\hline Íon & Concentração média \\
\hline $\mathrm{U}^{+6}$ & $662 \mu \mathrm{g} \cdot \mathrm{mL}^{-1}$ \\
\hline $\mathrm{F}^{-}$ & $47 \mu \mathrm{g} \cdot \mathrm{mL}^{-1}$ \\
\hline $\mathrm{Sn}$ & $20 \mathrm{~g} \cdot \mathrm{L}^{-1}$ \\
\hline $\mathrm{Cl}^{-}$ & $12 \mu \mathrm{g} \cdot \mathrm{mL}^{-1}$ \\
\hline $\mathrm{pH}$ & 2,43 \\
\hline
\end{tabular}

O tratamento deste efluente está em fase de desenvolvimento no Centro de Combustível Nuclear - CCN do IPEN-CNEN/SP. 
b. Filtrado IV: resultante da etapa de lavagem do $\mathrm{UF}_{4}$ com $\mathrm{H}_{2} \mathrm{O}$. Este efluente retorna ao processo na etapa de hidrólise do $\mathrm{UF}_{6}$.

\subsubsection{Obtenção de TCAU [32].}

O cilindro de $U_{6}$ é introduzido em uma autoclave e aquecido com vapor saturado até uma temperatura de $95^{\circ} \mathrm{C}$.

A hidrólise do $U_{6}$ e a precipitação do TCAU, ocorrem em um reator químico despressurizado. No reator adiciona-se $\mathrm{NH}_{3}, \mathrm{CO}_{2}$ e $\mathrm{H}_{2} \mathrm{O}$, formando uma solução de bicarbonato de amônio. Após atingir a concentração desejada adiciona-se simultaneamente $0 \mathrm{UF}_{6}$ pelo mesmo bico injetor onde flui o $\mathrm{CO}_{2}$. $\mathrm{A}$ diluição do $\mathrm{UF}_{6}$ é feita com $\mathrm{CO}_{2}$ para melhorar a sua eficiência de absorção e evitar a obstrução do bico injetor, visto que o contato do $U_{6}$ com a solução aquosa recirculante provoca imediata precipitação de um composto de urânio que pode obstruir a sua entrada. A vazão do $U_{6}$ deve ser rigorosamente controlada, pois esta, juntamente com a temperatura de precipitação vão determinar a granulometria do TCAU.

Após o término da alimentação do $U_{6}$, continua-se por mais alguns minutos a alimentação de $\mathrm{CO}_{2}$ e $\mathrm{NH}_{3}$ para diminuir a solubilidade do precipitado e garantir que todo $0 \mathrm{UF}_{6}$ tenha sido arrastado das tubulações e absorvido na solução.

A dosagem dos reagentes é realizada de maneira que $0 \mathrm{pH}$ da suspensão fique entre 8,5 e 9,0, que é o pH de precipitação do TCAU.

A suspensão após resfriada é transferida para um filtro horizontal rotativo a vácuo. O filtro é composto de um disco horizontal e de um raspador. Inicia-se, portanto, a primeira filtração.

O filtrado desta primeira filtração (filtrado V) é enviado para um vaso de decantação. Antes de ser realizada a primeira filtração da batelada seguinte, retira-se o sobrenadante deste vaso, que é enviado para a Unidade de Tratamento dos filtrados, para a recuperação do urânio residual.

Terminada a primeira filtração, a próxima etapa é a lavagem da torta de TCAU com a solução de $\mathrm{NH}_{4} \mathrm{HCO}_{3} 1,0 \mathrm{M}$, cuja finalidade é retirar o fluoreto. Realiza-se então a segunda filtração cujo filtrado, é bombeado para o reator, 
recirculado por alguns minutos e enviado novamente para o filtro. Essa operação é feita para a limpeza do reator e das linhas.

Inicia-se então a terceira filtração onde o filtrado gerado (filtrado VI) é utilizado na precipitação do TCAU da batelada seguinte.

Após a filtração, é realizada uma etapa de lavagem do TCAU com etanol anidro para baixar o teor de umidade. O filtrado desta quarta filtração (filtrado VII) é coletado em um vaso de decantação.

Portanto, no processo de obtenção de TCAU geram-se três efluentes:

a. Filtrado V: resultante da primeira filtração do TCAU, com as características apresentadas na TAB. 4.

Tabela 4 - Composição média do filtrado do TCAU

\begin{tabular}{|c|c|}
\hline Íon & Concentração média \\
\hline $\mathrm{U}^{+6}$ & $300 \mathrm{mg} \cdot \mathrm{L}^{-1}$ \\
\hline $\mathrm{NH}^{+}{ }^{+}$ & $110 \mathrm{~g} \cdot \mathrm{L}^{-1}$ \\
\hline $\mathrm{F}^{-}$ & $100 \mathrm{~g} \cdot \mathrm{L}^{-1}$ \\
\hline $\mathrm{CO}_{3}{ }^{-}+\mathrm{HCO}_{3}{ }^{-}$ & $80 \mathrm{~g} \cdot \mathrm{L}^{-1}$ \\
\hline \hline densidade & $1,080 \mathrm{~g} \cdot \mathrm{cm}^{-3}$ \\
\hline $\mathrm{pH}$ & 9,0 \\
\hline
\end{tabular}

b. Filtrado $\mathrm{VI}$, proveniente da lavagem do TCAU, mas retorna ao processo na próxima batelada para o reator de hidrólise do $\mathrm{UF}_{6}$;

c. Filtrado VII, que consiste basicamente de álcool etílico $\left(\mathrm{H}_{5} \mathrm{C}_{2} \mathrm{OH}\right)$ utilizado na lavagem do TCAU com finalidade de reduzir o teor de umidade no produto.

\subsubsection{Obtenção do amonioperoxidofluoranato - APOFU}

O Filtrado $V$ é tratado através da reação do urânio com peróxido de hidrogênio obtendo-se o APOFU [30].

O filtrado proveniente da conversão de $\mathrm{UF}_{6}$ a TCAU (20 litros) é encaminhado para um reator de descarbonatação dotado de um borbulhador de ar e um agitador mecânico. Inicialmente, este filtrado é aquecido a $95{ }^{\circ} \mathrm{C}$ e permanece por um tempo de 15 a 20 minutos, para ocorrer a liberação dos íons 
carbonato, na forma de $\mathrm{CO}_{2}$. Após a descarbonatação o volume será aproximadamente 16 litros e o $\mathrm{pH}$ será 7.

Após o término da descarbonatação a solução é resfriada, passando-se água pela camisa do reator, até que atinja $50-60^{\circ} \mathrm{C}$. A solução estará isenta ou pobre de íons carbonato.

Inicia-se o borbulhamento de ar e $\mathrm{NH}_{3}$ até atingir o $\mathrm{pH} 8,5$. A temperatura é mantida constante a $60{ }^{\circ} \mathrm{C}$, por meio de aquecimento elétrico. Adiciona-se lentamente $\mathrm{H}_{2} \mathrm{O}_{2} \quad 30 \%$ com agitação mecânica e borbulhamento simultâneo de ar e $\mathrm{NH}_{3}$, para controlar o pH de precipitação.

Uma solução amarelo-avermelhada é obtida, e agitada vigorosamente até aparecer a primeira turbidez (30 $\mathrm{min})$.

Após a precipitação do urânio, interrompe-se o fornecimento de calor e deixa-se a solução em repouso por um período de 2,5 horas, e em seguida $90 \%$ do sobrenadante é retirado (filtrado VIII).

A polpa de precipitação do APOFU é enviada para a centrífuga com o objetivo de separar o APOFU do filtrado. Após todo o filtrado ter sido liberado na centrífuga, lava-se o APOFU com água.

A torta resultante da centrifugação terá uma concentração de $20 \%$ de umidade e posteriormente será enviada para um processo de calcinação, visando a obtenção do $\mathrm{U}_{3} \mathrm{O}_{8}$.

O processo irá gerar 15,7 g de pó na forma de APOFU e 16 litros de solução de $\mathrm{NH}_{4} \mathrm{~F}$.

Este processo químico gera somente um efluente cujas características estão apresentadas na TAB. 5.

Tabela 5 - Composição média do filtrado do APOFU

\begin{tabular}{|c|c|}
\hline Íon & Concentração média \\
\hline $\mathrm{U}^{+6}$ & $6 \mathrm{mg} \cdot \mathrm{L}^{-1}$ \\
\hline $\mathrm{NH}^{+}{ }_{4}$ & $100 \mathrm{~g} \cdot \mathrm{L}^{-1}$ \\
\hline $\mathrm{F}^{-}$ & $120 \mathrm{~g} \cdot \mathrm{L}^{-1}$ \\
\hline $\mathrm{CO}_{3}{ }^{-}+\mathrm{HCO}_{3}{ }^{-}$ & $4 \mathrm{~g} \cdot \mathrm{L}^{-1}$ \\
\hline densidade & $1,084 \mathrm{~g} \cdot \mathrm{cm}^{-3}$ \\
\hline $\mathrm{pH}$ & 8,5 \\
\hline
\end{tabular}


O teor de urânio presente nesta solução não nos permite liberar para o meio ambiente existindo ainda a necessidade de tratamento para o seu descarte. Este filtrado será o foco de estudo deste trabalho.

\subsection{Tetrafluoreto de urânio - UF $_{4}$}

\subsubsection{Importância e especificações.}

$\mathrm{O} \mathrm{UF}_{4}$ apresenta um papel relevante na tecnologia dos combustíveis nucleares. É um produto intermediário de grande importância, a partir do qual são produzidos urânio metálico e hexafluoreto de urânio.

Em princípio, diversos outros compostos podem também ser usados para a produção do metal e do hexafluoreto; contudo, o uso do UF 4 é prescrito por considerações tecnológica e econômica. É, consideravelmente mais fácil obter urânio metálico do $\mathrm{UF}_{4}$ do que dos óxidos, isto devido à reatividade de uma mistura de $\mathrm{UF}_{4}$ com o agente redutor e o grande efeito térmico, que facilita a produção de um ligote monolítico do metal.

De acordo com o processo a que ele é submetido, o UF 4 deve apresentar certas especificações com respeito a sua pureza, ao teor de óxidos de urânio e de fluoreto de uranilo $\left(\mathrm{UO}_{2} \mathrm{~F}_{2}\right)$, e também sua densidade aparente e sua composição granulométrica.

A maior exigência técnica é observada para o tetrafluoreto destinado à preparação de urânio metálico. Deve conter não menos que 96\% de tetrafluoreto, ser praticamente livre de impurezas, ser anidro e ter densidade aparente suficientemente alta. No caso do teor de óxidos ser alto, verificam-se grandes perdas do metal com a escória. Como durante a fundição é desenvolvida uma grande quantidade de calor, o tetrafluoreto não deve apresentar componentes voláteis, tais como água e amônia. Durante a fundição, o metal é ligeiramente contaminado com impurezas do agente redutor e do equipamento; por esta razão o $\mathrm{UF}_{4}$ deve ser suficientemente puro para permitir um certo grau de contaminação durante esse processo. Deve, também ser suficientemente denso. A carga para fundição consiste do pó de tetrafluoreto e aparas de cálcio ou magnésio; quanto mais alta a densidade solta do $\mathrm{UF}_{4}$, tanto maior será a densidade solta da carga, e tanto maior a quantidade de calor envolvida por unidade de volume da fornalha 
[33]. É recomendável que a densidade solta do $\mathrm{UF}_{4}$ seja maior que $1 \mathrm{~g} \cdot \mathrm{cm}^{-3}$, que o habilitem na redução por magnésiotermia [34].

Objetivando a boa qualidade do urânio metálico a ser produzido, o $\mathrm{UF}_{4}$ deve apresentar características específicas [35], tais como apresentadas nas TAB. 6 e 7 :

Tabela 6 - Especificações dos limites das principais impurezas em UF 4

\begin{tabular}{|c|c|}
\hline Elemento & $\boldsymbol{\mu g}^{-\mathbf{g}^{-1}}$ \\
\hline $\mathrm{Al}$ & 70 \\
\hline $\mathrm{B}$ & 0,2 \\
\hline $\mathrm{Cd}$ & 0,1 \\
\hline $\mathrm{C}$ & 150 \\
\hline $\mathrm{Co}$ & 5 \\
\hline $\mathrm{Cr}$ & 25 \\
\hline $\mathrm{Cu}$ & 40 \\
\hline $\mathrm{Fe}$ & 75 \\
\hline $\mathrm{Mn}$ & 15 \\
\hline $\mathrm{Ni}$ & 40 \\
\hline $\mathrm{Si}$ & 30 \\
\hline
\end{tabular}

Quando o processo de redução for realizado sob maiores pressões e menores temperaturas, tolera-se até $4 \%$ de $\mathrm{UO}_{2}+\mathrm{UO}_{2} \mathrm{~F}_{2}$, que seriam reduzidos.

Tabela 7 - Distribuição do tamanho das partículas recomendada para o UF 4 .

\begin{tabular}{|c|c|}
\hline Malha em mesh & \% massa retida \\
\hline$<20$ & 0,73 \\
\hline $20-40$ & 1,81 \\
\hline $40-60$ & 2,18 \\
\hline $60-80$ & 3,75 \\
\hline $80-100$ & 11,37 \\
\hline $100-325$ & 73,52 \\
\hline$>325$ & 6,64 \\
\hline
\end{tabular}


A obtenção de tetrafluoreto de urânio pode ser realizada por diversos processos que são divididos em dois grupos, ou seja, via seca e via aquosa [36, $37,38,39,40]$.

Os primeiros trabalhos de obtenção de $U_{4}$ foram realizados por via aquosa $[40,41]$ no final do século XIX e tiveram preponderância, sob o ponto de vista industrial, até meados do século $X X$.

Com o desenvolvimento dos processos por via seca, aqueles por via aquosa foram abandonados por apresentarem dificuldades de filtração, lavagem e secagem, apesar de apresentarem simplicidade e segurança.

\subsubsection{Processos de obtenção de $\mathrm{UF}_{4}$ por via úmida}

\subsubsection{Preparação de $\mathrm{UF}_{4}$ a partir de sais de $\mathrm{U}^{+6}$}

Os métodos de preparação de $\mathrm{UF}_{4}$ por via aquosa foram desenvolvidos em sua maioria pelos ingleses e suas modificações foram baseadas no trabalho desenvolvido por Bolton em 1866 [42,43].

Essencialmente os processos consistem na redução do urânio, contido em soluções de fluoreto de uranilo, cloreto de uranilo ou sulfato de uranilo para o estado tetravalente e a precipitação do tetrafluoreto de urânio pela adição de ácido fluorídrico. Vários compostos de urânio têm sido empregados como materiais de partida e vários agentes redutores tem sido utilizado.

Uma visão geral do processo pode ser obtida das reações de fluoreto de uranilo com cloreto de estanho II e com hiposulfito de sódio.

$$
\begin{aligned}
& \mathrm{UO}_{2} \mathrm{~F}_{2}+\mathrm{SnCl}_{2}+4 \mathrm{HF} \leftrightarrow \mathrm{UF}_{4}+\mathrm{SnCl}_{2} \mathrm{~F}_{2}+2 \mathrm{H}_{2} \mathrm{O} \ldots \ldots \ldots \ldots \ldots . . . . . . . .(01) \\
& \mathrm{UO}_{2} \mathrm{~F}_{2}+\mathrm{Na}_{2} \mathrm{~S}_{2} \mathrm{O}_{4}+2 \mathrm{HF} \leftrightarrow \mathrm{UF}_{4}+\mathrm{Na}_{2} \mathrm{SO}_{3}+\mathrm{SO}_{2}+\mathrm{H}_{2} \mathrm{O} \ldots \ldots \ldots(02) \\
& \text { Uma alternativa para este processo é a substituição dos agentes }
\end{aligned}
$$
redutores pela redução eletrolítica que evita a possível contaminação com o agente redutor. Este processo tem sido adotado em países como Estados Unidos, Espanha, Austrália, Japão, Canadá, Inglaterra, África do Sul e Índia [44,45,46, $47,48,49,50]$. 


\subsubsection{Preparação de $\mathrm{UF}_{4}$ a partir de $\mathrm{UO}_{2}$}

O UF 4 obtido da reação com $\circ U_{2}$ com ácido fluorídrico é de fácil preparação. A reação pode ser resumida como segue:

$$
\mathrm{UO}_{2}(\mathrm{~s})+4 \mathrm{HF}(\mathrm{aq}) \leftrightarrow \mathrm{UF}_{4}(\mathrm{~s})+2 \mathrm{H}_{2} \mathrm{O}
$$

Este processo tem algumas vantagens em relação aos outros visto que como a reação ocorre a baixas temperaturas o reator pode ser construído em polietileno, polipropileno ou aço carbono revestido com plástico enquanto outros processos exigem equipamentos construídos com metais (monel, inconel, níquel) o que encarece o custo de uma planta.

\subsubsection{Processos de obtenção de $\mathrm{UF}_{4}$ por via seca}

\subsubsection{Preparação de $\mathrm{UF}_{4}$ por fluoretação do $\mathrm{UO}_{2}$}

A obtenção de $\mathrm{UF}_{4}$ por esse processo foi adotada no Canadá, França, Antiga Checoslováquia, África do Sul, Estados Unidos, Portugal, Brasil, Alemanha e Suécia [33, 39,51].

A seqüência de operações consiste na redução de $\mathrm{UO}_{3}$ por hidrogênio, seguida do tratamento do $\mathrm{UO}_{2}$ resultante com $\mathrm{HF}$ anidro, à pressão atmosférica.

$$
\begin{aligned}
& \mathrm{UO}_{3}(\mathrm{~s})+\mathrm{H}_{2}(\mathrm{~g}) \leftrightarrow \mathrm{UO}_{2}(\mathrm{~s})+\mathrm{H}_{2} \mathrm{O}(\mathrm{v}) \ldots . . \\
& \mathrm{UO}_{2}(\mathrm{~s})+4 \mathrm{HF}(\mathrm{g}) \leftrightarrow \mathrm{UF}_{4}(\mathrm{~s})+2 \mathrm{H}_{2} \mathrm{O}(\mathrm{v})
\end{aligned}
$$

A redução do $\mathrm{UO}_{3}$ é realizada em temperaturas de $500-700^{\circ} \mathrm{C}$. Outra alternativa é a redução do octóxido de urânio, recomendada quando se tem problemas de armazenamento de $\mathrm{UO}_{3}$, por ser extremamente higroscópio.

$$
\mathrm{U}_{3} \mathrm{O}_{8}(\mathrm{~s})+2 \mathrm{H}_{2}(\mathrm{~g}) \leftrightarrow 3 \mathrm{UO}_{2}(\mathrm{~s})+2 \mathrm{H}_{2} \mathrm{O}(\mathrm{v})
$$

Neste tipo de processo utilizam-se comumente reatores tipo leito móvel ou leito fluidizado.

\subsubsection{Preparação de $\mathrm{UF}_{4}$ por reação de $\mathrm{UO}_{3} \operatorname{com} \mathrm{NH}_{3}$ e HF gasoso}

O processo consta de apenas uma etapa para a obtenção do UF $_{4}$ consistindo da passagem da mistura $\mathrm{NH}_{3}$ e $\mathrm{HF}$ pelo $\mathrm{UO}_{3}$ a $500-700^{\circ} \mathrm{C}$. A reação é rápida e produz $\mathrm{UF}_{4}$ de alta pureza: 
$3 \mathrm{UO}_{3}+2 \mathrm{NH}_{3}+12 \mathrm{HF} \leftrightarrow 3 \mathrm{UF}_{4}+9 \mathrm{H}_{2} \mathrm{O}+\mathrm{N}_{2}$

Preparação de $U_{4}$ pela reação de óxidos de urânio com hidrocarbonetos fluorados (freon). A reação que ocorre é a seguinte:

$$
2 \mathrm{CF}_{2} \mathrm{Cl}_{2}+\mathrm{UO}_{3} \leftrightarrow \mathrm{UF}_{4}+\mathrm{CO}_{2}+\mathrm{COCl}_{2}+\mathrm{Cl}_{2}
$$

A literatura mostra resultados das reações de diferentes freons com os óxidos de urânio $\cup_{2}, \mathrm{U}_{3} \mathrm{O}_{8}$ e $\cup_{3}[33,38,40]$.

Os reatores utilizados neste processo não podem ser construídos em níquel, cobre, platina e aço inoxidável por sofrerem ataque químico dos reagentes, além de promoverem pirólise com a disposição de carbono.

Os reatores devem ser construídos de grafita ou fluoreto de cálcio ocasionando conseqüentemente uma contaminação no UF 4 obtido. As vantagens desde método são a simplicidade de equipamentos e a possibilidade de aplicação da reação para todos os óxidos de urânio.

\subsubsection{Preparação de $\mathrm{UF}_{4}$ a partir de urânio metálico ou de hidreto de urânio metálico $\left(\mathrm{UH}_{3}\right)$ por fluoretação em altas temperaturas}

O urânio metálico pode ser rapidamente convertido em tetrafluoreto de urânio por meio das reações abaixo indicadas:

$$
\begin{aligned}
& \mathrm{U}+3 / 2 \mathrm{H}_{2} \stackrel{250^{\circ} \mathrm{C}}{\longleftrightarrow} \mathrm{UH}_{3} \ldots \ldots \ldots \ldots . . . . . . \\
& \mathrm{UH}_{3}+4 \mathrm{HF} \stackrel{200^{\circ} \mathrm{C}}{\longleftrightarrow} \mathrm{UF}_{4}+7 / 2 \mathrm{H}_{2} .
\end{aligned}
$$

Industrialmente o urânio metálico é fabricado a partir do $U_{4}$. Não existindo vantagem em obter primeiro o urânio elementar e transformá-lo em $\mathrm{UH}_{3}$, para depois chegar ao $\mathrm{UF}_{4}$.

\subsubsection{Processos de obtenção de $\mathrm{UF}_{4}$ por via seca com bifluoreto de amônio $\left(\mathrm{NH}_{4} \mathrm{HF}_{2}\right)$.}

\subsubsection{Processo da Mallincrodt}

Em dezembro de 1942, na instalação para produção de $U_{4}$ da Mallincrodt Chemical Works[52], informações vindas da Du Point Company 
indicavam que $\mathrm{o} \mathrm{UO}_{2}$ tratado com $\mathrm{HF}$ a uma temperatura de aproximadamente $600^{\circ} \mathrm{C}$, produzia $\mathrm{UF}_{4}$ com eficiência.

Devido à escassez de informações referentes a esta reação, foi iniciado um trabalho em uma instalação em escala piloto, para determinar as condições necessárias para produzir eficientemente, em larga escala, $\mathrm{UF}_{4}$ de alta qualidade. O objetivo então foi obter informações empíricas nas quais a construção e operação desta instalação poderiam ser baseadas.

Antes da adaptação final do grau de alcalinização do HF como reagente para conversão do $U_{2}$ em $U_{4}$, algumas experiências foram conduzidas para determinar a possibilidade do uso do $\mathrm{NH}_{4} \mathrm{HF}_{2}$, devido às vantagens óbvias de manuseio e relativa segurança.

Misturas de $\mathrm{UO}_{2}$ com $\mathrm{NH}_{4} \mathrm{HF}_{2}$ em excesso foram colocadas em uma mufla elétrica e mantidas a uma temperatura razoavelmente constante. Em alguns casos uma pequena quantidade de água foi adicionada à mistura. $\mathrm{O}$ resultado está resumido na TAB. 8:

Tabela 8 - Resultados obtidos na conversão do $\mathrm{UO}_{2}$ em $\mathrm{UF}_{4}$ pela reação com $\mathrm{NH}_{4} \mathrm{HF}_{2}$, na instalação da Mallincrodt Chemical Works.

\begin{tabular}{|c|c|c|c|c|c|c|}
\hline $\begin{array}{c}\text { Experiência } \\
\mathbf{N}{ }^{\circ}\end{array}$ & $\begin{array}{c}\text { Excesso de } \\
\mathbf{N H}_{4} \mathbf{H F}_{2} \text { em } \\
\text { Mol (\%) }\end{array}$ & $\begin{array}{c}\text { Vapor de } \\
\text { água/grama } \\
\text { de mistura }\end{array}$ & $\begin{array}{c}\text { Temperatura } \\
{ }^{\circ} \mathbf{C}\end{array}$ & $\begin{array}{c}\% \\
\text { IOA (a) }\end{array}$ & $\begin{array}{c}\% \\
\mathbf{N H}_{3}\end{array}$ & $\begin{array}{c}\text { Tempo } \\
\text { em Horas }\end{array}$ \\
\hline $135 \mathrm{~A}$ & 50 & 0,1 & 150 & 14,1 & - & 3 \\
\hline $135 \mathrm{~B}$ & 50 & 0,05 & 150 & 11,6 & - & 3 \\
\hline 137 & 50 & 0,8 & 150 & 9,9 & $8,01-8,02$ & 3 \\
\hline 140 & 50 & 0 & $150-300$ & 6,0 & - & 6,5 \\
\hline 129 & 5 & 0 & 500 & 13,7 & - & 5 \\
\hline 132 & 10 & 0 & 500 & 17,8 & - & 5,3 \\
\hline 138 & 50 & 0 & 500 & 6,2 & $0,97-0,22$ & 4 \\
\hline 139 (b) & 50 & 0 & 500 & 0,9 & $0,37-0,46$ & 7 \\
\hline 141 (b) & 75 & 0 & 500 & 1,3 & - & 12 \\
\hline
\end{tabular}

(a) O termo IOA refere-se ao material insolúvel em solução aquosa de oxalato de amônia. Visto que o $\mathrm{UF}_{4}$ e $\mathrm{UO}_{2} \mathrm{~F}_{2}$ são solúveis em solução aquosa de oxalato de amônio, a porção insolúvel representa óxidos não convertidos.

(b) O material nas experiências 139 e 141 foi tratado anteriormente com vapor de HF por uma hora, antes de ser removido do forno mufla. 
Conforme se nota na TAB. 8, a conversão do $U_{2}$ pela reação com $\mathrm{NH}_{4} \mathrm{HF}_{2}$ à $150{ }^{\circ} \mathrm{C}$ é extremamente incompleta, salvo se uma considerável quantidade de mistura está presente. A reação a $500^{\circ} \mathrm{C}$ apresentou resultados mais animadores, porém o uso acima de $80 \%$ em excesso de $\mathrm{NH}_{4} \mathrm{HF}_{2}$ não foi justificado.

Visto que pareceu evidente que o HF poderia ser utilizado para conversão dos traços finais de $\mathrm{UO}_{2}$, a vantagem do $\mathrm{NH}_{4} \mathrm{HF}_{2}$ foi anulada, sendo que o mesmo foi descartado como possível agente de fluoração.

\subsubsection{Processo Belga}

No processo Belga[28], a fluoração do $\mathrm{UO}_{2}$ é efetuada com $\mathrm{NH}_{4} \mathrm{HF}_{2}$, um sólido branco que não se dissolve, possui baixa pressão de vapor e pode ser manuseado livremente visto que não é tóxico.

Em uma etapa inicial, o $\mathrm{UO}_{2}$ é misturado com o bifluoreto, $20 \%$ acima da quantidade exigida pelo cálculo estequiométrico. O cristal de bifluoreto é facilmente moído, e a mistura de $\mathrm{UO}_{2}+\mathrm{NH}_{4} \mathrm{HF}_{2}$ é feita em um container de madeira para evitar contaminação.

A conversão do bifluoreto ocorrerá em temperatura ambiente aproximadamente após 24 horas, embora sob tais condições a água formada na redução pode estar retida. A eliminação da água e $\mathrm{NH}_{3}$ é facilitada pela reação do $\mathrm{UO}_{2}$ e $\mathrm{NH}_{4} \mathrm{HF}_{2}$ a $150^{\circ} \mathrm{C}$ :

$$
2 \mathrm{UO}_{2}+5 \mathrm{NH}_{4} \mathrm{HF}_{2} \rightarrow 2 \mathrm{NH}_{4} \mathrm{UF}_{5}+3 \mathrm{NH}_{3}+4 \mathrm{H}_{2} \mathrm{O}
$$

Nesta temperatura, somente 8 horas são necessárias para efetuar a fluoração. O material é carregado em um container de alumínio com fluoreto de cálcio e aquecido em um forno de alumínio. O forno é provido de um tubo de condensação com válvula de alívio, que libera a água e amônia da reação de fluoração para um reservatório e retém o excesso de bifluoreto sublimado.

Durante a fluoração e/ou decomposição, a formação de $\mathrm{UO}_{2} \mathrm{~F}_{2}$ provavelmente ocorre, porém não parece ser significante, julgando a análises do $\mathrm{UF}_{4}$ e a eficiência da redução na etapa seguinte.

Em uma segunda etapa do processo, o $\mathrm{NH}_{4} \mathrm{UF}_{5}$ é decomposto a UF 4 sob vácuo, ocorrendo paralelamente a destilação do $\mathrm{NH}_{4} \mathrm{~F}$ : 
$\mathrm{NH}_{4} \mathrm{UF}_{5} \rightarrow \mathrm{UF}_{4}+\mathrm{NH}_{4} \mathrm{~F}$

O forno é provido de um vaso cilíndrico em aço inox contido em outro vaso externo em aço doce, entre um e outro temos uma fita de aquecimento elétrico. O vácuo é mantido pela utilização de gaxetas de borracha entre as faces planas do reator de aço inox refrigerado a água.

$\mathrm{O} \mathrm{NH}_{4} \mathrm{UF}_{5}$ é colocado em bandejas de alumínio, com uma camada de aproximadamente 2" de espessura, coberto com fluoreto de cálcio. Estas bandejas são suspensas em um suporte, o qual também atua como proteção contra a queda de cristais de $\mathrm{NH}_{4} \mathrm{~F}$ que podem se cristalizar na parte superior.

O programa de aquecimento para a decomposição do $\mathrm{NH}_{4} \mathrm{UF}_{5}$ é apresentado na TAB. 9:

Tabela 9 - Programa de aquecimento para a decomposição do $\mathrm{NH}_{4} \mathrm{UF}_{5}$ utilizado pelo Centre d'Etudes pouer lês Applications de l'Energie Nucléaire, na Bélgica.

\begin{tabular}{|c|c|c|c|}
\hline Estágio & Temperatura $^{\circ} \mathbf{C}$ & Tempo (h) & Produto de decomposição \\
\hline a & Até 350 & 8 & $\mathrm{NH}_{3}$ \\
\hline b & 350 a 500 & 4 & $\mathrm{NH}_{4} \mathrm{~F}$ \\
\hline c & 500 & 4 & $\mathrm{NH}_{4} \mathrm{~F}$ \\
\hline
\end{tabular}

No estágio (a) toda amônia é eliminada.

No estágio (b) o nitrogênio é reduzido para 500 ppm.

No último estágio (c), hidrogênio à aproximadamente $600 \mathrm{~mm}$ de pressão é adicionado ao sistema para evitar a formação de $\mathrm{UO}_{2} \mathrm{~F}_{2}$, e o nitrogênio é reduzido a 5 ppm.

O pó de $\mathrm{UF}_{4}$ obtido apresenta um tamanho médio de partícula de 100 mesh, que não aglomera e não adere nas paredes da bandeja.

\subsubsection{Preparação de $\mathrm{UF}_{4}$ pela reação de $\mathrm{UO}_{3}$ com bifluoreto de amônio}

$\mathrm{O} \mathrm{UF}_{4}$ pode ser preparado pela reação do fluoreto ou bifluoreto de amônio com $\mathrm{UO}_{3}$ de acordo com a equação:

$3 \mathrm{UO}_{3}+6 \mathrm{NH}_{4} \mathrm{HF}_{2} \leftrightarrow 3 \mathrm{UF}_{4}+9 \mathrm{H}_{2} \mathrm{O}+4 \mathrm{NH}_{3}+\mathrm{N}_{2}$

Embora os Estados Unidos tenham sido dos primeiros a estudar 0 processo [53], o Canadá é o país que mais desenvolveu este processo [51,54]. 
Contudo, atualmente existem no IPEN-CNEN/SP duas rotas fundamentadas para a produção de UF4 [55,56]:

- Preparação de UF4 via aquosa, a partir de sais de $\mathrm{U}^{+6}$ fazendo uso de Cloreto de estanho II.

$$
\mathrm{UO}_{2} \mathrm{~F}_{2}(\mathrm{aq})+\mathrm{SnCl}_{2}(\mathrm{~s})+4 \mathrm{HF}(\mathrm{aq}) \leftrightarrow \mathrm{UF}_{4}+\mathrm{SnCl}_{2} \mathrm{~F}_{2}+2 \mathrm{H}_{2} \mathrm{O}
$$

- Preparação de $\mathrm{UF}_{4}$ via seca, a partir de $\mathrm{UO}_{2}$ (Hidrofluoretação)

$\mathrm{UO}_{2}(\mathrm{~s})+4 \mathrm{HF}(\mathrm{aq}) \leftrightarrow \mathrm{UF}_{4}(\mathrm{~s})+2 \mathrm{H}_{2} \mathrm{O}$ 


\section{MATERIAIS E MÉTODOS}

\subsection{Técnicas de Caracterização Utilizadas}

Os efluentes e compostos obtidos neste estudo foram caracterizados química e fisicamente empregando-se as técnicas descritas a seguir.

\subsubsection{Voltametria de gota pendente de $\mathrm{Hg}$}

Nos efluentes, os teores de urânio foram determinados pela técnica voltamétrica de gota pendente de mercúrio, onde o urânio é oxidado a $\mathrm{U}(\mathrm{VI})$ com ácido nítrico concentrado. Posteriormente é registrada uma curva de potencial versus corrente de uma alíquota da amostra, entre 0 e - 0,3V X ECS, utilizando um microeletrodo de mercúrio. Determina-se o teor de urânio pelo procedimento de adição padrão [57].

O equipamento utilizado foi um Polarógrafo Princeton Applied Research - PAR, modelo 174 com eletrodos de gota pendente de mercúrio.

\subsubsection{Volumetria e gravimetria - composição química do $\mathrm{UF}_{4}$}

Este método é usado para determinação de $U_{2} \mathrm{~F}_{2}, \cup_{2}$, e UF $\mathrm{F}_{4} \mathrm{O}$ método[58] analisa, em seqüência, os produtos mais prováveis existentes juntamente com o $\mathrm{UF}_{4}$.

A determinação de $\mathrm{UO}_{2} \mathrm{~F}_{2}$ se baseia no princípio de que apenas 0 fluoreto de uranilo é solúvel em etanol. $\mathrm{O} \cup_{2} \mathrm{~F}_{2}$ é dissolvido com etanol e separado por filtração em placa porosa, após a evaporação do álcool e destruição de eventual matéria orgânica, o urânio é determinado volumétricamente por titulação com dicromato de potássio.

A massa residual na placa $\left(\mathrm{UF}_{4}+\mathrm{UO}_{2}\right)$ é tratada com oxalato de amônio a quente, no qual apenas ${ }^{\circ} \mathrm{UF}_{4}$ é solúvel. $\mathrm{O}$ resíduo $\left(\mathrm{UO}_{2}\right.$ e eventualmente $\mathrm{UO}_{3}$ e $\mathrm{U}_{3} \mathrm{O}_{8}$ ) é lavado, filtrado, calcinado como $\mathrm{U}_{3} \mathrm{O}_{8}$, sendo assim 
analisado o insolúvel em oxalato de amônio (IOA), correspondendo praticamente ao $\mathrm{UO}_{2}$ não convertido.

No filtrado determina-se o urânio para o conhecimento do conteúdo de $\mathrm{UF}_{4}$ na amostra, por titulação com dicromato de potássio ou evaporando a solução e calcinando a $\mathrm{U}_{3} \mathrm{O}_{8}$.

Para determinar o urânio total, faz-se a dissolução completa do material, elimina-se o flúor, além de eventual matéria orgânica, e depois determina-se o teor de urânio por titulação com dicromato de potássio[53]. Algumas determinações podem ser feitas gravimetricamente, dependendo da situação, por calcinação do produto diretamente a $\mathrm{U}_{3} \mathrm{O}_{8}$.

\subsubsection{Microdifusão da amônia}

O método para a determinação do teor de amônia nos efluentes, tem como princípio a microdifusão da amônia que se desloca da solução (colocada em uma célula de microdifusão de Conway) por tornar-se o meio fortemente básico e desse modo exercer uma tensão que facilita o escape da amônia. $A$ amônia liberada reage com uma solução de ácido sulfúrico, colocada no compartimento interno da célula, que não exerce tensão alguma para a absorção da amônia. O excesso de ácido sulfúrico na solução que não reage com a amônia é titulado com uma solução padronizada de hidróxido de sódio [30].

\subsubsection{Eletrodo de íon seletivo}

Os teores de fluoreto nos efluentes foram determinados por meio de eletrodos seletivos conectados a um analisador de íons, após a separação dos cátions por troca iônica. O eletrodo seletivo, com dispositivo sensível ao íon $\mathrm{F}^{-}$, quando submerso na solução, desenvolve um potencial elétrico que é provocado pela atividade do íon, que é proporcional à concentração do íon livre na solução diluída. $\mathrm{O}$ aparelho analisador de íons, mede esse potencial contra um potencial constante de referência, e uma vez calibrado fornece o resultado já como concentração do íon na solução [59].

As análises foram realizadas em um Analisador de íons com 2 canais, modelo E920 - marca ORION. 


\subsubsection{Difração de Raios $X$}

A utilização da técnica de difração de raios $X$ tem como finalidade a identificação de fases dos compostos obtidos. Esta técnica consiste em incidir um feixe de raios $X$ de comprimento de onda $\lambda$ sobre a amostra, variando o ângulo de incidência $(\theta)$, de maneira que o ângulo de incidência iguale-se ao ângulo de reflexão, ou seja, quando a Lei de Bragg é obedecida, ocorre um registro gráfico referente a um dos picos de difração [30].

As análises foram realizadas num difratômetro de raios $x$ com monocromador (Rigato Multiflex), com tubo de cobre $\alpha(\lambda=0,154178 \mathrm{~nm})$. A interpretação dos difratogramas foi feita segundo procedimentos da Powder Diffraction File.

\subsubsection{Microscopia Eletrônica de varredura}

Observação da morfologia, tamanho do aglomerado, da porosidade na superfície das partículas dos compostos de urânio obtido.

A microscopia eletrônica de varredura é uma técnica que tem sido amplamente utilizada para a avaliação da geometria e dimensão dos aglomerados e das partículas primárias. Este aspecto é decorrente do fato de que o microscópio eletrônico de varredura consiste em um canhão emissor de elétrons, que dirigidos à superfície de uma amostra por lentes magnéticas, produzem elétrons secundários. Estes são captados pelo campo elétrico de um coletor e utilizados na formação da imagem. Enquanto o feixe eletrônico varre a superfície da amostra, um cinescópio reproduz sua imagem com um efeito tridimensional [30].

As amostras de $\mathrm{UF}_{4}$ foram dispersas a seco num suporte de alumínio e recobertas com ouro. A análise foi efetuada num microscópio eletrônico de varredura, marca Philips, modelo XL30.

\subsubsection{Adsorção gasosa (B.E.T.)}

A adsorsão gasosa foi utilizada para a determinação da área de superfície específica das amostras de $\mathrm{UF}_{4}$. Esta técnica consiste na medida das alterações sofridas pelo nitrogênio, quando uma amostra é submetida a variações 
de pressão na temperatura do nitrogênio líquido. Para relacionar a adsorção física das moléculas de nitrogênio sobre o pó, com a área de superfície específica do mesmo, são utilizadas as equações matemáticas elaboradas por Brunauer, Emmett e Teller (B.E.T.) [30].

Utilizou-se um equipamento QUANTA CHROME, modelo Nova 1000 .

\subsubsection{Análise térmica diferencial}

Comportamento térmico dos compostos de urânio obtidos. Diferenças de temperatura entre um material chamado de referência e o material em estudo produzem diferenças de potencial (ou tensão), que são registradas como sinais proporcionais à variação de temperatura, ao longo do tempo. Como alternativa, pode-se realizá-la simultaneamente a análise termogravimétrica, que toma por base o mesmo princípio, só que o sinal gerado é proporcional à variação de massa, ao invés da temperatura, entre ambos os materiais.

Utilizamos o equipamento da SETARAM, modelo Setsys 16/18.

\subsubsection{Espalhamento de laser - Distribuição do tamanho de partículas}

Mede a distribuição granulométrica em função do espalhamento de luz, de um feixe de laser. Quando a amostra desagregada por ultra-som, passa pela célula, é atravessada pelo feixe de laser que incide em um detector de silício. $\mathrm{O}$ resultado é fornecido em um histograma.

O aparelho utilizado foi o CILAS modelo 1064.

\subsubsection{Picnometria de Hélio - Determinação da massa específica}

A massa específica foi obtida pelo método picnométrico, baseado na determinação do volume de uma massa conhecida de pó pelo deslocamento de gás (Hélio) em função da variação de pressão[60].

Aplica-se uma pressão conhecida de gás Hélio no compartimento onde foi colocada a amostra do pó, após a estabilização desta pressão (P1), abre-se uma válvula de expansão, liberando o gás para o compartimento de expansão, onde haverá uma nova estabilização de pressão (P2). 
A densidade da amostra (D) é determinada através da seguinte equação:

$$
D=\frac{m}{\text { Vcell }-\frac{\text { Vexp }}{\frac{P 1}{P 2}-1}}
$$

Onde:

$\mathrm{m}=$ massa da amostra;

Vcell = volume do compartimento da amostra;

Vexp = volume do compartimento de expansão;

$\mathrm{P} 1$ = pressão no compartimento da amostra;

P2 = pressão após a expansão do gás

O aparelho utilizado para a análise é o AccuPyc 1330 da Micrometrics Instrument Corporation, que é um picnômetro de deslocamento de gás (Hélio), capaz de medir o volume e a densidade de objetos e partículas sólidas.

\subsubsection{Determinação da densidade}

A densidade solta foi obtida de acordo com o método padrão (Norma ASTM - B 212 - 48), que consiste em encher sob determinadas condições, um recipiente de volume conhecido com o pó e pesar essa quantidade, calculando-se em seguida a relação massa/volume [61].

A densidade batida consiste em colocar uma quantidade conhecida de pó em uma proveta graduada, deixando-a cair suavemente 20 vezes, de uma altura de $15 \mathrm{~mm}$, sobre a bancada do laboratório, calculando-se em seguida a relação massa/volume. Utilizou-se proveta de $25 \mathrm{~mL}$ [56].

Ambas as densidades são expressas em g. $\mathrm{cm}^{-3}$. 


\subsection{Equipamentos}

\subsubsection{Reator de cristalização}

A FIG. 4, ilustra o reator de cristalização, onde a solução fluoretada (filtrado VIII) foi concentrada até a cristal ização do bifluoreto de amônio $\left(\mathrm{NH}_{4} \mathrm{HF}_{2}\right)$.

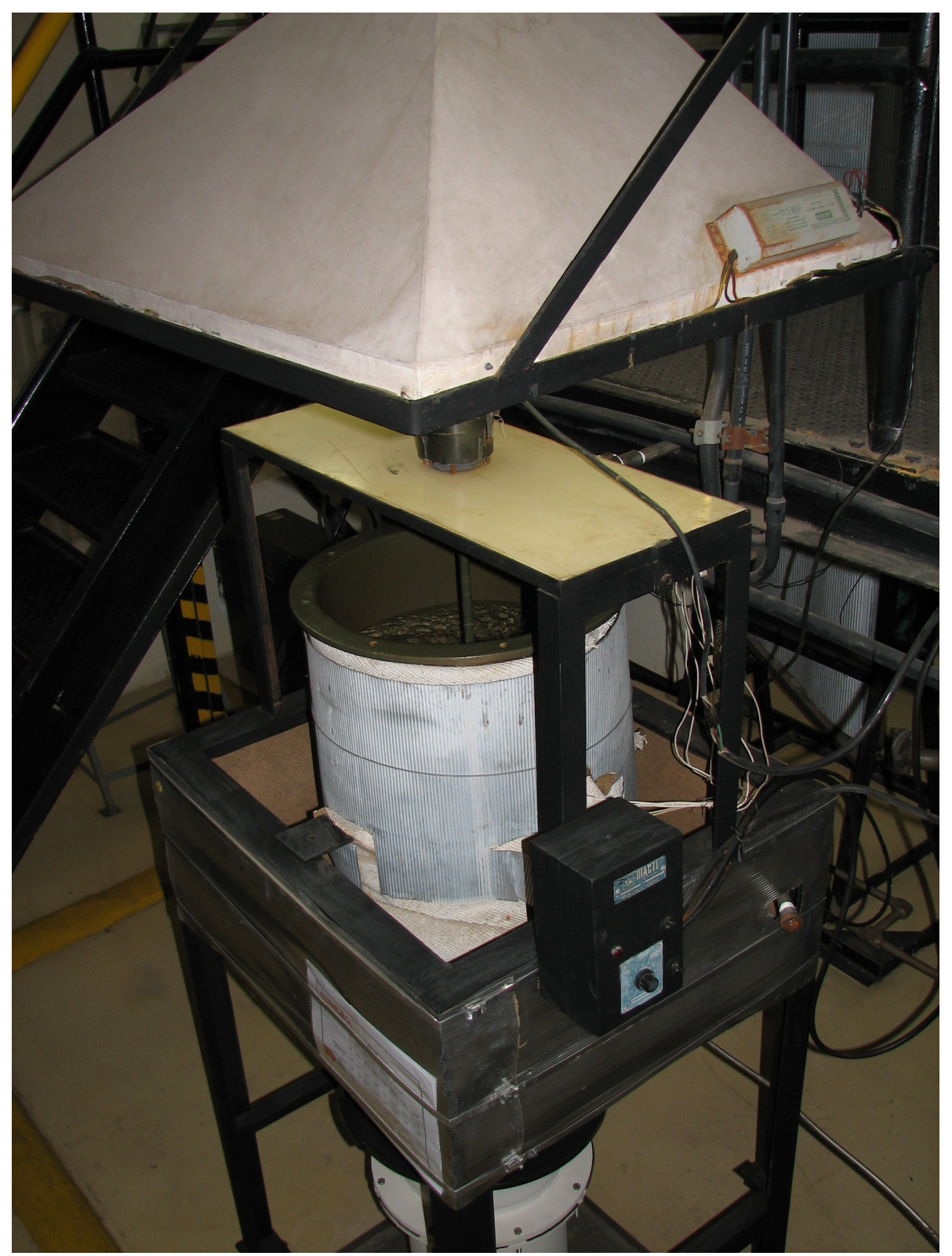

Figura 4 - Reator químico com camisa de aquecimento a vapor, revestido em teflon. 


\subsubsection{Forno de Fluoração}

A FIG. 5, ilustra o forno resistivo, onde foram realizados os ensaios de fluoração dos óxidos de urânio, conforme a reação:

$$
2 \mathrm{UO}_{2}+5 \mathrm{NH}_{4} \mathrm{HF}_{2} \rightarrow 2 \mathrm{NH}_{4} \mathrm{UF}_{5}+4 \mathrm{H}_{2} \mathrm{O}+3 \mathrm{NH}_{3}
$$

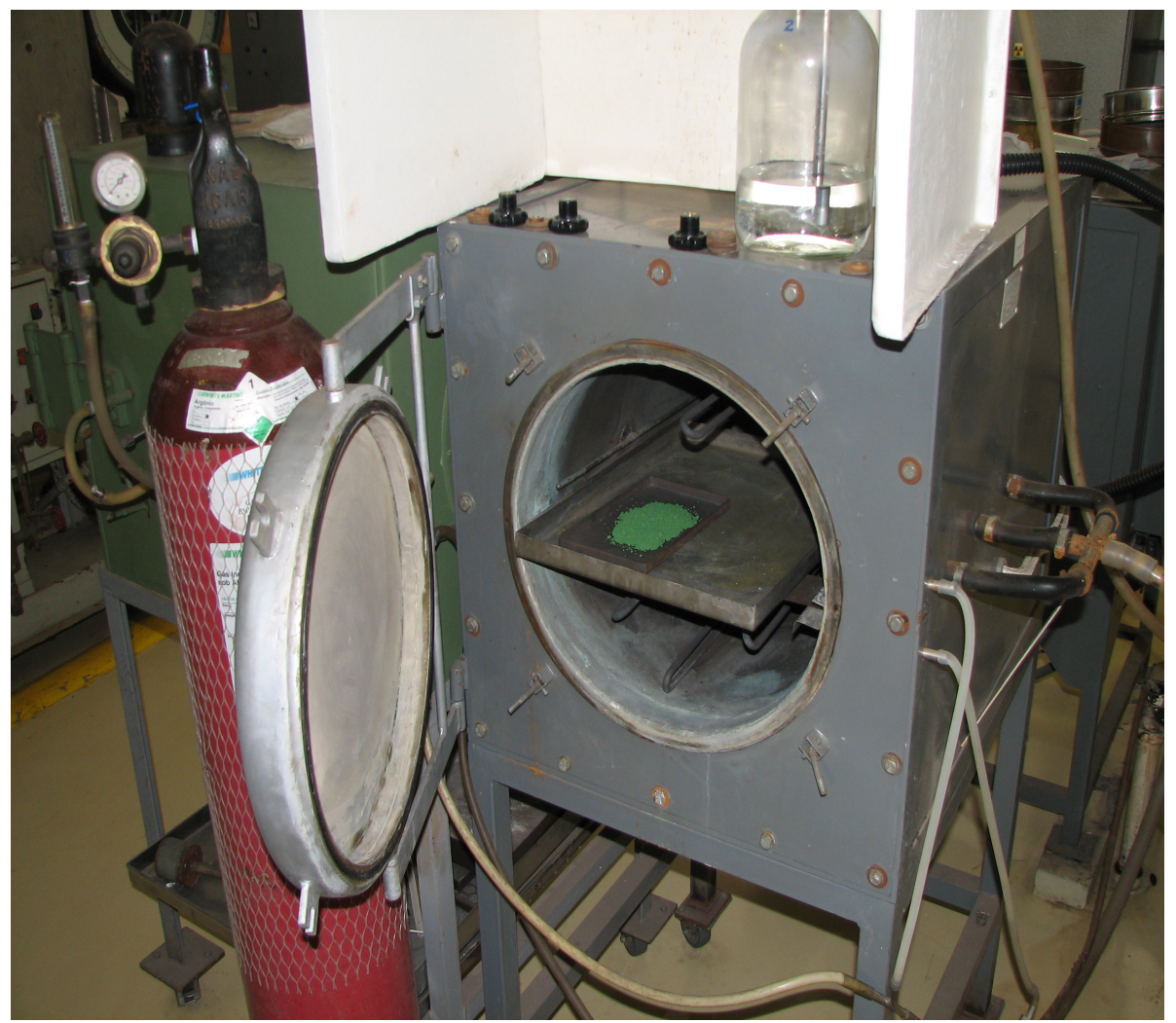

Figura 5 - Forno resistivo Grion para temperaturas até $400{ }^{\circ} \mathrm{C}$.

\subsubsection{Forno de Decomposição.}

A FIG. 6, ilustra o forno resistivo, onde foram realizados os ensaios de decomposição à $\mathrm{UF}_{4}$, conforme a reação:

$$
\mathrm{NH}_{4} \mathrm{UF}_{5(\mathrm{~s})} \rightarrow \mathrm{UF}_{4(\mathrm{~s})}+\mathrm{NH}_{4} \mathrm{~F}_{(\mathrm{g})}
$$




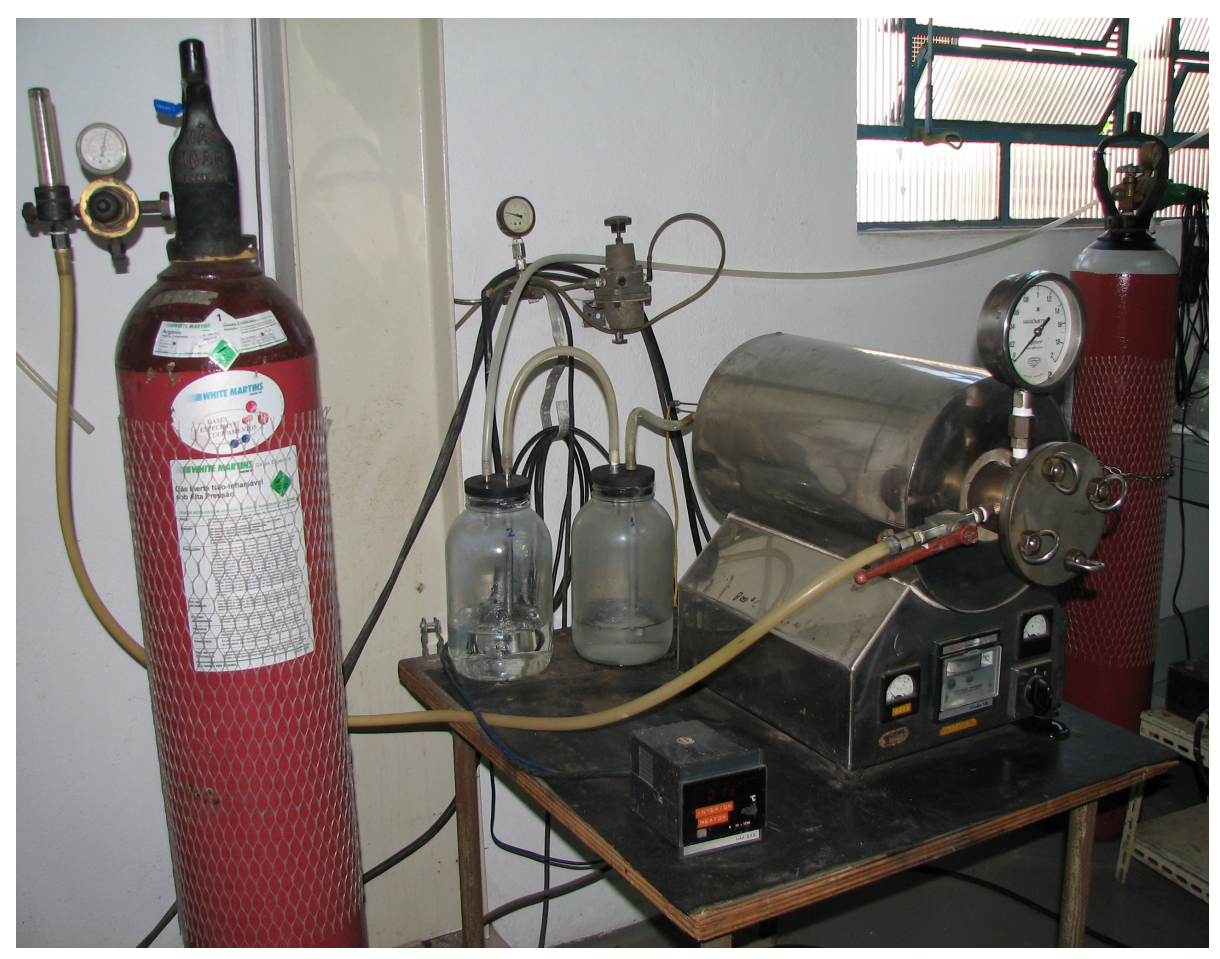

Figura 6 - Forno resistivo F.E.L. para temperaturas até $1000^{\circ} \mathrm{C}$.

\subsection{Procedimento experimental}

\subsubsection{Caracterização química do efluente fluoretado (filtrado VIII)}

Iniciou-se o estudo a partir da caracterização química dos efluentes fluoretados proveniente da reconversão do $U_{6}$, em especial, o efluente do APOFU empregando técnicas analíticas na caracterização das amostras coletadas. O filtrado consiste basicamente de uma solução contendo elevada concentração de íons amônio $\left(\mathrm{NH}_{4}^{+}\right)$, fluoreto( $\left.\mathrm{F}^{-}\right)$e baixo teor de urânio.

\subsubsection{Cristalização do $\mathrm{NH}_{4} \mathrm{HF}_{2}$}

Foram realizados testes preliminares com o objetivo de verificar a viabilidade da obtenção do bifluoreto de amônio $\left(\mathrm{NH}_{4} \mathrm{HF}_{2}\right)$, a partir da concentração do efluente proveniente da precipitação do tetrafluoreto de urânio (Filtrado III) via úmida, processo que usa como redutor o cloreto estanoso.

A solução fluoretada gerada, ou seja, o filtrado do $U_{4}$, foi concentrado na temperatura de $80^{\circ} \mathrm{C}$, em um becker de teflon, visando a recuperação do $\mathrm{NH}_{4} \mathrm{~F}$ por meio da cristalização do bifluoreto de amônio. Durante o processo, foi 
borbulhado amônia $\left(\mathrm{NH}_{3}\right)$ mantendo-se o pH entre 8 e 9. Após concentrado, aproximadamente 1 litro do efluente, abaixo de $20 \%$ do volume inicial, surgiram os primeiros cristais do sal. Após o resfriamento e a cristalização do sal, o produto foi filtrado e lavado com álcool para reduzir a umidade.

Foram realizados testes de obtenção do bifluoreto de amônia $\left(\mathrm{NH}_{4} \mathrm{HF}_{2}\right.$ ), a partir da concentração do efluente (filtrado VIII - FIG. 3) proveniente da precipitação do APOFU fazendo o uso de um reator químico revestido com teflon, sob agitação e temperatura.

- Solução inicial: $\mathrm{NH}_{4} \mathrm{~F}$

$$
2 \mathrm{NH}_{4} \mathrm{~F}+\mathrm{H}_{2} \mathrm{O} \stackrel{95^{\circ} \mathrm{C}}{\longrightarrow} \mathrm{NH}_{4} \mathrm{HF}_{2} \text { (cristalizado) }+\mathrm{NH}_{4} \mathrm{OH}
$$

\subsubsection{Fluoração}

Foram realizados ensaios de fluoração de compostos de urânio $\left(\mathrm{UO}_{2} \mathrm{e}\right.$ $\mathrm{U}_{3} \mathrm{O}_{8}$ ) utilizando como reagente o bifluoreto de amônia (proveniente do filtrado VIII - FIG. 3) conforme reação abaixo:

- Reação de fluoração:

$$
2 \mathrm{UO}_{2}+5 \mathrm{NH}_{4} \mathrm{HF}_{2} \rightarrow 2 \mathrm{NH}_{4} \mathrm{UF}_{5}+4 \mathrm{H}_{2} \mathrm{O}+3 \mathrm{NH}_{3} .
$$

Nos ensaios de fluoração o $\mathrm{NH}_{4} \mathrm{HF}_{2}$ foi adicionado aos óxidos de urânio com $20 \%$ de excesso em relação ao cálculo estequiométrico, e submetido à uma temperatura de $150^{\circ} \mathrm{C}$, porém, variamos o tempo em 8, 12, 16, 24 e 36 horas.

\subsubsection{Decomposição}

Foram realizados experimentos de decomposição do $\mathrm{NH}_{4} \mathrm{UF}_{5}$ visando a obtenção do $\mathrm{UF}_{4}$.

- reação de decomposição

$$
\mathrm{NH}_{4} \mathrm{UF}_{5(\mathrm{~s})} \rightarrow \mathrm{UF}_{4(\mathrm{~s})}+\mathrm{NH}_{4} \mathrm{~F}_{(\mathrm{g})}
$$

Nos ensaios de decomposição foram estudadas a temperatura (400 e $\left.500^{\circ} \mathrm{C}\right)$ e tempo (2, 4 ou 6 horas) de reação mais adequadas, fazendo o uso de atmosfera de argônio grau analítico 5.0. 
4.3.5. Caracterização do produto obtido - UF 4

$\mathrm{O} \mathrm{UF}_{4}$ foi caracterizado química e fisicamente empregando as técnicas de volumetria e gravimetria, difratometria de raios $x$, microscopia eletrônica de varredura, espalhamento laser e área de superfície especifica por adsorção gasosa (BET). 


\section{RESULTADOS E DISCUSSÕES}

\subsection{Caracterização química do efluente fluoretado (filtrado VIII)}

O efluente de APOFU (Filtrado VIII - FIG 3), utilizado neste trabalho, foi caracterizado quimicamente e os resultados foram apresentados na TAB. 10.

Tabela 10 - Composição do filtrado do APOFU utilizado.

\begin{tabular}{|c|c|}
\hline Íon & Concentração média \\
\hline $\mathrm{U}^{+6}$ & $2.03 \mathrm{mg} \cdot \mathrm{L}^{-1}$ \\
\hline $\mathrm{NH}^{+}{ }_{4}$ & $80.1 \mathrm{~g} \cdot \mathrm{L}^{-1}$ \\
\hline $\mathrm{F}^{-}$ & $110 \mathrm{~g} \cdot \mathrm{L}^{-1}$ \\
\hline $\mathrm{CO}_{3}{ }^{=}+\mathrm{HCO}_{3}{ }^{-}$ & $0.34 \mathrm{~g} \cdot \mathrm{L}^{-1}$ \\
\hline \hline densidade & $1.084 \mathrm{~g} \cdot \mathrm{cm}^{-3}$ \\
\hline $\mathrm{pH}$ & 8.5 \\
\hline
\end{tabular}

O resultado confirmou no efluente de APOFU, grande concentração de amônia e fluoretos, e mesmo em relação à concentração de urânio, encontrou-se um valor cem vezes maior que o máximo admissível pelo CONAMA (TAB. 1), para descarte. Portanto, é viável e conveniente o reaproveitamento deste resíduo líquido.

\subsection{Cristalização do $\mathrm{NH}_{4} \mathrm{HF}_{2}$}

Nos estudos preliminares a partir da concentração do efluente proveniente da precipitação do tetrafluoreto de urânio via úmida (Filtrado III, FIG. 3), a caracterização do sal obtido, pela técnica de difração de raios $X$, que determina os principais constituintes do composto, não detectou a presença do $\mathrm{NH}_{4} \mathrm{HF}_{2}$ (bifluoreto de amônio). Devido a grande concentração de íons $\mathrm{Sn}^{2+}$ e $\mathrm{Cl}^{-}$ presente neste efluente, os compostos mais prováveis encontrados foram $\mathrm{NH}_{4} \mathrm{Cl}$, $\mathrm{Sn}\left(\mathrm{NH}_{3}\right)_{2} \mathrm{~F}_{4}$ e $\left(\mathrm{Sn}_{2} \mathrm{O}_{2} \mathrm{~F}_{4}\right) \mathrm{Sn}_{2}$. A utilização deste sal como agente fluoretante foi descartada. 
No estudo de cristalização a partir do efluente do APOFU (FiltradoVIII, FIG 3), a solução fluoretada $\left(\mathrm{NH}_{4} \mathrm{~F}\right)$ passou por um processo de concentração sob aquecimento a $95^{\circ} \mathrm{C}$, até aproximadamente $25 \%$ do volume inicial, obtendo-se após o resfriamento, a cristalização do $\mathrm{NH}_{4} \mathrm{HF}_{2}$ (bifluoreto de amônio). O produto foi lavado com álcool etílico para reduzir a umidade. $\mathrm{O} \mathrm{NH}_{4} \mathrm{HF}_{2}$ obtido foi caracterizado por difração de raios X e o resultado é apresentado na FIG. 7.

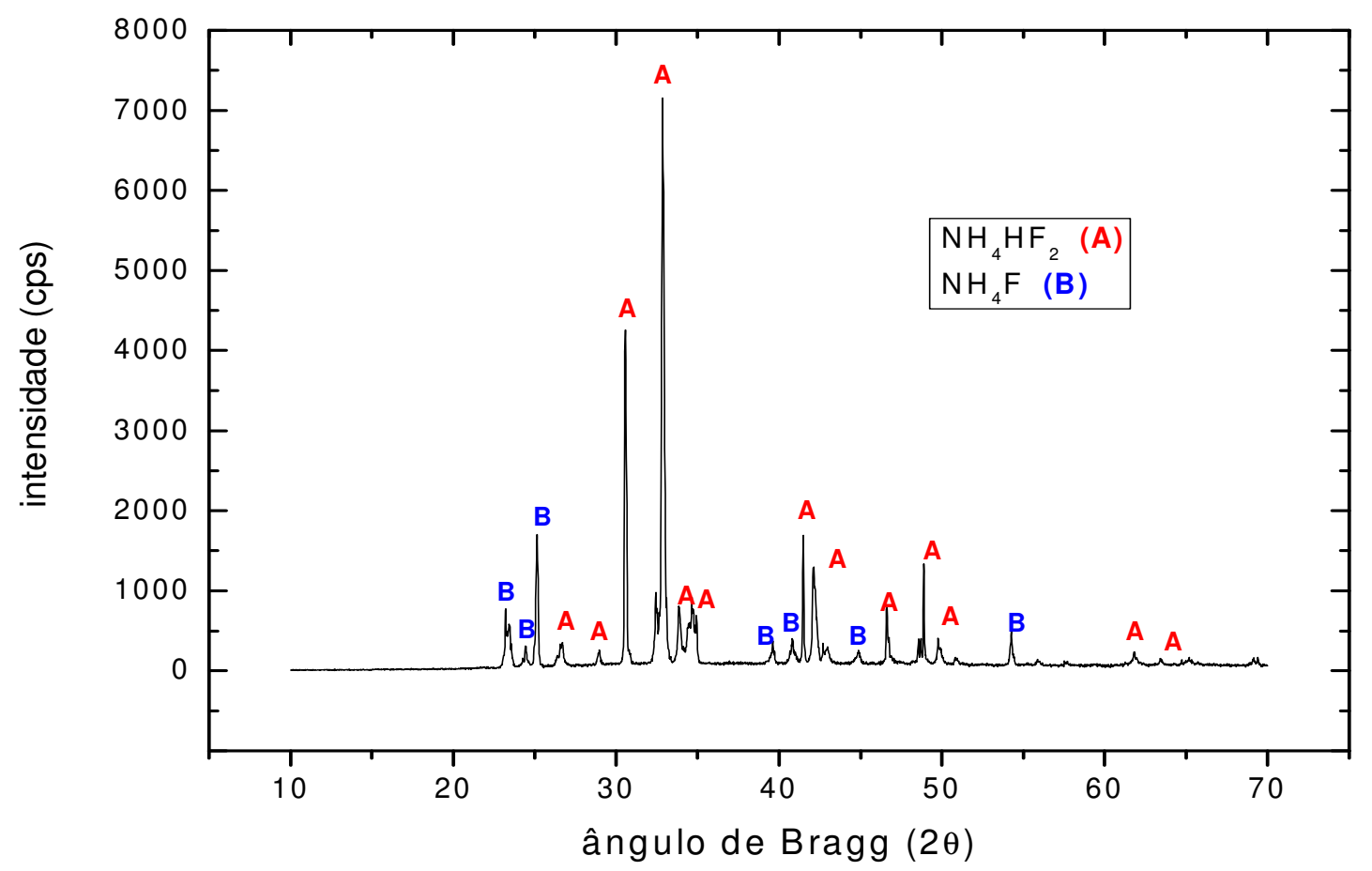

Figura 7 - Difratograma de raios $x$ do $\mathrm{NH}_{4} \mathrm{HF}_{2}$ obtido do processamento do filtrado VIII.

O resultado encontrado no difratograma de raios $x$ comprovou a viabilidade da obtenção de um sal fluoretante a partir do efluente do APOFU. A cristalização do composto $\mathrm{NH}_{4} \mathrm{HF}_{2}$ foi comprovada pela ficha JCPDS 12-0302 do catálogo da Powder Diffraction File [62], e apesar da presença em pequena quantidade de fluoreto de amônio $\left(\mathrm{NH}_{4} \mathrm{~F}\right)$, segundo a ficha JCPDS 35-0758 do catálogo da Powder Diffraction File [62], este é tão eficiente quanto o bifluoreto em relação a fluoração. No difratograma não é possível identificar a presença de compostos de urânio, provavelmente devido a baixa concentração. 


\subsection{Fluoração}

Vários experimentos foram realizados, utilizando-se como materiais de partida o bifluoreto de amônio $\left(\mathrm{NH}_{4} \mathrm{HF}_{2}\right)$ contendo urânio, obtido a partir do filtrado da precipitação do APOFU e um lote de octóxido de urânio $-\mathrm{U}_{3} \mathrm{O}_{8}$ proveniente da recuperação de placas.

Para todos ensaios de fluoração fixou-se a temperatura em $150^{\circ} \mathrm{C}$, um pouco maior do que a temperatura de fusão do $\mathrm{NH}_{4} \mathrm{HF}_{2}$ [63] que é de $124,6^{\circ} \mathrm{C}$, ou seja, suficiente para que a reação ocorra e a água formada seja facilmente liberada, evitando ao máximo a formação do $\mathrm{UO}_{2} \mathrm{~F}_{2}$.

Nestes experimentos, o $\mathrm{NH}_{4} \mathrm{HF}_{2}$ foi adicionado ao $\mathrm{U}_{3} \mathrm{O}_{8}$ com $20 \%$ em excesso de bifluoreto de amônio em relação ao cálculo estequiométrico, e submetido à uma temperatura de $150^{\circ} \mathrm{C}$, porém, variou-se o tempo em 8,16 ou 24 horas. Nestes experimentos utilizou-se sistema fechado, ou seja, a mistura foi colocada em um reator de teflon e posteriormente no interior do forno. A FIG. 8 apresenta um desenho esquemático do ensaio de fluoração.

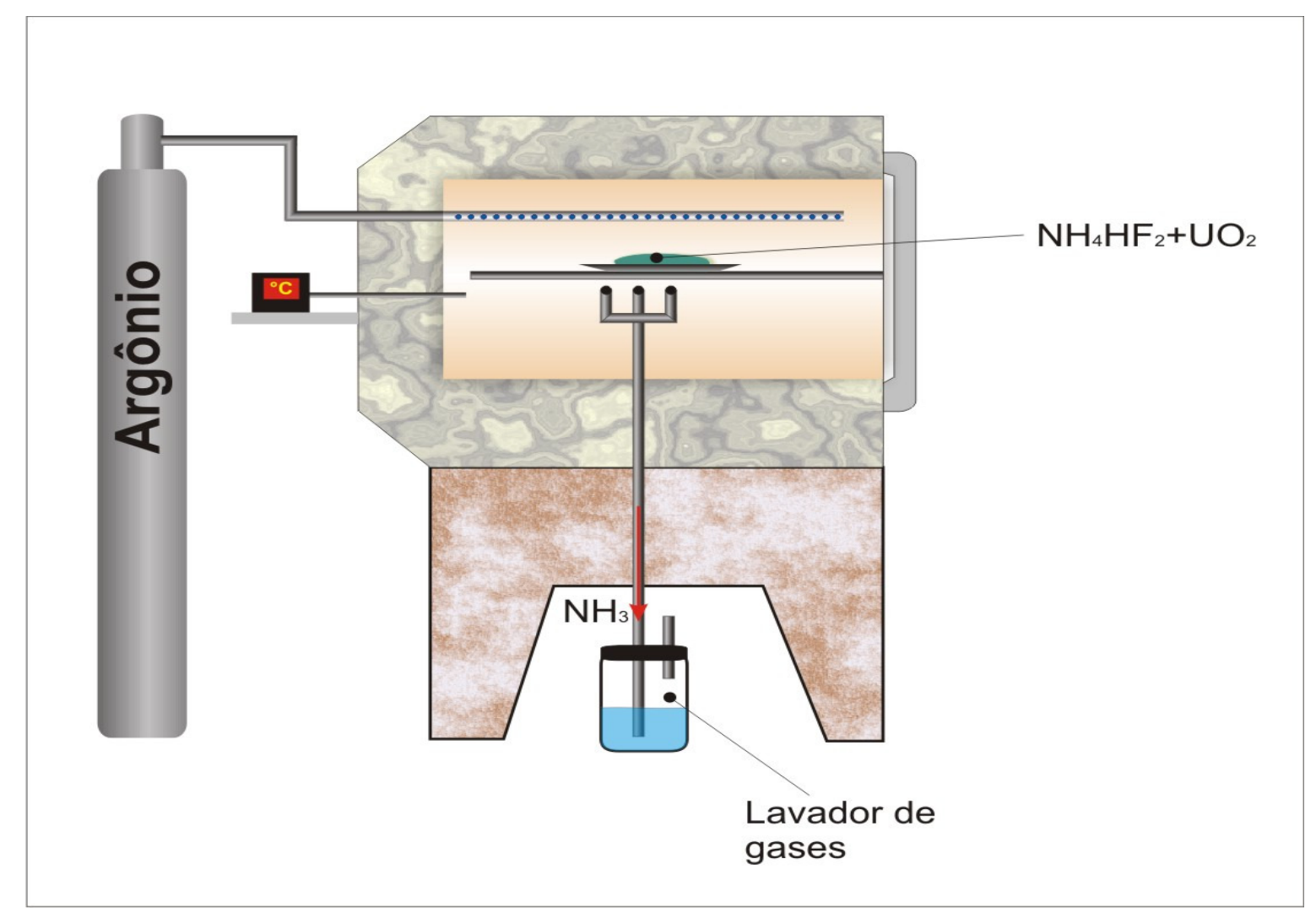

Figura 8 - Sistema de fluoração 
Após ensaios de fluoração foram retiradas amostras para análise de difração de raios $X$. Tomando-se como referência a revisão bibliográfica disponível, em especial as que tratam especificamente da obtenção de $\mathrm{UF}_{4}$ via seca que utiliza o bifluoreto de amônio [28,51,52,53,54], esperava-se obter o sal $\mathrm{NH}_{4} \mathrm{UF}_{5}$, porém os difratogramas de raios $X$ analisados não comprovaram a presença deste sal. Após a comparação dos difratogramas de raios $\mathrm{x}$ obtidos com as fichas padrões de compostos similares, concluiu-se que o composto de urânio, obtido após a fluoração, é o $\left(\mathrm{NH}_{4}\right)_{7} \mathrm{U}_{6} \mathrm{~F}_{31}$, equivalente à ficha JCPDS 16-756 do catálogo da Powder Diffraction File [62]. O difratograma de raios $x$ do $\left(\mathrm{NH}_{4}\right)_{7} \mathrm{U}_{6} \mathrm{~F}_{31}$ obtido, é apresentado na FIG. 9.

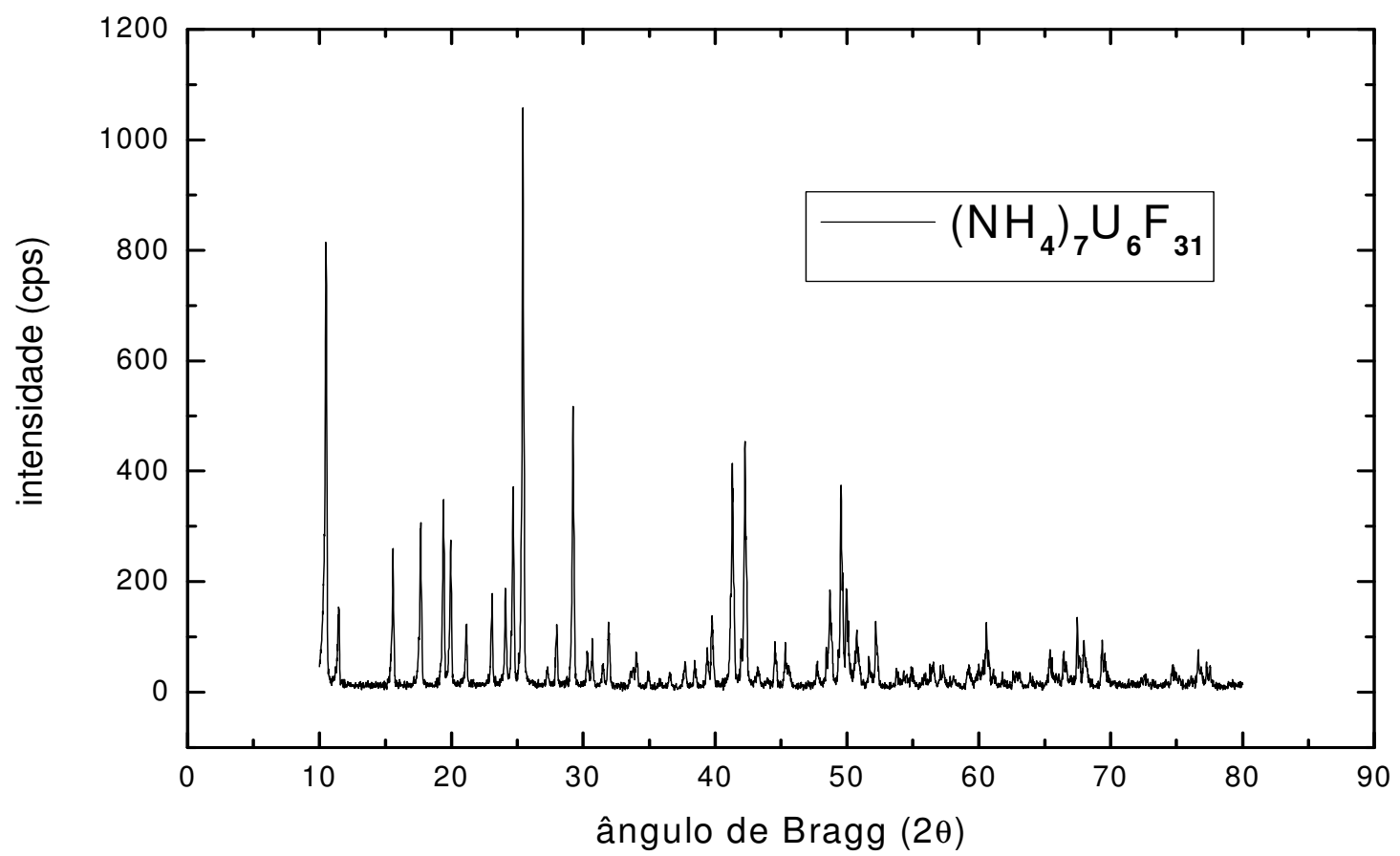

Figura 9 - Difratograma de raios $\mathrm{x}$, típico do $\left(\mathrm{NH}_{4}\right)_{7} \mathrm{U}_{6} \mathrm{~F}_{31}$ obtido após a fluoração.

O resultado nos levou a definir uma nova reação de fluoração do $\mathrm{UO}_{2}$ via seca com $\mathrm{NH}_{4} \mathrm{HF}_{2}$ :

$12 \mathrm{UO}_{2}+31 \mathrm{NH}_{4} \mathrm{HF}_{2} \rightarrow 2\left(\mathrm{NH}_{4}\right)_{7} \mathrm{U}_{6} \mathrm{~F}_{31}+17 \mathrm{NH}_{3}+24 \mathrm{H}_{2} \mathrm{O}$ 
Toda literatura consultada tratando especificamente de processos que utilizam o $\mathrm{NH}_{4} \mathrm{HF}_{2}$ como agente de fluoração[28,51,52,53,54], demonstram uma reação (11) que apresenta como produto o $\mathrm{NH}_{4} \mathrm{UF}_{5}$.

\subsection{Decomposição}

Estudos preliminares foram realizados, procurando reproduzir os procedimentos encontrados na literatura, sendo que nesta etapa do Processo Belga, o $\mathrm{NH}_{4} \mathrm{UF}_{5}$ é decomposto à $\mathrm{UF}_{4}$ sob vàcuo. Procurou-se montar um sistema adequado para realizar testes de decomposição à vácuo, porém, o equipamento disponível não foi eficiente, sendo que em todos experimentos realizados o composto intermediário sofreu oxidação voltando ao composto inicial, o dióxido de urânio $\left(\mathrm{UO}_{2}\right)$. Tentou-se também utilizar como gás de arraste, uma mistura gasosa industrial de argônio com 10\% de hidrogênio, mas neste caso o grau de pureza do gás não é adequado ao processo, ocorrendo novamente a oxidação à $\mathrm{UO}_{2}$. A alternativa encontrada foi a utilização de argônio grau analítico 5.0, criando uma atmosfera inerte e facilitando o arraste dos subprodutos da decomposição. No primeiro teste nessas condições, uma mistura de $\mathrm{UO}_{2}$ com $\mathrm{NH}_{4} \mathrm{HF}_{2}$ passou 12 horas em fluoração à $150{ }^{\circ} \mathrm{C}$, sendo decomposta por 2 horas à $400^{\circ} \mathrm{C}$ e uma amostra foi caracterizada por difração de raios $\mathrm{X}$, o que comprovou a presença de $U_{4}$.

Em função dos resultados apresentados após a fluoração, onde concluímos que o composto intermediário obtido é $\mathrm{O}\left(\mathrm{NH}_{4}\right)_{7} \mathrm{U}_{6} \mathrm{~F}_{31}$, e não 0 $\mathrm{NH}_{4} \mathrm{UF}_{5}$, como demonstram as reações (12,16 e 19) encontradas na literatura, definimos uma nova reação de decomposição:

$$
\left(\mathrm{NH}_{4}\right)_{7} \mathrm{U}_{6} \mathrm{~F}_{31(\mathrm{~s})} \rightarrow 6 \mathrm{UF}_{4(\mathrm{~s})}+7 \mathrm{NH}_{4} \mathrm{~F}_{(\mathrm{g})}
$$

Posteriormente, foram estudadas a temperatura $\left(400\right.$ e $\left.500^{\circ} \mathrm{C}\right)$ e tempo (2, 4 ou 6 horas) de reação mais adequadas, fazendo o uso de atmosfera de argônio grau analítico 5.0.

A FIG. 10 apresenta um desenho esquemático do sistema para os ensaios de decomposição. 


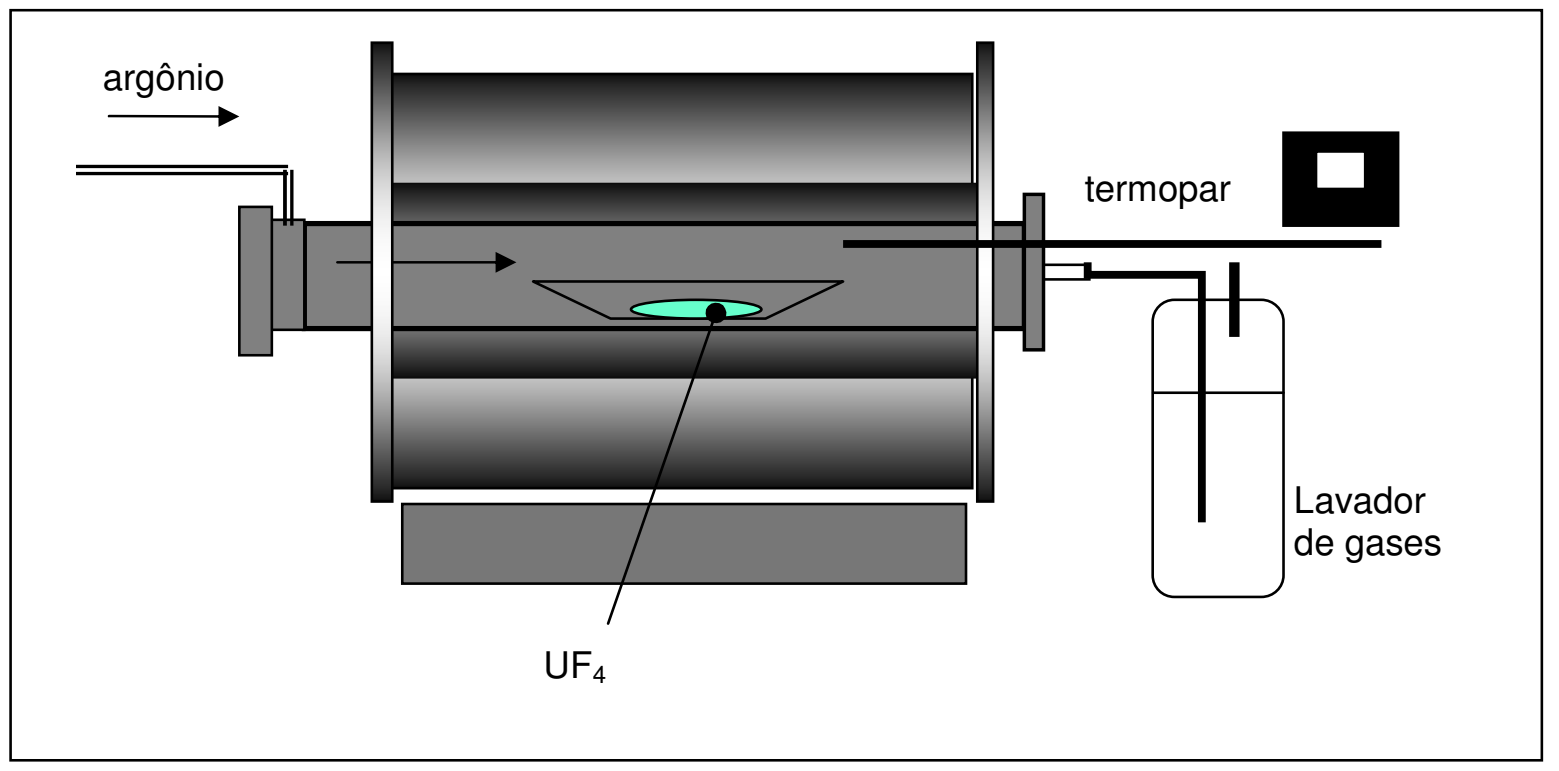

Figura 10 - Sistema de decomposição

Foram preparadas 18 amostras de tetrafluoreto de urânio em condições distintas, apresentadas juntamente com os resultados obtidos, na TAB. 11.

Tabela 11- Ensaios de fluoração e decomposição visando obtenção de $\mathrm{UF}_{4}$ via $\mathrm{U}_{3} \mathrm{O}_{8}$

\begin{tabular}{|c|c|c|c|c|c|c|c|}
\hline \multirow{2}{*}{$\begin{array}{c}\text { IDENTIFICAÇÃO } \\
\text { AMOSTRA }\end{array}$} & \multirow{2}{*}{$\begin{array}{c}\text { FLUORAÇÃO } \\
\text { (horas) }\end{array}$} & \multirow{2}{*}{$\begin{array}{c}\text { TEMPERATURA } \\
\text { DECOMPOSIÇÃO } \\
\left({ }^{\circ} \mathrm{C}\right)\end{array}$} & \multirow{2}{*}{$\begin{array}{c}\text { TEMPO } \\
\text { DECOMPOSIÇÃo } \\
\text { (horas) }\end{array}$} & \multicolumn{4}{|c|}{ ELEMENTO - COMPOSTO (\%) } \\
\hline & & & & $\mathrm{UF}_{4}$ & $\mathrm{UO}_{2} \mathrm{~F}_{2}$ & $\mathrm{UO}_{2}$ & $\mathbf{U}_{\text {TOTAL }}$ \\
\hline 842 & 8 & 400 & 2 & 56,7 & 43,1 & 0,02 & 75,8 \\
\hline 844 & 8 & 400 & 4 & 56.9 & 43,0 & 0,03 & 75,5 \\
\hline 846 & 8 & 400 & 6 & 57,5 & 42,4 & 0,03 & 75,7 \\
\hline 852 & 8 & 500 & 2 & 58,0 & 41,9 & 0,02 & 75,6 \\
\hline 854 & 8 & 500 & 4 & 58,7 & 41,2 & 0,03 & 75,8 \\
\hline 856 & 8 & 500 & 6 & 57,5 & 42,7 & 0,03 & 75,7 \\
\hline 1642 & 16 & 400 & 2 & 57,7 & 42,2 & 0,03 & 75,7 \\
\hline 1644 & 16 & 400 & 4 & 57,4 & 42,5 & 0,03 & 75,6 \\
\hline 1646 & 16 & 400 & 6 & 57,1 & 42,8 & 0,03 & 75,7 \\
\hline 1652 & 16 & 500 & 2 & 56,6 & 43,3 & 0,03 & 75,7 \\
\hline 1654 & 16 & 500 & 4 & 58,1 & 41,8 & 0,03 & 75,8 \\
\hline 1656 & 16 & 500 & 6 & 57,6 & 42,3 & 0,03 & 75,6 \\
\hline 2442 & 24 & 400 & 2 & 56,5 & 43,4 & 0,03 & 75,8 \\
\hline 2444 & 24 & 400 & 4 & 57,9 & 42,0 & 0,04 & 75,5 \\
\hline 2446 & 24 & 400 & 6 & 58,7 & 41,2 & 0,03 & 75,6 \\
\hline 2452 & 24 & 500 & 2 & 57,3 & 42,6 & 0,03 & 75,8 \\
\hline 2454 & 24 & 500 & 4 & 57,4 & 42,5 & 0,03 & 75,7 \\
\hline 2456 & 24 & 500 & 6 & 57,6 & 42,3 & 0,03 & 75,8 \\
\hline
\end{tabular}


Após os testes experimentais amostras foram caracterizadas quimicamente, sendo que os resultados apresentaram uma porcentagem muito elevada de fluoreto de uranilo $\left(\mathrm{UO}_{2} \mathrm{~F}_{2}\right)$, em torno de $40 \%$, desqualificando $\mathrm{o}$ produto para uma posterior redução a urânio metálico.

Posteriormente, verificou-se na literatura consultada[51] que a simples presença de $\mathrm{UO}_{3}$ e/ou $\mathrm{U}_{3} \mathrm{O}_{8}$ em $\mathrm{UO}_{2}$ refletirá diretamente no $\mathrm{UF}_{4}$ resultando a formação de $\mathrm{UO}_{2} \mathrm{~F}_{2}$, um produto indesejável, principalmente para o $\mathrm{UF}_{4}$ destinado à preparação de urânio metálico.

A solução encontrada foi a preparação de um $\mathrm{UO}_{2}$ apropriado para obtenção de $\mathrm{UF}_{4}$ (tetrafluoreto de urânio). Em uma etapa inicial, foi realizada a decomposição térmica do $\left(\mathrm{NH}_{4}\right)_{2} \mathrm{U}_{2} \mathrm{O}_{7}$ (diuranato de amônio - DUA) a $300^{\circ} \mathrm{C}$, na presença de ar, resultando em $\cup_{3}$ (trióxido de urânio), segundo a reação:

$\left(\mathrm{NH}_{4}\right)_{2} \mathrm{U}_{2} \mathrm{O}_{7} \rightarrow 2 \mathrm{UO}_{3}+2 \mathrm{NH}_{3}+\mathrm{H}_{2} \mathrm{O}$

Posteriormente, $\mathrm{o} \mathrm{UO}_{3}$ obtido foi reduzido a $\mathrm{UO}_{2}$ em uma temperatura de aproximadamente $700^{\circ} \mathrm{C}$, utilizando-se hidrogênio como agente redutor:

$\mathrm{UO}_{3}+\mathrm{H}_{2} \rightarrow \mathrm{UO}_{2}+\mathrm{H}_{2} \mathrm{O}$

Amostras do $\mathrm{UO}_{2}$ produzido foram analisadas por difração de raios $x$ e por volumetria e gravimetria, para comprovar a formação do composto e verificar a porcentagem de urânio total e relação $\mathrm{O} / \mathrm{U}$. Os resultados confirmaram que o $\mathrm{UO}_{2}$ possuia propriedades adequadas para a preparação de $\mathrm{UF}_{4}$, sendo que 0 mesmo apresentou $87,4 \%$ de urânio total com 2,07 de relação O/U e estrutura típica, conforme demonstrado no difratograma de raios X (FIG. 11), comprovado pela carta JCPDS 41-1422 do catálogo da Powder Diffraction File [57]. 


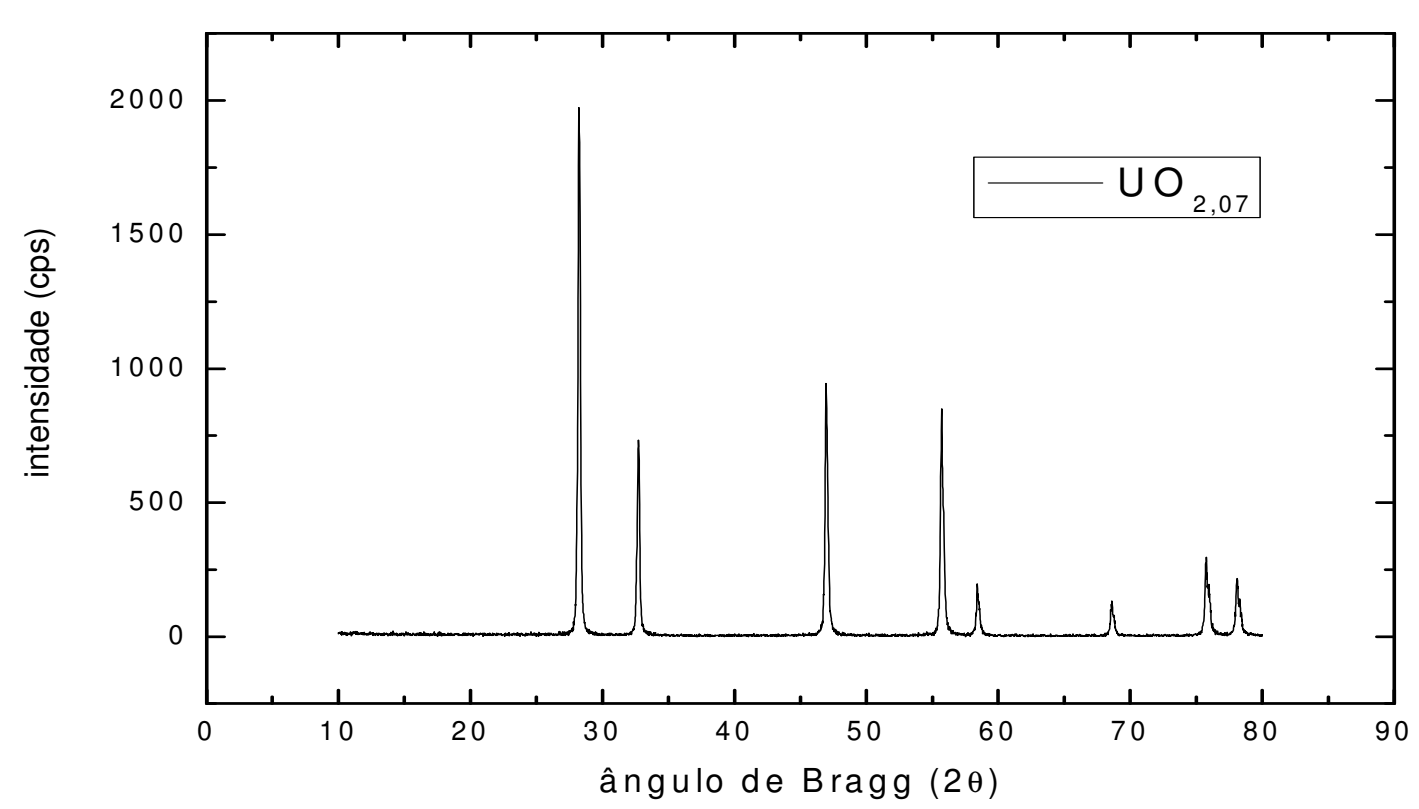

Figura 11 - Difratograma de raios x, típico do dióxido de urânio $\left(\mathrm{UO}_{2}\right)$

Para a preparação do $\mathrm{UF}_{4}$, utilizou-se um procedimento intermediário em relação aos ensaios anteriores, ou seja, fluoração por 12 horas a $150^{\circ} \mathrm{C}$ e decomposição a $400^{\circ} \mathrm{C}$ por 2 horas em atmosfera de argônio.

$\mathrm{O} \mathrm{UF}_{4}$ obtido foi caracterizado, sendo que apresentou um difratograma de raios $x$ típico, mas na análise química, ainda encontrou-se uma porcentagem relativamente alta de $\mathrm{UO}_{2} \mathrm{~F}_{2}$, em torno de $18 \%$, como podemos verificar na TAB. 12.

Uma nova tentativa foi realizada, aumentando-se o tempo de fluoração para 36 horas, mas os resultados foram semelhantes, tornando-se injustificável a permanência por longas horas em fluoração.

Tabela 12-Ensaios de fluoração e decomposição visando obtenção de $\mathrm{UF}_{4}$ via $\mathrm{UO}_{2}$

\begin{tabular}{|c|c|c|c|c|c|c|c|}
\hline \multirow{2}{*}{$\begin{array}{l}\text { IDENTIFICAÇÃO } \\
\text { AMOSTRA }\end{array}$} & \multirow{2}{*}{$\begin{array}{c}\text { FLUORAÇÃO } \\
\text { (horas) }\end{array}$} & \multirow{2}{*}{$\begin{array}{c}\text { TEMPERATURA } \\
\text { DECOMPOSIÇÃO } \\
\left({ }^{\circ} \mathrm{C}\right)\end{array}$} & \multirow{2}{*}{$\begin{array}{l}\text { TEMPO } \\
\text { DECOMPOSIÇÃo } \\
\text { (horas) }\end{array}$} & \multicolumn{4}{|c|}{ ELEMENTO - COMPOSTO (\%) } \\
\hline & & & & $\mathrm{UF}_{4}$ & $\mathrm{UO}_{2} \mathrm{~F}_{2}$ & $\mathrm{UO}_{2}$ & $\mathbf{U}_{\text {TOTAL }}$ \\
\hline 1242 & 12 & 400 & 2 & 80,7 & 18,1 & 0,04 & 74,6 \\
\hline $1242 \mathrm{~L}$ & 12 & 400 & 2 & 97,2 & 2,7 & 0,04 & 74,8 \\
\hline 3642 & 36 & 400 & 2 & 83,2 & 16,0 & 0,06 & 74,3 \\
\hline
\end{tabular}


Do material obtido após fluoração por 12 horas a $150^{\circ} \mathrm{C}$, retirou-se $50 \mathrm{~g}$ que passou por três lavagens com $150 \mathrm{~mL}$ de água destilada, após repouso retirou-se o sobrenadante e o material foi seco em estufa a $90^{\circ} \mathrm{C}$. Retirou-se duas amostras para difração: antes da lavagem $\left(\mathrm{NH}_{4}\right)_{7} \mathrm{U}_{6} \mathrm{~F}_{31}$, e após lavagem $\left(\mathrm{NH}_{4}\right)_{7} \mathrm{U}_{6} \mathrm{~F}_{31}-\mathrm{L}$. O restante do $\left(\mathrm{NH}_{4}\right)_{7} \mathrm{U}_{6} \mathrm{~F}_{31}-\mathrm{L}$ foi para decomposição a $400^{\circ} \mathrm{C}$ por 2 horas em atmosfera de argônio 5.0. Do $\mathrm{UF}_{4}$ resultante retirou-se uma amostra para análise química $\left(\mathrm{UF}_{4} 1242-\mathrm{L}\right)$. Os resultados foram apresentados na TAB. 12.

Após uma revisão da bibliografia disponível[28,51,52,53,54], concluiuse que uma alternativa seria realizar a etapa de fluoração em sistema aberto, portanto providenciou-se um bote de inconel, onde depositou-se a mistura com $100 \mathrm{~g}$ de $\mathrm{UO}_{2}$ e $80 \mathrm{~g}$ de $\mathrm{NH}_{4} \mathrm{HF}_{2}$ e colocou-se na estufa a $150^{\circ} \mathrm{C}$, onde permaneceu por 12 horas. Do material resultante, levou-se para a decomposição $50 \mathrm{~g}$ após lavagem com $\mathrm{H}_{2} \mathrm{O}$ destilada (1242AL) e $50 \mathrm{~g}$ sem lavagem (1242A). A decomposição foi realizada a $400^{\circ} \mathrm{C}$ por 2 horas em atmosfera de argônio. Os resultados da análise química podem ser verificados na TAB. 13.

Tabela 13 - Ensaios de fluoração e decomposição - sistema aberto - UF ${ }_{4}$ via $\cup_{2}$

\begin{tabular}{|c|c|c|c|c|c|c|c|}
\hline \multirow{2}{*}{$\begin{array}{c}\text { IDENTIFICAÇÃO } \\
\text { AMOSTRA }\end{array}$} & \multirow{2}{*}{$\begin{array}{l}\text { FLUORAÇÃO } \\
\text { (horas) }\end{array}$} & \multirow{2}{*}{$\begin{array}{c}\text { TEMPERATURA } \\
\text { DECOMPOSIÇÃo } \\
\left({ }^{\circ} \mathrm{C}\right)\end{array}$} & \multirow{2}{*}{$\begin{array}{l}\text { TEMPO } \\
\text { DECOMPOSIÇÃO } \\
\text { (horas) }\end{array}$} & \multicolumn{4}{|c|}{ ELEMENTO - COMPOSTO (\%) } \\
\hline & & & & $\mathrm{UF}_{4}$ & $\mathrm{UO}_{2} \mathrm{~F}_{2}$ & $\mathrm{UO}_{2}$ & $\mathbf{U}_{\text {TOTAL }}$ \\
\hline $1242 \mathrm{~A}$ & 12 & 400 & 2 & 90,6 & 8,21 & 0,03 & 74,4 \\
\hline $1242 \mathrm{AL}$ & 12 & 400 & 2 & 98,69 & 1,27 & 0,04 & 74,9 \\
\hline
\end{tabular}

O UF 4 obtido a partir da amostra 1242AL apresentou ótimos resultados na análise química.

Em todos experimentos realizados observou-se uma concentração de $\mathrm{UO}_{2}$ no $\mathrm{UF}_{4}$ muito abaixo dos limites especificados, portanto concluiu-se que a reação de fluoração foi extremamente eficiente, resolveu-se realizar outros testes com o objetivo de verificar o menor tempo necessário para uma fluoração efetiva do $\mathrm{UO}_{2}$. Os resultados são demonstrados na FIG. 12 : 


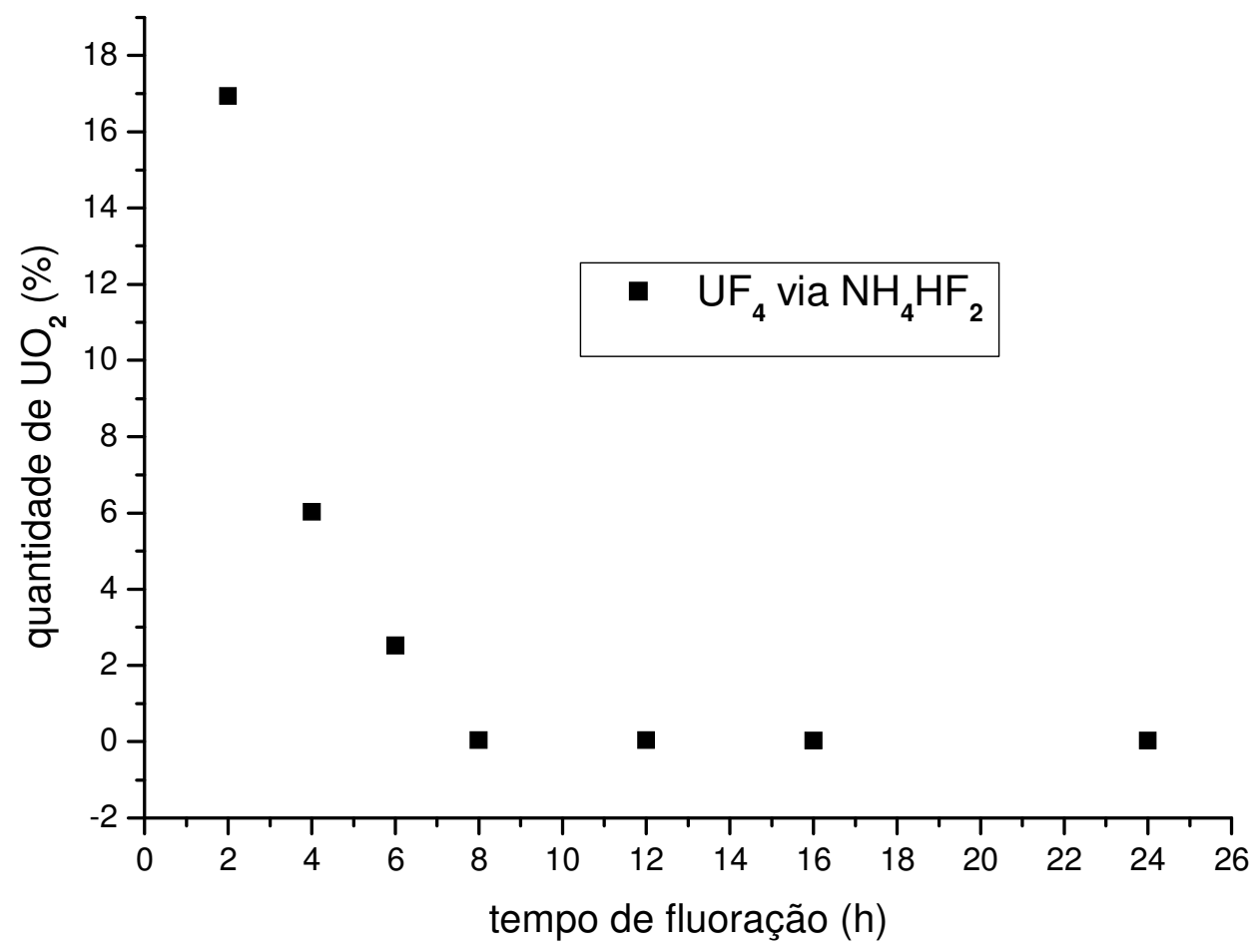

Figura 12 - Influência do tempo de fluoração na porcentagem de $\mathrm{UO}_{2}$ não convertido.

Em função dos resultados obtidos, pode-se observar no gráfico representado na FIG. 12, que o tempo mínimo necessário para uma reação de fluoração completa é de 8 horas. Tempos menores resultam em um $\mathrm{UF}_{4}$ com alta concentração de óxidos de urânio não convertidos, insolúveis em solução aquosa de oxalato de amônio. Tempos maiores são injustificáveis, acima de 8 horas em fluoração o rendimento da reação permanece estável, apresentando em média $0,04 \%$ de $\mathrm{UO}_{2}$ no $\mathrm{UF}_{4}$ obtido.

A TAB. 14 apresenta as densidades aparentes solta e batida de amostras de $\mathrm{UF}_{4}$ preparadas em condições diversificadas em relação ao tempo de fluoração, temperatura e tempo de decomposição. 
Tabela 14 - Variação da densidade em função das variáveis do processo.

\begin{tabular}{|c|c|c|c|c|c|}
\hline \multirow{2}{*}{$\begin{array}{l}\text { IDENTIFICAÇÃO } \\
\text { AMOSTRA }\end{array}$} & \multirow{2}{*}{$\begin{array}{c}\text { TEMPO } \\
\text { FLUORAÇÃo } \\
\text { (horas) }\end{array}$} & \multirow{2}{*}{$\begin{array}{c}\text { TEMPERATURA } \\
\text { DECOMPOSIÇÃo } \\
\left({ }^{\circ} \mathrm{C}\right)\end{array}$} & \multirow{2}{*}{$\begin{array}{l}\text { TEMPO } \\
\text { DECOMPOSIÇÃo } \\
\text { (horas) }\end{array}$} & \multicolumn{2}{|c|}{ DENSIDADE APARENTE $\left(\mathrm{g} \cdot \mathrm{cm}^{-3}\right)$} \\
\hline & & & & Solta & Batida \\
\hline 642AL & 6 & 400 & 2 & 0,91 & 1,28 \\
\hline 842AL & 8 & 400 & 2 & 1,00 & 1,43 \\
\hline 854 & 8 & 500 & 4 & 0,96 & 1,28 \\
\hline 1242AL & 12 & 400 & 2 & 0,98 & 1,43 \\
\hline 1656 & 16 & 500 & 6 & 0,98 & 1,28 \\
\hline 2442 & 24 & 400 & 2 & 0,98 & 1,43 \\
\hline 2456 & 24 & 500 & 6 & 0,98 & 1,25 \\
\hline 3642 & 36 & 400 & 2 & 1,00 & 1,41 \\
\hline
\end{tabular}

Anteriormente, verificou-se que o $\mathrm{UF}_{4}$ destinado à preparação do urânio metálico, deve ter densidade aparente suficientemente alta, recomendando-se que a densidade solta seja maior que $1 \mathrm{~g} . \mathrm{cm}^{-3}$. As densidades aparentes solta e batida, não sofreram variações significativas em função das variáveis do processo. A partir de 8 horas de fluoração e em todas condições de temperatura e tempo de decomposição, o UF $\mathrm{F}_{4}$ obtido em média uma densidade solta de 0,98 g. $\mathrm{cm}^{-3}$ e densidade batida de $1,36 \mathrm{~g} . \mathrm{cm}^{-3}$. Neste caso as densidades aparentes obtidas estão muito mais relacionadas ao processo de obtenção do $\mathrm{UF}_{4} \mathrm{e}$ não de suas variáveis.

Para confirmar a temperatura mínima necessária para uma decomposição completa do $\left(\mathrm{NH}_{4}\right)_{7} \mathrm{U}_{6} \mathrm{~F}_{31}$ a $\mathrm{UF}_{4}$, foram realizados estudos complementares por meio de análise térmica diferencial com análise termogravimétrica simultânea, em amostras de $\left(\mathrm{NH}_{4}\right)_{7} \mathrm{U}_{6} \mathrm{~F}_{31}$ e UF $\mathrm{U}_{4}$. Os resultados podem ser verificados na FIG. 13. 


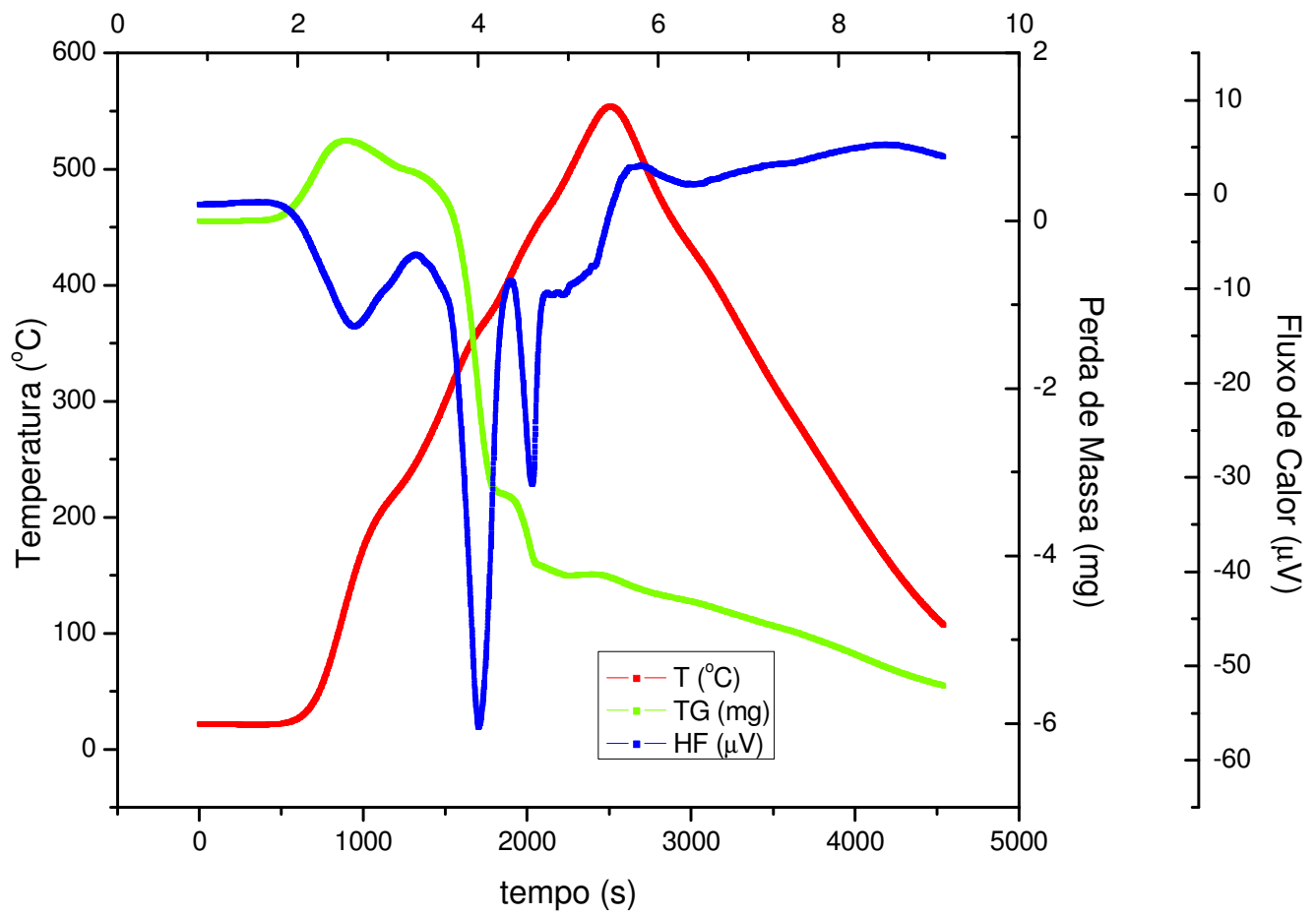

Figura 13 - Resultados de termogravimetria e análise térmica diferencial, amostras de $\left(\mathrm{NH}_{4}\right)_{7} \mathrm{U}_{6} \mathrm{~F}_{31}$.

Analisou-se primeiramente a perda de massa da amostra ao longo do período de realização do ensaio. A partir de uma massa inicial de 40,9 mg, observou-se ao final do período de aquecimento uma perda de massa de 4,22 mg, o que corresponde a $10,3 \%$ do total. Com a continuação do experimento durante o período de resfriamento, não houve estabilização do valor da perda de massa do sistema. A perda de massa final foi igual a $5,545 \mathrm{mg}$, correspondendo a $13,5 \%$, valor próximo ao teórico que é de 12,1\%. Isto indica que a liberação de massa por meio da reação de decomposição do $\left(\mathrm{NH}_{4}\right) \mathrm{U}_{6} \mathrm{~F}_{31}$ conforme equação (21) foi completa, levando à formação do $U_{4}$ puro. Conforme os resultados obtidos neste trabalho, observou-se perda de massa média de $20 \%$ após o processo de fluoração, de $11 \%$ após a lavagem e de 13\% após a reação acima.

A curva de fluxo de calor em função do tempo indica comportamento semelhante ao obtido pelo processo belga de decomposição de $\left(\mathrm{NH}_{4}\right) \mathrm{UF}_{5}$. Por comparação com os resultados de Van Impe [28], liberação primária de massa, 
devido à saída de amônia do sistema, ocorreria até $350^{\circ} \mathrm{C}$, com subseqüente liberação secundária de $\mathrm{NH}_{4} \mathrm{~F}$ até $500^{\circ} \mathrm{C}$. Neste trabalho, evidenciou-se que 0 evento de liberação primária ocorreu a $306^{\circ} \mathrm{C}$, com máximo a $360^{\circ} \mathrm{C}$, e que a liberação secundária iniciou-se a $407,4^{\circ} \mathrm{C}$, com máximo em $464,4^{\circ} \mathrm{C}$. Ambos os resultados confirmam a proximidade da técnica aqui utilizada com a de Van Impe [28], em termos de seus resultados principais. Entretanto, em adição aos resultados existentes previamente em literatura, com o auxílio das técnicas de análise térmica, determinou-se com maior precisão os valores de temperatura onde ocorrem os eventos principais na obtenção de UF4 via bifluoreto de amônio, estágio de decomposição de $\left(\mathrm{NH}_{4}\right)_{7} \mathrm{U}_{6} \mathrm{~F}_{31}$. Isto nos possibilita, caso seja necessário, a obtenção de valores ótimos de gastos de energia durante 0 processo.

\subsection{Caracterização do produto obtido}

O material obtido foi caracterizado química e fisicamente, empregandose as técnicas de difratometria de raios $X$, microscopia eletrônica de varredura (MEV) área de superfície específica por absorção gasosa (BET), diâmetro médio das partículas pelo método de espalhamento laser (CILAS) e massa específica por Picnometria de Hélio.

As características físico-químicas do $U F_{4}$ obtido via bifluoreto de amônio e do $U_{4}$ via aquosa, utilizado na produção rotineira do elemento combustível no IPEN-CNEN/SP[64], estão apresentadas na TAB. 15.

Tabela 15 - Características físicas e químicas do $\mathrm{UF}_{4}$.

\begin{tabular}{|c|c|c|}
\hline & UF $_{\mathbf{4}}$ via $\mathbf{S n C l}_{\mathbf{2}}$ & $\mathbf{U F}_{\mathbf{4}}$ obtido \\
\hline $\mathrm{UF}_{4}(\%)$ & 99,85 & 98,69 \\
\hline $\mathrm{UO}_{2} \mathrm{~F}_{2}(\%)$ & 0,34 & 1,27 \\
\hline $\mathrm{UO}_{2}(\%)$ & 0,29 & 0,04 \\
\hline Densidade aparente solta $\left(\mathrm{g} / \mathrm{cm}^{3}\right)$ & 2,12 & 0,86 \\
\hline Densidade aparente batida $\left(\mathrm{g} / \mathrm{cm}^{3}\right)$ & 2,65 & 1,19 \\
\hline Massa específica $\left(\mathrm{g} / \mathrm{cm}^{3}\right)$ & 6,70 & 6,60 \\
\hline Diâmetro médio da partícula $(\mu \mathrm{m})$ & 15,00 & 4,56 \\
\hline Área de superfície específica $\left(\mathrm{m}^{2} / \mathrm{g}\right)$ & 0,21 & 2,85 \\
\hline
\end{tabular}


Como se verificou anteriormente, quando o processo de redução for realizado sob maiores pressões e menores temperaturas, tolera-se até $4 \%$ de $\mathrm{UO}_{2}+\mathrm{UO}_{2} \mathrm{~F}_{2}$, que seriam reduzidos, portanto $0 \mathrm{UF}_{4}$ obtido atende à estas especificações.

$\mathrm{O} \mathrm{UF}_{4}$ obtido apresenta densidade aparente relativamente baixa, comparando-se com $\mathrm{UF}_{4}$ via aquosa, utilizado na produção rotineira do elemento combustível, porém, esse fator não será um problema, pois se trata de um processo alternativo que tem como maiores objetivos recuperar o urânio e os efluentes fluoretados gerados nos processos de reconversão do $U_{6}$, sendo que este $\mathrm{UF}_{4}$ será posteriormente diluído nos lotes de $\mathrm{UF}_{4}$ via aquosa produzidos no IPEN/CNEN-SP. Além disso, verifica-se que o UF 4 obtido apresenta uma área de superfície específica aproximadamente treze vezes maior que o $U F_{4}$ via aquosa, o que indica um pó muito mais reativo.

$\mathrm{Na}$ FIG. 14 apresentamos um difratograma de raios $\mathrm{x}$ típico, do $\mathrm{UF}_{4}$ obtido (via $\mathrm{NH}_{4} \mathrm{HF}_{2}$ ) e do $\mathrm{UF}_{4}$ via aquosa, que utiliza Cloreto de estanho II como agente redutor, comprovados pela carta JCPDS 32-1401 do catálogo da Powder Diffraction File [62].

Observa-se um difratograma com características semelhante ao obtido por via aquosa.

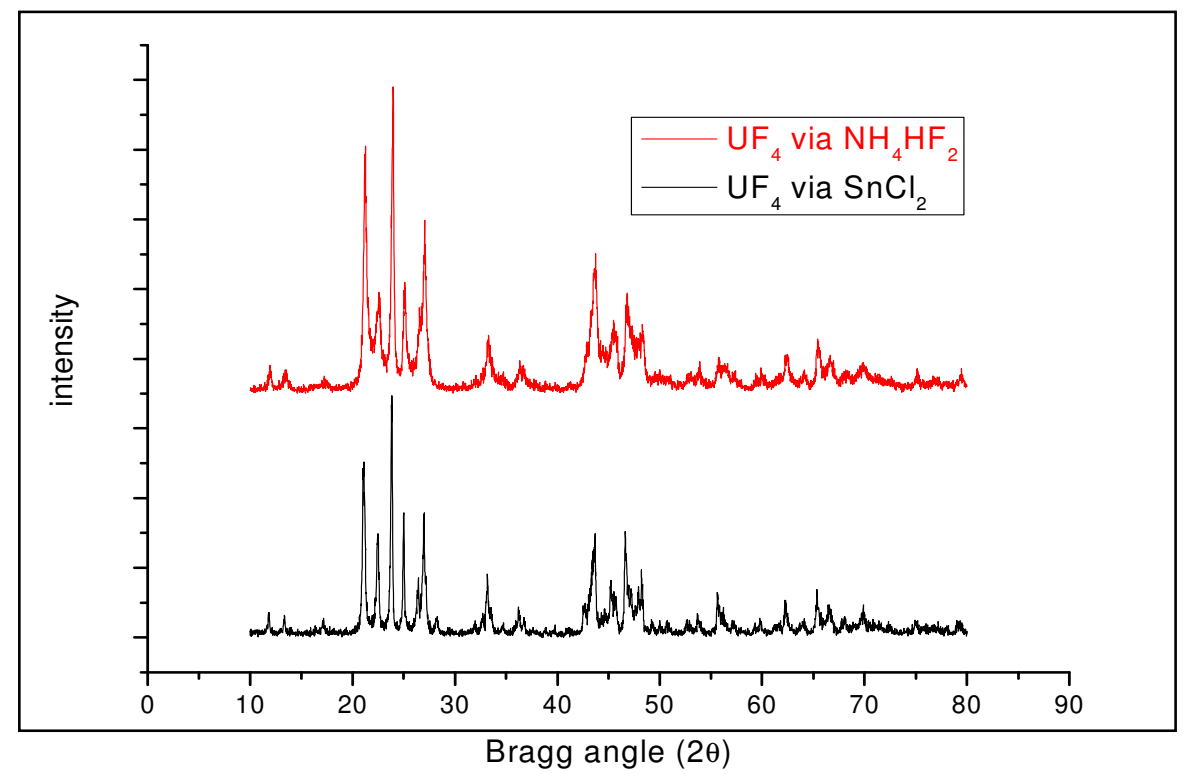

Figura 14 - Difratogramas de raios $\mathrm{x}$ do $\mathrm{UF}_{4}$ via bifluoreto e do $\mathrm{UF}_{4}$ via aquosa. 
Uma avaliação por microscopia eletrônica de varredura nos indicou uma estrutura granular e porosa como apresentado na FIG. 15.
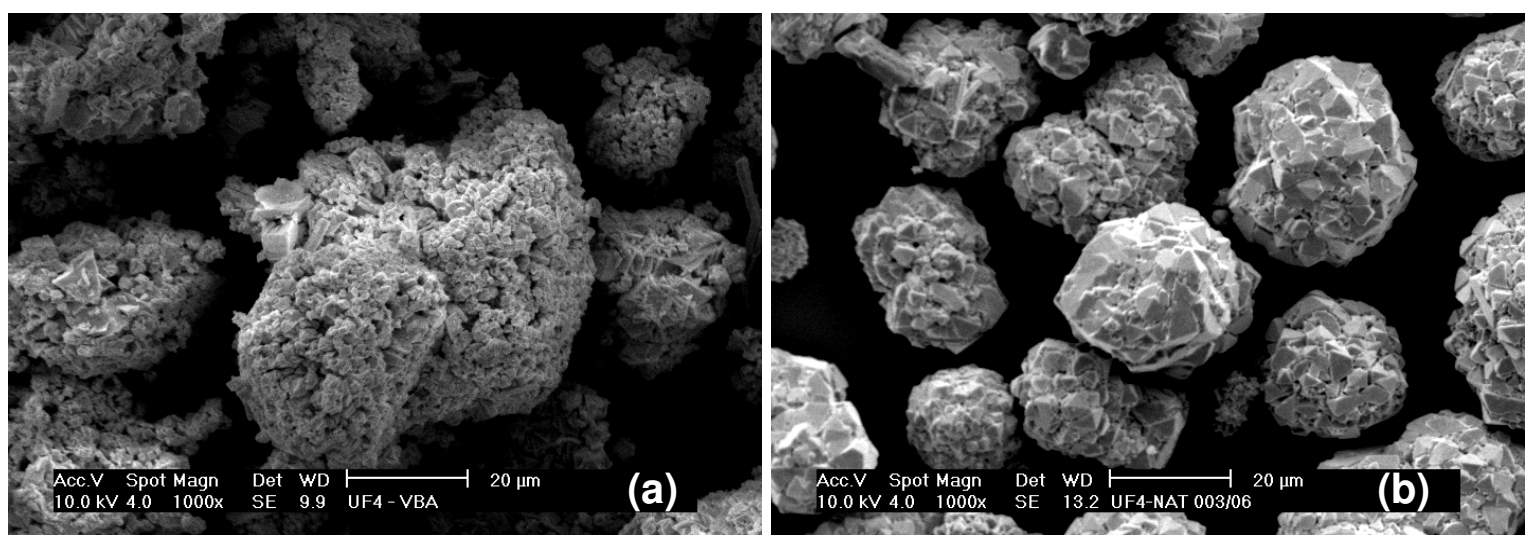

Figura 15 - Microscopia eletrônica de varredura do $\mathrm{UF}_{4}$ obtido via bifluoreto de amônia (a) e pela rota de $\mathrm{SnCl}_{2}$ (b)

$\mathrm{O} \mathrm{UF}_{4}$ via bifluoreto, apresenta aglomerados com tamanho médio das partículas aproximadamente três vezes menor que o $U_{F}$ via cloreto estanoso, em compensação possui uma área de superfície específica 13 vezes maior, provavelmente devido à grande porosidade observada.

Os resultados de análise química para determinação das impurezas, é apresentado na TAB. 16.

Tabela 16 - Impurezas determinadas no $\mathrm{UF}_{4}$ obtido.

\begin{tabular}{|c|c|}
\hline Elemento & $\mathbf{\mu g}^{-\mathbf{g}^{-1}}$ \\
\hline $\mathrm{Al}$ & 90 \\
\hline $\mathrm{Mn}$ & 10 \\
\hline $\mathrm{Fé}$ & 100 \\
\hline $\mathrm{Cr}$ & 15 \\
\hline $\mathrm{Ni}$ & 20 \\
\hline $\mathrm{Mo}$ & $<5$ \\
\hline $\mathrm{Cu}$ & $<5$ \\
\hline
\end{tabular}

Comparando às especificações limites apresentadas na TAB. 6, para o $\mathrm{UF}_{4}$ destinado à preparação de urânio metálico, verificamos a presença de ferro e alumínio acima do especificado. Porém, a pureza do $\mathrm{UF}_{4}$ obtido depende 
diretamente da pureza do $\mathrm{UO}_{2}$ utilizado na fluoração e sabendo que utilizaremos o $\mathrm{UO}_{2}$ proveniente da recuperação de placas, que durante o processo passa pela purificação por extração com solventes, este fator deixa ser um problema. 


\section{CONCLUSÕES}

Este trabalho mostrou que é perfeitamente viável a preparação de $\mathrm{UF}_{4}$, utilizando como meio de fluoração o bifluoreto de amônio, obtido a partir do efluente gerado na conversão do $U_{6}$ - TCAU - APOFU . O processo utilizado pode ser representado pelo diagrama da FIG. 16.

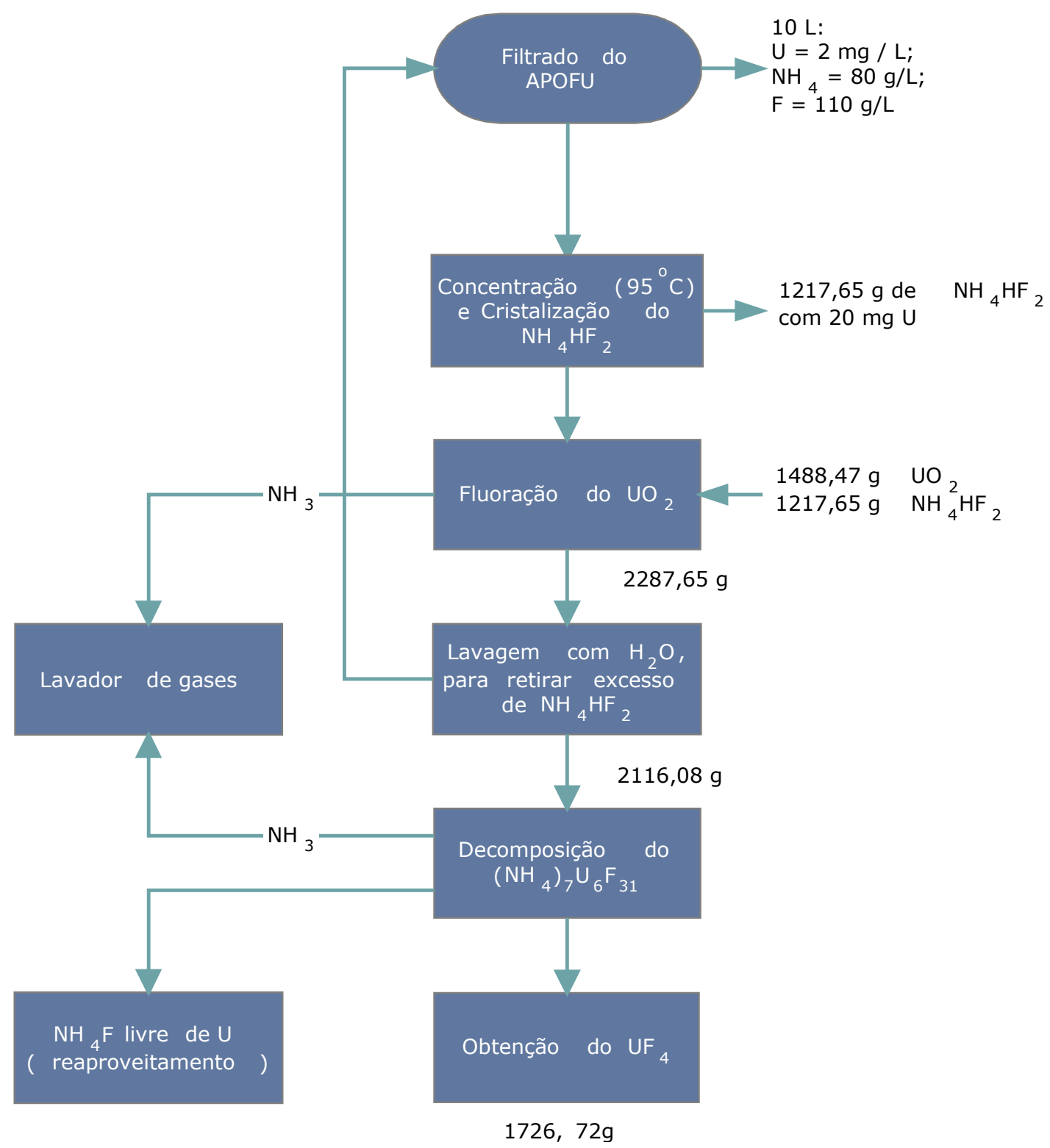

Figura 16 - Processo proposto para obtenção de $\mathrm{UF}_{4}$ a partir do filtrado VIII. 
A massa de $\mathrm{UF}_{4}$ obtida representa um rendimento muito próximo ao teórico, que é aproximadamente $1731 \mathrm{~g}$, quando partimos de $1488,4 \mathrm{~g}$ de $\mathrm{UO}_{2}$.

As melhores condições para obtenção de $\mathrm{UF}_{4}$ via bifluoreto de amônio, recomendadas neste trabalho são:

Temperatura de Fluoração $-150{ }^{\circ} \mathrm{C}$.

Tempo de fluoração -8 horas.

Temperatura de decomposição $-500{ }^{\circ} \mathrm{C}$.

Tempo de decomposição -2 horas.

$\mathrm{O} \mathrm{UF}_{4}$ obtido possui estrutura cristalina muito semelhante ao $\mathrm{UF}_{4}$ via aquosa produzido no IPEN/CNEN-SP, demonstrado nos difratogramas de raios $x$ apresentados. Além disso, tem composição química e características físicas adequadas para sua utilização na obtenção de urânio metálico. Apesar de apresentar densidade aparente relativamente baixa, esse fator não será um problema, pois se trata de um processo alternativo que tem como maiores objetivos recuperar o urânio e os efluentes fluoretados gerados nos processos de reconversão do $\mathrm{UF}_{6}$, sendo que este $\mathrm{UF}_{4}$ será posteriormente diluído nos lotes de $\mathrm{UF}_{4}$ via aquosa produzidos no IPEN/CNEN-SP.

O desenvolvimento deste processo não somente oferece um eficiente processo de recuperação de urânio e do fluoreto de amônio de fontes secundárias, por um caminho que elimina a poluição ambiental, mas também nos fornece um composto químico com características químicas e físicas muito semelhante ao já produzido rotineiramente do IPEN-CNEN-/SP.

O resultado nos permitiu a elaboração e envio de um trabalho ao INAC 2007 - International Nuclear Atlantic Conference, realizado no Brasil, em SantosSP, entre 30 de setembro e 5 de outubro de 2007. 


\section{TRABALHOS FUTUROS}

Serão realizados posteriormente ensaios de incorporação do UF4 obtido via bifluoreto de amônio ao UF4 utilizado na produção rotineira de elementos combustíveis (via $\mathrm{SnCl}_{2}$ ), na Divisão de Processos Químicos do CCN IPEN.

Uma sugestão para trabalhos futuros seria o estudo da implantação de um sistema eficiente na recuperação do fluoreto de amônio liberado na etapa de decomposição, livre de urânio. Este sal pode ser reutilizado no próprio processo, como pode ser usado no polimento e recobrimento de vidros, como antisséptico no preparo de cerveja, em impressão sobre têxteis e até mesmo como agente para proteção contra traças.

É importante futuramente, o estudo da viabilidade do reaproveitamento de outros efluentes gerados na Reconversão do $U_{6}$, ou seja, dos filtrados do DUA (antes ou após o tratamento) e do filtrado do UF $_{4}$, visando a recuperação do $\mathrm{NH}_{4} \mathrm{~F}$ e do urânio ainda contido. 


\section{REFERÊNCIAS BIBLIOGRÁFICAS}

1. GIORDANO, G. Tratamento e Controle de Efluentes industriais, 2005 Disponível em: www.ufmt.br/esa/Modulo II Efluentes industriais/. Acesso em 13 de dezembro de 2006.

2. ALMEIDA, J. R. MORAES, F.E. SOUZA, J.M e MALHEIROS, T.M. PLANEJAMENTO AMBIENTAL, 2ED. SÃO PAULO: THEX, 2002.

3. IBAMA. Diretrizes de pesquisa aplicada ao planejamento e gestão ambiental. Brasília: Ministério do Meio Ambiente, 1994.

4. PHILIPI JR., A.; ROMÉRO, M. A., BRUNA, G.C. - Uma introdução à questão ambiental: Curso de gestão ambiental, 1 ed. Manole, 2004.

5. MARTA, I.C.P.; TOCCHETTO, M.R.L. - Sistema de Gestão Ambiental. Disponível em

$<$ http://www.ambientebrasil.com.br/agenda/sistemagestao.htm>. Acesso em 07 de julho de 2005.

6. CALLENBACH, E. ; CAPRA,F.; GOLDMAN,L.,LUTZ,R. \& MARBUP. Gerenciamento ecológico - (Eco-Management): guia In: ELMWOOD de auditoria ecológica e negócios sustentáveis. São Paulo: Cultrix 1993, (IBEAM).

7. Tratamento de efluentes industriais. Disponível em <http://www.cimm.com.br/ cimm/construtordepaginas/htm/3245267.htm > Acesso em 10 de janeiro de 2006.

8. ALVES, I. C. Metodologia para apuração e controle de custos da qualidade ambiental. . 2001. Dissertação (Mestrado) - Universidade Federal de Santa Catarina, Florianópolis.

9. MOURA, L. A. Economia ambiental: gestão de custos e investimentos. São Paulo: [s.n.]. 2000. 
10. PORTAL ambiental: a indústria e o meio ambiente. Disponível em $<$ http://www.ambientebrasil.com.br/composer.php3?base=./gestao/index.ht

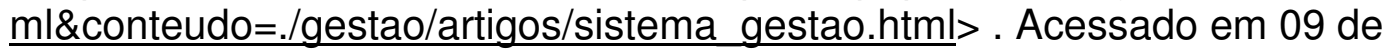
agosto de 2005.

11. GOLDEMBERGH, J.: BARBOSA, L. - A legislação ambiental no Brasil e em São Paulo. Revista Eco, n.21, v. 14, novembro 2004. Disponível em $<$ http://www.ambientebrasil.com.br/composer.php3?base=./gestao/index.ht

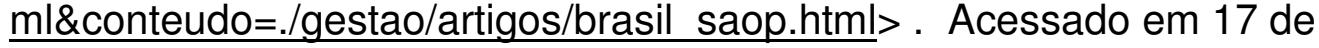
julho de 2005.

12. LAVORATO, M. L. A. - A importância da consciência ambiental para 0 Brasil e o Mundo - disponível em <http://www.ambientebrasil.com.br/composer.php3?base=./gestao/index.ht ml\&conteudo=./gestao/artigos/ma brasil.htm. Acesso em 10 de julho de 2005.

13. GOUVÊA, Y. M. G.; ACKER, F. T. V. Gestão e tecnologias ambientais: Legislação ambiental. São Paulo: USP, 2002. (MBA-USP "Programa de Educação Continuada").

14. BRASIL. Lei no 6.938, de 31 de agosto de 1981.Diário Oficial. Dispõe sobre a Política Nacional do Meio Ambiente, seus fins mecanismos de formulação e aplicação, e dá outras providências Ministério da Ciência e Tecnologia.

15. ABNT - Associação De Normas Técnicas. Sistemas de gestão ambiental: requisitos com orientações para uso.2 ed. Rio de Janeiro: ABNT, 2005 (NBR ISO 14001)

16. SICOLI, J.C.M. (coord). Legislação ambiental: textos básicos. São Paulo: IMESP, 2000. .884p. (Este volume complementa e atualiza a 2.ed. do v.2 da obra ). Manual prático da promotoria do meio ambiente (legislação).

17. LEGISLAÇÃO AMBIENTAL FEDERAL - Coletânea especialmente elaborada para o programa de Educação Continuada da Escola Politécnica da Universidade de São Paulo A1-017. São Paulo, 2002.

18. BRASIL. Constituição. Constituição da República Federativa do Brasil promulgada em 05 de outubro de 1988. 6 ed. São Paulo: Saraiva, 1992. 
19. SALVI, F. Técnicas de tratamento de efluentes industriais: apostila da Salvi Engenharia. São Paulo. 2000.

20. MACHADO, P.A.L. Direito Ambiental Brasileiro. 4. ed. São Paulo: Malheiros, 1992.

21. FARIA, N. G. M. DE. Aspectos jurídicos e institucionais dos rejeitos radioativos. Rio de Janeiro: 1996 Tese (Doutoramento) Universidade Federal do Rio de Janeiro.

22. COMISSÃO NACIONAL DE ENERGIA NUCLEAR. Diretrizes Básicas de Radioproteção. 01 de agosto de 1988 (CNEN - NE - 3.01).

23. COMISSÃO NACIONAL DE ENERGIA NUCLEAR. Gerência de Rejeitos Radioativos em Instalações Radioativas. 17 de dezembro de 1985 (CNEN - NE - 6.05).

24. COMISSÃO NACIONAL DE ENERGIA NUCLEAR. Licenciamento de Instalações Nucleares. 14 de dezembro de 1984 (CNEN - NE - 1.04).

25. PINTO, L. C. M. Quantikov - um analisador microestrutural para o ambiente Windows ${ }^{T M}$. São Paulo, 1996. Tese (Doutoramento) - Instituto de Pesquisas Energéticas e Nucleares.

26.INSTITUTO DE PESQUISAS ENERGÉTICAS E NUCLEARES. Implantação de um Centro de Processamento de Combustíveis no IPEN - Plano Diretor. Departamento do Ciclo do Combustível. Relatório Interno MC.PT.0001.97.0. São Paulo, 1997. 35p

27.SNELGROVE, J. L.; DOMAGALA, R. F.; HOFFMAN, G. L.; WIENCEK, T. C.; COPELAND, G. L.; HOBBS, R. W.; SENN, R. L. The use of $\boldsymbol{U}_{3} \mathrm{Si}_{2}$ dispersed in aluminum in plate-type fuel elements for research and test reactors. Argonne National Lab., Argonne, III., October 1987 (ANL/RERTR/TM-11).

28. VAN IMPE, J. D. Uranium and fabrication, Chemical Engineering Progress 50, May,1954 p.230-234. 
29. ESTEBAN DUQUE, A.; GISPERT BENARCH,M; Producción de $\boldsymbol{U F}_{\mathbf{4}}$ por reducción eletrolítica, Energia Nuclear, 1987, p.25

30. FRAJNDLICH, E.U.C. Estudo do tratamento químico da solução de fluoreto de amônio proveniente da unidade de reconversão de urânio. (Dissertação de mestrado, Instituto de Pesquisas Energéticas e Nucleares, Universidade de São Paulo), 1992.

31. Seneda, J.A.; Figueiredo, F.F.; Abrão, A.; Carvalho, F.M.S.; FRAJNDLICH, E.U.C. Recovery of uranium from the filtrate of ammonium diuranate prepared from uranium hexafluoride, Journal of Alloys and Compounds 323-324, 2001, pp. 838-841.

32. SANTOS, L.R. Unidade piloto de obtenção do tricarbonato de amônio e uranilo. São Paulo, (Dissertação de mestrado Instituto de Pesquisas Energéticas e Nucleares. Universidade de São Paulo), 1989.

33. CUSSIÓL, A.F. Tecnologia para a preparação de tetrafluoreto de urânio por Fluoretação de $\mathrm{UO}_{2}$ obtido a partir de diuranato de amônio. São Paulo, 1974. (Dissertação de mestrado, Escola Politécnica, Universidade de São Paulo).

34. AQUINO, A.F. Obtenção de Tetrafluoreto de urânio por via aquosa a partir do dióxido. (Dissertação de mestrado, Instituto de Pesquisas Energéticas e Nucleares, Universidade de São Paulo), 1995.

35. RIELLA, H.G. Especificação físico química do $\boldsymbol{U F}_{\mathbf{4}}$. Departamento do Ciclo do Combustível - IPEN. Relatório Interno. São Paulo, 2007.

36. GISRGIS,B.S.; ROFAIL,N.H.; Reactivity of various $\mathrm{UO}_{3}$ modifications in the fluorination to $U_{4}$ by Freon 12, J. of Nuclear Materials, 195(1992)p126.

37. GALKIN,N.P.;SUDARIKOW, B.N.; VERYATIN,U.D.; SHISHVOV,Yu.D.; MAIOROV,A.A. Technology of uranium. Jerusalem, Israel Program for Scientific Translations, 1966. cap. 11.

38. GMELIN, L. Gmelins Handbuch der Anorganischen Chemie. $8^{\mathrm{ed}}$ Berlin, Springer-Verlag, 1980. C-8. 
39. HARRINGTON, C.D. \& RUEHLE, E. Uranium production technology. New Jersey, van Nostrand, 1969.

40.KATZ, J.J. \& RABINOWITCH, E. The chemistry of uranium. Part 1. The elements, its binary and related componds. New york, McGraw-Hill, 1951.

41. MELLOR,J.W. Acomprehensive treatise on inorganic and theorical chemistry. London, Longmans, 1932. v. 12.

42.BOLTON, H.C. Bull.Soc.Chim.Paris,6(2):450, 1866 apud KAT,J.J. \& RABINOWITCH, Z. The chemistry of uranium. Part I. The element, its binary and related compounds. New York, McGraw-Hill, 1951. p.355.

43.BOLTON, H.C.; Z. Chem., 2(2):353, 1866 apud KAT,J.J. \& RABINOWITCH, Z. The chemistry of uranium. Part I. The element, its binary and related compounds. New York, McGraw-Hill, 1951. p.355.

44. ALFREDSON,P.G. Australian experiments in the production of yellow cake and uranium fluorides. In: INTERNATIONAL ATOMIC ENERGY AGENCY. Production of yellow cake and uranium fluorides: proceedings of an Advisory Group meeting..... held in Paris, June 5-8, 1979. Vienna,1980. p.149-78.

45. ALLEN,R.J.; PETROW,H.G.; MAGNO,P.J. Precipitation of uranium tetrafluoride from aqueos solution by catalytic reduction. Ind. Eng. Chem., 50(12): 1748-9,1958.

46. ALLEN,R.J.; PETROW,H.G.; MAGNO, P.J. Preparation of sense, metal grade uranium tetrafluoride from uraniferous ores, In: UNITED NATIONS. Peaceful uses of atomic energy:proceedins of the $2^{\text {nd }}$ international conference.... Held in Geneva, Sept. 1-13, 1958, v.4:Production of nuclear materials and isotopes. Geneva, 1958. p.121-4.

47. GISPERT BENACH,M.; HERNANDEZ ARROYO, F.; MONTES PONCE DE LEON, M.; ROJAS DE DIEGO, J.L. Obtención de UF $\boldsymbol{F}_{4}$ por reducción eletrolítica. I Estudios a escala de laboratorio. Energ. Nucl.(madrid0, 16(80) : 623-36, 1972. 
48. ESTEBAN DUQUE, A.; GISPERT BENACH,M.; HERNANDEZ ARROYO, F.; MONTES PONCE DE LEON, M.; ROJAS DE DIEGO, J.L. Producción de $U_{4}$ por reducción eletrolítica. II planta Piloto. Energ. Nucl.(madrid0, $17(82)$ : 113-21, 1973.

49.SCOTT,C.D.; ADAMS, J.B.; BRESEE, J.C. Fluorox process: production of $U F_{6}$ in fluidized bed reactor. Oak Ridge, TN, Oak Ridge National Lab., 1960. (ORNL - 2797).

50.VOGEL,G.L.; SANDUS, O.; STEUNENBERG, R.K.; MECHAM, W.J. Fluidized-bed techniques in producing uranium hexafluoride from ores concentrates. Ind. Eng, Chem., 50(12): 1744-7, 1958.

51. ASHBROOK,A.W. \& SMART,B.C. A review and update of refining pratice in Canada. In: INTERNATIONAL ATOMIC AGENCY. Production of yellow cake and uranium fluorides: proceedings od an Advisory Group meeting.... Held in Paris, June 5-8, 1079. Vienna, 1980. p.261-87.

52. MILLER,E.J. The reaction of uranium dioxide with hdrogen fluoride to produce uranium tetrafluoride. St. Louis. MO, Mallinckrodt Chemical Works, Apr. 1,1946. (MCW-24)

53. OPIE,J.V. The preparation of pure uranium tetrafluoride by a wet process. St. Louis. MO, Mallinckrodt Chemical Works, Apr. 1,1946. (MCW25)

54. LENAHAN,K.J. Eldorado wet way process. In: Uranium 82: $12^{\text {th }}$ annual hydrometallurgical meeting, held in Toronto, Aug. 29-Sept.1.1982

55. RIBAS, A.S, ABRÃO, A. Preparação de $\mathbf{U O}_{2}$ apropriado para obtenção de $\boldsymbol{U} \boldsymbol{F}_{4}$, Publicação IEA 318, 1973.

56. FILHO, C. A.; ABRÃO, A.; Tecnologia para preparação de tetrafluoreto de urânio por fluoridretação de $\mathrm{UO}_{2}$ obtido de diuranato de amônio, Publicação 379 - IEA 1975.

57. INSTITUTO DE PESQUISAS ENERGÉTICAS E NUCLEARES/COMISSÃO NACIONAL DE ENERGIA NUCLEAR. Determinação de urânio em efluentes de tricarbonato de amônio e uranilo por voltametria de gota pendente de mercúrio. (IPEN - QI - 056). 
58. FEDERGRÜN, L., ABRÃO, A. Determinação dos conteúdos de $\mathrm{UO}_{2} \mathrm{~F}_{2}$, de $\mathrm{UO}_{2}$ e $\mathrm{UF}_{4}$ em tetrafluoreto de urânio. São Paulo, Instituto de Energia Atômica, maio 1974. (IEA - Publicação 341).

59. INSTITUTO DE PESQUISAS ENERGÉTICAS E NUCLEARES/COMISSÃO NACIONAL DE ENERGIA NUCLEAR. Determinação dos ânions cloreto e fluoreto em compostos de urânio por eletrodos seletivos de íons. (IPEN - QI - 049).

60. INSTITUTO DE PESQUISAS ENERGÉTICAS E NUCLEARES. Determinação da densidade (massa específica) dos pós de urânio, via picnometria de Hélio. Departamento do Ciclo do Combustível. Relatório Interno IT.CCN.10.122.08-00. São Paulo, 2001. 5p.

61. INSTITUTO DE PESQUISAS ENERGÉTICAS E NUCLEARES/COMISSÃO NACIONAL DE ENERGIA NUCLEAR. Determinação das densidades aparentes solta e batida de amostras sólidas na forma de pó. (IPEN QI-045).

62.JCPDS INTERNATIONAL CENTRE FOR DIFRACTION, Powder Diffraction File, Inorganic Compounds, 1978.

63. Ficha de informações do Bifluoreto de amônio. Disponível em http://www.brazmo.com.br/fispq/Bifluoreto de Am\%C3\%B4nio.pdf Acessado em agosto de 2005.

64. Frajndlich,E.U.C. Saliba-Silva, A.M., Zorzetto, M.A.; "Alternative Route for UF $_{6}$ Conversion Towards UF to $_{4}$ Produce Metallic Uranium", $21^{\text {st }}$ international Meeting on Reduced Enrichment for Research and Test Reactors (RERTR), São Paulo/Brazil,1998. 